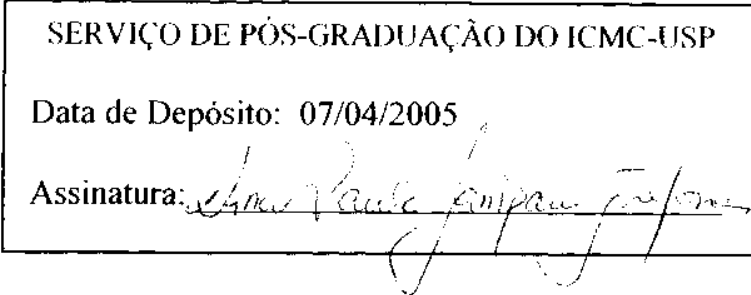

\title{
Seleção de características em SVMs aplicadas a dados de expressão gênica
}

Bruno Feres de Souza

Orientador: Prof. Dr. André Carlos Ponce de Leon Ferreira de Carvalho

Dissertação apresentada ao Instituto de Ciências Matemáticas e de Computação - ICMC-USP, como parte dos requisitos para obtenção do título de Mestre em Ciências de Computação e Matemática Computacional.

USP - São Carlos

Abril $/ 2005$ 
Aluno: Bruno Feres de Souza

A Comissão Julgadora:

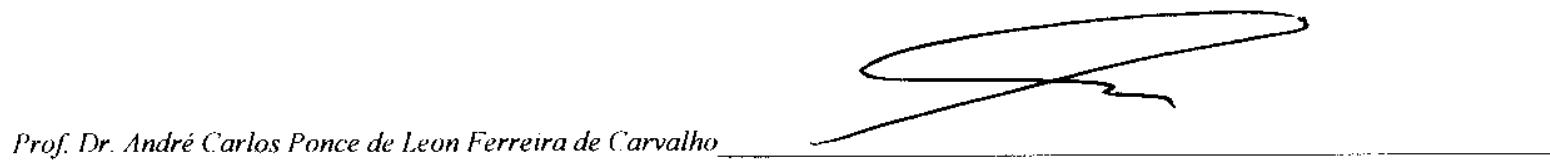

Prof. Dr. Alexandre Claudio Botazzo Delbem

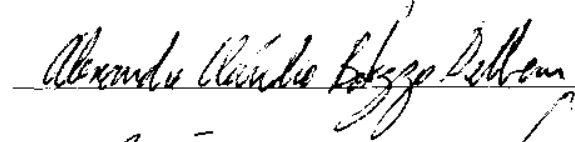

Prof. Dr. Roberto Marcondes Cesar Junior

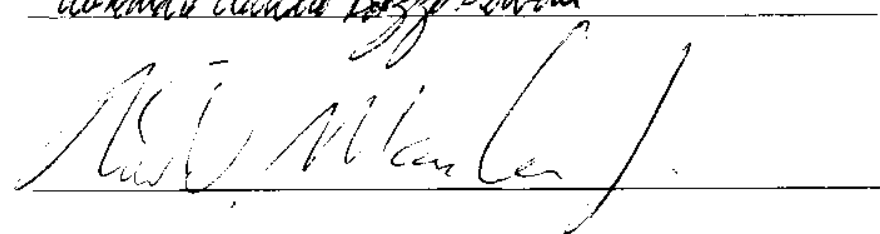




\section{Agradecimentos}

Agradeco, primeiramente, a Deus por tudo o, em especial. pelas oportunidades que me tem concedido e pelas pessoas que tem posto em men caminho.

Agradeço a mous pais e irmãos por, mesmo longe, estarem sempre comigo. Por scu apoio, anor anizade conselhos e dedicação. São eles que, diariamente, acreditam em mim o me ajudan a superar as dificuldacles. Muito obrigado!

Agradeco ao Prof. André. mell orientador nesta jomada, por nunca me deixar desanimar e por ter ensinado através do exemplo. o que ó ser um bom pesquisador (não que en tenha aprendido completanente, mas en tento). Son grato por sna infuita paciencia e comprensão. Certanente, ele é agora parte importante de mim e do que vou ser.

Durante o mestrado, fir novas anizades e fortaleci antigas. Hoje on me considero unn pessoa melhor por cansa desses amigos. Especialmente, sou grato a Femando, que concordon enn cleixar a sempre saudosa São Luís e vir estudar en São Carlos. É uma pessoa que en admiro profundanente. Ele foi, é, meu companheiro en todos os momentos, felizes on nem tanto. Valeu!

Várias outras pessoas fizcram a diferença e agradeço muitíssimo por tê-las conhecido. Sou grato à Jac, ao Leo Killer. ao Popi, ao Eduardão, ao Daniboy, ao Nilson, ao Cesár. ao Waldo, ao Jemr, an Fodra, an Rodrigo, ao Balan, no Magoo, ao Arriano, à Cris, à Karren. ao Japar ao Mareclo, ao Douglas, ao Robertão, ao Camillo, c a mulutos outros annigos, por cutarem sempre comigo.

Agradeço a todos os professores e funcionários do ICVIC, por tudo gue cu aprendi e. por estarem sempre dispostos a ajudar.

Agradeco à CAPES, polo suporte financeiro essencial a cste trabalho. 


\section{Resumo}

Recentemente, diversas tecnologias de análise de expressão gênica têm sido introduzidas. Os miroarrays estão entre as mais utilizadas. Dentre suas aplicações mais comuns, podese destacar a classificação de amostras de tecido, essencial para a identificação correta do tipo de câncer. Esta classificação é realizada com a ajuda de algoritmos de AMáquina (AM), como as Máquinas de Vetores de Suporte, ou simplesmente SVMs. Uma particularidade dos dados de expressão gênica é que a quantidade de amostras utilizadas pelo algoritmo de aprendizado é, normalmente, muitas vezes inferior à quantidade de características consideradas, o que pode deteriorar o desempenho dos algoritmos do AM e dificultar a compreensão dos dados. Neste contexto, o presente trabalho visa à comparação de diversas técnicas de seleção de características (SC) cm SVMs aplicadas a dados microarrays. Além disso, durante a pesquisa, foram desenvolvidas 2 novas técnicas de SC baseadas em algoritmos genéticos. Os experimentos demonstram que a maioria das técnicas testadas ć capaz de reduzir sobremaneira a dimensionalidade dos dados de expressão gênica sem prejudicar o desempenho das SVMs. 


\section{Abstract}

Recently, a lot of large scale gene expression analysis technologies have been introducted Microarrays are among the most used ones. Among their most common applications, one can highlight the classification of tissue samples, which is essential to the correct identification of the cancer type. This classification is carried out by Machine Learning (ML) algorithms, like the Support Vector Machines (SVMs). Gere expression data are characterized by an disproportionate rate between the number of tissue samples and the dimensionality of the domain, which can hurt the performance of the ML algorithms. In this context, the present work wish to compare several feature selection techniques in SVMs applied to microarray data. Besides, during this research, 2 new techniques based on genetic algorithms for selecting genes were developed. The experiments showed that most of the tested techniques was able to gratefully reducc the dimensionality of the gene expression data without degradation of SVM performance. 


\section{Sumário}

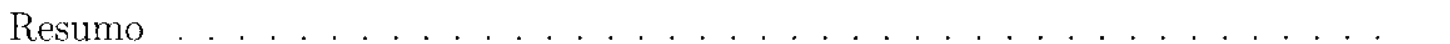

Abstract ........................ . . . . . . . . . . . .

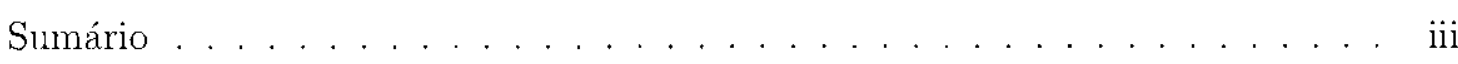

Lista de Figuras . . . . . . . . . . . . . . . . . . . . . . . v

Lista de Tabelas ... . . . . . . . . . . . . . . . . . . ix

1 Introdução 1

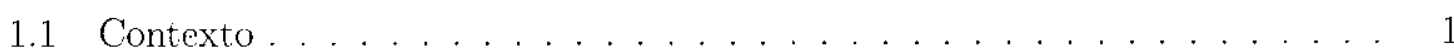

1.2 Motivação . . . . . . . . . . . . . . . . . . . 3

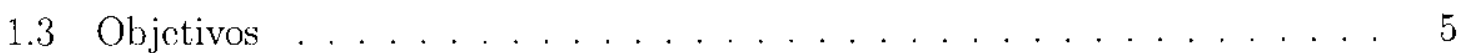

1.4 Organização da dissertação . . . . . . . . . . . . . . . 6

2 Análise de Expressão Gênica $\quad 7$

2.1 Considerações Iniciais . . . . . . . . . . . . . . . . . . . . . . 7

2.2 Conceitos biológicos . . . . . . . . . . . . . . . . . . 7

2.2 .1 Células . . . . . . . . . . . . . . . . . 7

2.2 .2 Cromossomos, DNA e genes ................ 9

2.2 .3 Proteínas e expressão gênica . . . . . . . . . . . . . . . . . 10

2.3 Técnicas de Análise do Expressão Gênica . . . . . . . . . . . . . . . . . . 12

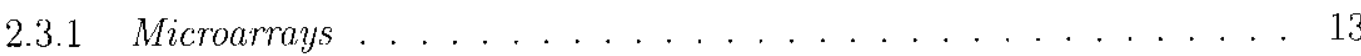

2.3.2 Serial Analysis of Gene Expression-SAGE . . . . . . . . . . . 18

2.3.3 Massive Parallel Signature Sequencing-MPSS . . . . . . . . . 19

2.4 Considerações finais . . . . . . . . . . . . . . . . . . . . . . 20

3 Máquinas de Vetores de Suporte 22

3.1 Considerações Iniciais . . . . . . . . . . . . . . . . . . . . . . . . . 22 
3.2 Teoria do Aprendizado Estatístico . . . . . . . . . . . . . . 23

3.3 Máquinas de Vetores de Suporte . . . . . . . . . . . . . . . . . 26

3.3.1 SVMs Lineares para Dados de Classes Linearmente Separáveis . . . 26

3.3.2 SVMs Lineares para Dados de Classes Não-linearmente Separáveis . 31

3.3 .3 SVMs Não-lineares . . . . . . . . . . . . . . . . . . . 34

3.4 Considerações Finais . . . . . . . . . . . . . . . . . . . 36

4 Seleção de Características em Dados de microarray $\quad 37$

4.1 Considerações Iniciais . . . . . . . . . . . . . . . . . . . . . . . 37

4.2 O Problema da Seleção de Características . . . . . . . . . . . . . 38

4.3 Características dos Algoritmos de SC . . . . . . . . . . . . . 40

4.3.1 Ponto(s) de Início da Busca e Geração dos Subconjuntos . . . . . . 41

4.3 .2 Estratégia da Busca . . . . . . . . . . . . . . . 41

4.3 .3 Estratégia de Avaliação . . . . . . . . . . . . . . . . . . . . 42

4.3 .4 Critério de Parada . . . . . . . . . . . . . . . . 43

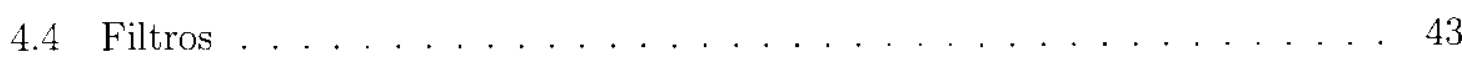

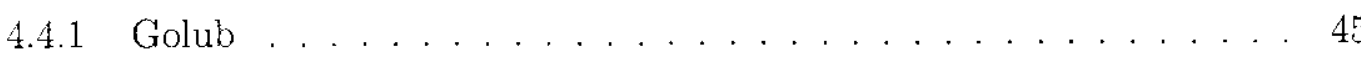

4.4.2 Threshold Number of Misclassification-TNoM . . . . . . . . 46

4.4 .3 Info . . . . . . . . . . . . . . . . 46

4.4 .4 Taxa de Ganho . . . . . . . . . . . . . . . . . . 48

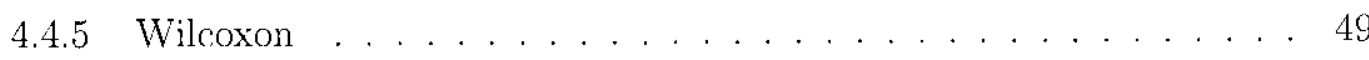

4.4 .6 ReliefF ......................... . . . 50

4.4.7 Correlation-Based Feature Selection-CFS . . . . . . . . . . . . . 51

4.4 .8 Filtro de Consistência . . . . . . . . . . . . . . 52

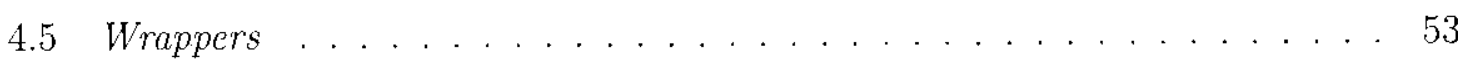

4.5.1 Recursive Feature Elinination-RFE . . . . . . . . . . . . 55

4.5.2 Approximation of the zero-norm Minimization - AROM . . . . . . 56

4.6 Algoritmos Genćticos para Seleção de Genes . . . . . . . . . . . . . . . 57

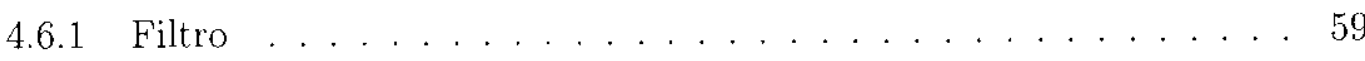

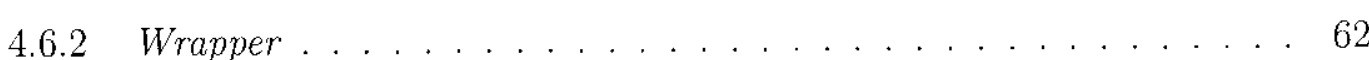

4.7 Considerações Finais . . . . . . . . . . . . . . . . . . . . . 64 
5 Experimentos $\quad 65$

5.1 Considerações Iniciais . . . . . . . . . . . . . . . . . . 65

5.2 Metodologia . . . . . . . . . . . . . . . . . . . . 65

5.2 .1 Descrição Geral . . . . . . . . . . . . . . . . . . . . 65

5.2 .2 Teste estatístico . . . . . . . . . . . . . . . 67

5.2 .3 Métodos e seus parâmetros . . . . . . . . . . . . . . . 68

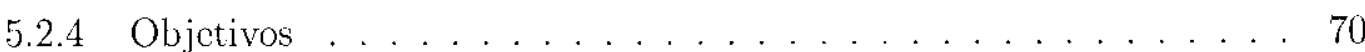

5.3 Bases de dados . . . . . . . . . . . . . . . . . . . 71

5.4 Resultados Experimentais . . . . . . . . . . . . . . 73

5.4 .1 Leucemia . . . . . . . . . . . . . . . . . . . . 74

5.4 .2 Linfoma . . . . . . . . . . . . . . . . . 76

5.4 .3 Cólon . . . . . . . . . . . . . . . . . . . 77

5.4 .4 Glioma . . . . . . . . . . . . . . . . 81

5.4 .5 Mama . . . . . . . . . . . . . . . . . 82

5.5 Genes Selecionados . . . . . . . . . . . . . . . . . . . . 84

5.6 Considerações finais . . . . . . . . . . . . . . 87

6 Conclusão e Trabalhos Futuros $\quad 89$

6.1 Contribuições . . . . . . . . . . . . . . . . . . . . . . . . 99 90

6.2 Trabalhos Futuros . . . . . . . . . . . . . . . . . . . . 90

Referências Bibliográficas $\quad 92$ 


\section{Lista de Figuras}

2.1 Excmplos de células genéricas. Imagens adaptadas de (Lodish et al., 1999) 8

2.2 Representação de molécula de DNA. Imagem extraída de (Filho, 2003). . . 9

2.3 Proceso de expressão gênica. Adaptado de (Casley, 1992). . . . . . . . . . . 13

2.4 Microarray de DNA complementar. Imagens adaptadas de (Harrington

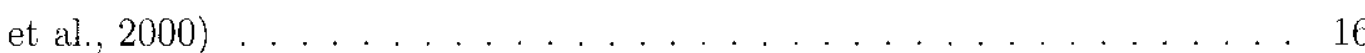

2.5 Microarray de DNA complementar. Imagens adaptadas de (Harrington

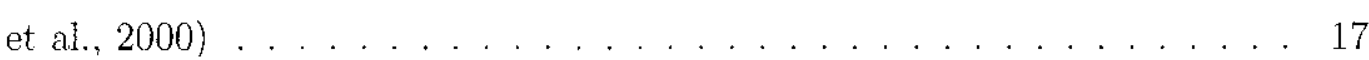

3.1 Ilustração da Minimização Estrutural de Risco. O valor ótimo para $\mathrm{k}\left(\mathrm{k}^{*}\right)$ ó determinado por um equilíbrio entre o termo de confidência e a quantidade de erros obtidos no conjunto de treinamento. . . . . . . . . . . . . 26

3.2 Conjunto linearmente separável, o hiperplano separador c a regra de decisão. 27

3.3 Vários hiperplanos são capazes de separar dados de classes linearmente separáveis. . . . . . . . . . . . . . . . . . 28

3.4 Hiperplanos canônicos e os vetores de suporte. . . . . . . . . . . . . . . . 29

3.5 Margem de separação. . . . . . . . . . . . . . . . . . . . . . . . 29

3.6 Conjunto de dados de classes não-linearmente separáveis. . . . . . . . . . . . 32

3.7 Variáveis de folga $\xi_{i} \ldots \ldots \ldots \ldots$. . . . . . . . . . . . . . . . . . . . . . . .

3.8 Conjunto de dados não-linear . . . . . . . . . . . . . . . . . . 34

3.9 Mapeamento Espaço de entrada - Espaço de saída. . . . . . . . . . . . . . 35

4.1 Seleção de características como um problema de busca. Blum e Langley (1997) 40

4.2 Seleção de características baseada em filtros. . . . . . . . . . . . . . . 44

4.3 Pseudo-código do ReliefF. . . . . . . . . . . . . . . . . . 51

4.4 Seleção de características baseada em wrappers. . . . . . . . . . . . . . 54

4.5 Fluxograma do um AG simples. Adaptado de (Deb c Kalyanmoy, 2001) . . 58 


\section{Lista de Tabelas}

1.1 Principais objetivos do PGH (Collins et al., 2003) . . . . . . . . . . . 2

2.1 Mapeamento entre códons e aminoácidos. Tabela extraída de (Lodish et al., 1999). . . . . . . . . . . . . . . . . . 12

3.1 Principais kernels . . . . . . . . . . . . . . . . 36

4.12 exemplos de uma base de dados representados por 4 características. . . . 52

5.1 Parâmetros utilizados pelas 2 versões do AG-Filtro . . . . . . . . . . . 69

5.2 Parâmetros utilizados pelo AG-SVM . . . . . . . . . . . 70

5.3 Descrição numérica das bases de dados . . . . . . . . . . . . . 73

5.4 Erro estimado (\%) utilizando diferentes números de genes. Base de leucemia. 75

5.5 Percentuais de erro de teste para cada técnica. Base de leucemia. . . . . 75

5.6 Comparação entre os métodos propostos. Base de leucemia . . . . . . . 76

5.7 Erro estimado (\%) utilizando diferentes números de genes. Basc de linfoma. 78

5.8 Percentuais de erro de teste para cada técnica. Base de linfoma. . . . . . 78

5.9 Comparação entre os métodos propostos. Base de linfoma. . . . . . . . . 79

5.10 Erro estimado (\%) utilizando diferentes números de genes. Base de cólon. . 80

5.11 Percentuais de erro de teste para cada técnica. Base de cólon. . . . . . . . 80

5.12 Comparação entre os métodos propostos. Base de cólon. . . . . . . . . 81

5.13 Erro cstimado (\%) utilizando difcrentes números de genes. Base de glioma. 82

5.14 Percentuais de erro de teste para cada técnica. Base de glioma. . . . . . 83

5.15 Comparação entre os métodos propostos. Base de glioma. . . . . . . . . 83

5.16 Erro estimado (\%) utilizando diferentes números de genes. Base de mama. 84

5.17 Percentuais de erro de teste para cada técnica. Base de mama. . . . . . . 85

5.18 Comparação entre os métodos propostos. Base de mama. . . . . . . . . 85 
5.19 Identificação e descrição dos genes selecionados. Base de leucemia. . . . . 86

5.20 Identificação e descrição dos genes selecionados. Base de linforna. . . . . 86

5.21 Identificação e descrição dos genes selecionados. Base de cólon. . . . . . . . 86

5.22 Identificação e descrição dos genes selecionados. Base de glioma. . . . . . 87

5.23 Identificação e descrição dos genes selecionados. Base de mama. . . . . . 87 
Capítulo 1

\section{Introdução}

\subsection{Contexto}

Os seres vivos podem ser considerados conjuntos de elementos organizados em uma sucessão de níveis de complexidade (Lodish et al., 1999). Por exemplo, os organismos contêm órgãos; os órgãos são compostos de tecidos; os tecidos são constituídos de células; e as células são formadas por diversos tipos de moléculas. Nesta cadeia, as células são tidas como as unidades biológicas mínimas, onde a maioria dos processos metabólicos acontece. A coordenação de todas as atividades do complexo aparato celular é realizada pelos genes.

Os genes são os fatores responsáveis pela hereditariedade, ou seja, por determinar as características de uma espécie através das gerações, assim como por codificar os traços específicos dos indivíduos (Casley, 1992). Eles também são responsáveis por codificar as informações essenciais para a manutenção da dinâmica celular. Para melhor compreender como eles realizam todas essas tarefas, é preciso conhecer sua composição. Quimicamente, os genes são sequîencias contíguas de ácido desoxirribonucléico (DNA) (Hunter, 1993). Cada molécula de DNA é formada por uma sequiencia de estruturas chamadas nucleotídeos.

Embora as moléculas de DNA sejam relativamente simples e bem compreendidas estruturalmente, até recentemente pouco se sabia acerca da seqüôncia completa de nucleotídcos dos genomas (um genoma é o conjunto de todos os genes de um organismo) em geral e cm especial do ser humano. Esta carência foi suprida com o desenvolvimento de diversos projetos de seqüenciamento genômico, dentre os quais o mais conhecido é o Projeto Genoma Humano $(\mathrm{PGH})^{1}$

Em abril de 2003, foi anunciada a conclusão do PGH (Collins et al., 2003). Os principais objetivos previamente estabelecidos foram cumpridos, conforme pode ser visto na.

${ }^{1}$ Embora apenas o PGH seja citado aqui, a empresa Celera Genomics também conseguiu sequenciar o genoma humano (Venter et aì., 2001). 
Tabela 1.1 e agora o foco das pesquisas passou a ter um caráter mais qualitativo, passando do simples armazenamento de dados biológicos para a análise dos mesmos.

\begin{tabular}{|c|c|c|c|}
\hline Área & Objetivo & Realizado & Data \\
\hline Mapeamento genético & $\begin{array}{l}\text { Mapa de resolução de } 2 \text { a } 5 \\
\text { Centimorgans }\end{array}$ & $\begin{array}{l}\text { Mapa de resolução de } 1 \\
\text { Centimorgans }\end{array}$ & $09 / 1994$ \\
\hline Mapeamento físico & $\begin{array}{l}30.000 \text { sequence-tagged si- } \\
\text { tes }\end{array}$ & $\begin{array}{l}52.000 \text { sequence-tagged si- } \\
\text { tes }\end{array}$ & $10 / 1998$ \\
\hline Sequiência de DNA & $\begin{array}{l}\text { Conclusão com } 99,99 \% \text { de } \\
\text { acurácia de } 95 \% \text { da sequĉn- } \\
\text { cia genômica que contém } \\
\text { genes }\end{array}$ & $\begin{array}{l}\text { Conclusâo com } 99,99 \% \text { de } \\
\text { acurácia de } 98 \% \text { da sequên- } \\
\text { cia genômica que contém } \\
\text { genes }\end{array}$ & $04 / 2003$ \\
\hline $\begin{array}{l}\text { Capracidade e custo da seqüên- } \\
\text { cia finalizada }\end{array}$ & $\begin{array}{l}500 \text { milhöes de bases/ano a } \\
<\$ 0,25 \text { a base }\end{array}$ & $\begin{array}{l}>1.400 \text { milhöes de ba- } \\
\text { ses/ano a }<\$ 0,09 \text { a base }\end{array}$ & $11 / 2002$ \\
\hline Variaçäo da seqüência humana & $\begin{array}{l}100.000 \text { single nucleotide } \\
\text { polymorphisms mapeados }\end{array}$ & $\begin{array}{l}3,7 \text { milhöes de single nucle- } \\
\text { otide polymorphisms ma- } \\
\text { peadios }\end{array}$ & $02 / 2003$ \\
\hline Identificação de genes & $\begin{array}{l}\text { DNA complementares hu- } \\
\text { manos completos }\end{array}$ & $\begin{array}{l}15.000 \text { DNAs complemen- } \\
\text { tares completos }\end{array}$ & $03 / 2003$ \\
\hline Organismos modelo & $\begin{array}{l}\text { Seqüencias de E. Coli, } S \text {. } \\
\text { cercvisiae, C. elegans. D. } \\
\text { melanoganster }\end{array}$ & $\begin{array}{l}\text { Sequiências de E. coli, S. ce- } \\
\text { revisiae, C. elegans,D. me- } \\
\text { lanoganster, e versöes pre- } \\
\text { liminares de outros orga- } \\
\text { nismos }\end{array}$ & $04 / 2003$ \\
\hline \multirow[t]{5}{*}{ Análise Funcional } & $\begin{array}{l}\text { Desenvolver tecnologias de } \\
\text { escala genômica }\end{array}$ & $\begin{array}{l}\text { Síntese de oligonucleotí- } \\
\text { deos em larga escala }\end{array}$ & 1994 \\
\hline & & Microartays de DNA & 1996 \\
\hline & & $\begin{array}{l}\text { Bibliotecas normalizadas e } \\
\text { corrigidas de DNA comple- } \\
\text { mentar }\end{array}$ & 1996 \\
\hline & & $\begin{array}{l}\text { Manipulação genética do } \\
\text { genoma inteiro de eucari- } \\
\text { ontes (levedura) }\end{array}$ & 1999 \\
\hline & & $\begin{array}{l}\text { Desenvolvimento em larga } \\
\text { escala de sistemas híbridos } \\
\text { para a interaçāo entre pro- } \\
\text { teínas }\end{array}$ & 2002 \\
\hline
\end{tabular}

Tabela 1.1: Principais objetivos do PGH (Collins et al., 2003)

No contexto da era pós-genômica, Collins et al. (2003) vislumbraram a influência do conhecimento obtido com o seqüenciamento dos genomas nas áreas sociais, da biologia e da saúdc c propuseram aos cientistas, para os próximos anos, alguns desafios. Para a área da saúde, os desafios são:

1. a identificação da contribuição genética à ocorrência de doenças e à resposta a medicamentos; 
2. a identificaçào de variantes de genes que contribuam para manutenção da sańde e para a resistência a doenças;

3. o desenvolvimento de abordagens para estimar a suscedibilidade a doengas a a modicamentos. a detecão precoce de doenças e a distinção molecular do estados patológicos

4. o desenvolvimento de novas terapias genéticas;

5. a investigação do cono integrar a informação relativa a riscos genéticos ao cotidiano clinico o;

6. o desenvolvimento de ferramentas que ajudem a melhorar os servicos de saúde

\subsection{Motivação}

Os dados gerados pelo PGH têm permitido aos cientistas identificar um grande número de genes a partir de seqüencias antes desconhccidas do DNA. Uma das maneiras mais ntilizadas de analisar esses novos genes é medir seus níveis de expressão. Com isso, porte-se estimar o quanto o gene influencia no funcionamento de uma célula em um dado momento e sob uma circunstância específica.

T'ara liklar conn a grande quantidado de genes descobertos, várias tecnologias têm sido descuvolvidas. As mais comuns são os microartays (Schena, 1999). que permitem nonitorar simultaneamente os níveis de expressão de milhares gones. Por meio da comparação das expressões gênicas de diferentes tipos de tecidos, condições clínicas ou organismos, os microarrays tom auxiliado a elucidar as funções dos genes e suas interaçòes, assim como ajudado no diagnóstico de docnças e na verificaçào de resposta a medicamentos (Sharan et al., 2002).

Os experinentos em larga escala envolvendo expressão genica representam un glande desafio computacional, à medida que mon onome conjunto de dados deve ser considerado (Hemolaeva et al., 1998). Entretanto, na maior parte clos casos o tipo de análise realizarda envolve extrair padröes clos dados e entender seus significados. I)esta forma, é pertinente falar-se da extração automática de conhecimento através de tócnicas de Aprendizado de Máquina como solução viável.

O Aprondizado de Máquina (AM) (Nichalski ot al., 1983) é um campo de pesquisa da. Inteligencia Artificial que estuda o desenvolvimento de métodos capazes de extrair 
conceitos (conhecimento) a partir de amostras de dados. Em experimentos envolvendo microarrays ć comum utilizar AM tanto no paradigma de aprendizado năo-supervisionado quanto no supervisionado. $\Lambda$ diferença básica entre os 2 paradigmas concerne à disponibilidade a prom da classe on categoria a que pertence cada amostra do dado. No primeiro caso, as classes são especificadas enquanto que no outro não. Detalles sobre ambas abordagens podem ser encontradas em (Theodoridis e Koutroumbas, 1999).

Eim dados de expressão gênica. o enfoque dos algoritmos de AM supervisionados normalmente está cm identificar novos subgrupos de entidades biológicas (Golub et al., 1999a) ou realizar agrupamento de genes com a finalidade de inferir suas funções (Fisen et al., 1998). Nos algoritmos supervisionados, a intenção é classificar genes on anostras de tecido em classes conhocidas (Brown et al., 2000) (Golub et al., 1999a).

Nesta disscrtação, será considerado o paradigma supervisionado para a classificaçõo de amostras de tecidos cancerosos com base em seus níveis de expressão gênica. O intcresse nosse tema foi suscitado por seu possível impacto no diagnóstico e tratamento do câncer e pela participação do autor deste trabalho no Projeto Genona Clínico do Câncer, financiado pela FAPESP.

En abordagens tradicionais, a classificação de tumores é baseada primariamente em sua aparencia morfológica (Golub et al., 1999a) e no tecido onde a doença se originou (Slonim et al.. 2000). Entretanto. nào há garantias de que tumores parecidos tenham o mesmo desenvolvimento clínico e, por conseguinte, exijam o mesmo tipo de tratamento. Assim. o estudo de técnicas que permitam determinar o tipo correto de cancer de uma amostra com uma maior taxa de acerto é essencial

Para prover um maior entendimento da amostra estudada e tentar promover uma classificação mais acurada de tumores, Golub et al. (1999a) 11tilizaram dados do nível de expressão gênica provenientes de microarrays. Em seus experimentos, o metabolismo do células pertencentes a dois tipos de tumores foi analisado e un padrão pôde ser aprendido. Com isso, foi possível classificar novas amostras doentes utilizando-se apenas seus níveis de expressão gentica.

A pós o trabalho pionciro de Golub, houve grande interesse na classificação de amostras de tecidos utilizando dados de expressão gênica (Mukherjee et al.. 1999) (Slonim ct al., $2000)$ (Ben-Dor ct al., 2000a) e vários algoritmos de A.M foram utilizados para cssa tarofa. Dentre os mais promissores. destacam-se as Máquinas de Vetores de Suporte. 
As Máquinas de Vetores de Suporte (SVMS, do ingles Support Vector Machines) (Cristianini e Shawe-Taylor: 2000a) são um método de aprendizado supervisionado baseado no trabalho de Vapnits e Chervonenkis (Vapnik o Chervonenkis, 1961). Elas aprendem delineando, a partir do oxomplos, uma fronteira ótima que separa elementos de duas classos distintas. Com isso, una regra de classificaça linear gerada om um espaço de alta dimensionalidade pode ser aplicada para determinar a classe de novos elementos. Fsta técnica tem sido utilizada com sucesso on diversas aplicaçoes do bioinformática² (Guyon et al., 2002) (Ding o Dubchak, 2001) (Joel ct al., 2001)

As grandes vantagens das SVMs são seu poder de generalização, ou seja, sua eficiência para classificar dados uão vistos durante a fase de aprondizado do algorituno, esua robustey para daclos de grande dimensão como os oriundes de experinentos de microarrays.

Entretanto, mesmo com essas vantagens. vários estudos sugerem que esses algoritmos podem se beneficiar de una redução na quantidade de característica a serem consideradas (Weston et al., 2000) (Zhang e Liu, 2002), principalmente no domínio de dados de expressão gênica, onde milhares do genes (características para as SVMs) estão disponíveis e possivelmente nem todos participam do procosso biológico estudado.

\subsection{Objetivos}

l'ara realizar a redução de dimensionalidade, será dada ênfase às técnicas de seleção do características (Theodoridis e Koutroumbas, 1999). A seleção de características pode? ser entendida como um processo que escolhe um subconjunto ótimo de características de acordo com unn certo critério. Alguns dos benefícios clesta prática podem ser listados (Tju e Motoda, 1998a) (Hall, 1999)

1. menor quantidade de dados requerida para o aprendizado;

2. menor processamento e consegüente dininuição no tempo de execução do algoritmo (1) $\Lambda \mathrm{M}$;

3. melhora do desempenho do classificador e;

4. a possibilidade de um molhor entendimento do conhecimento aprendido.

O presente trabalho tem como objetivo principal comparar diversas técnicas de seleção de características para SVMs aplicadas a beases rcais de expressão gênica proveniontos

${ }^{2}$ Bionformatica consiste, genericamente. na aplicaçăo de ferramentas computacionais para ajudar a resolvor os problemas dia Biologia Molecular. 
de experimentos de microarrays. Outro objetivo é propor novas técnicas bascadas an Algoritmos Genéticos (Goldberg. 1989) para selecionar subconjuntos de genes otinizados para o problema em estudo.

\subsection{Organização da dissertação}

O restante do trabalho será dividido conforme segue. No Capítulo 2, são introduzidas algumas tecnologias utilizadas para a análise de expressão gênica en larga escala. No Capítulo 3, as bascs teóricas das SVMs são apresentadas. No Capítulo 4, é considerado o problema da seleção de características, assim como sua aplicação em dados de expressão gênica e sula relevância paras as SVMs. As téculeas propostas também säo detallaadas noste capítule. No Capítulo 5, os experinentos conduzidos são descritos o os resultados são analisados. Por firn, no Capítulo 6, algumas consideraçóes finais são tecidas e melhoramentos e trabalhos futıros são sugeridos. 
Capítulo 2

\section{Análise de Expressão Gênica}

\subsection{Considerações Iniciais}

Recentemente, considerável esforço tem sido despendido para uma maior compreensäo dos seres vivos, do ponto de vista biológico. Uma prova disso são os diversos projetos de sequenciamento genômico, que visam a construção de mapas genômicos das espéciess cistudiadas.

Fstes empreendimentos têm gerado uma cnorme quantidade de dados. Por exemplo, o Projeto Genoma Humano estima que o ser humano possua cerca de 30.000 genes que codificam proteínas (Collins et al, 2003). Entretanto, o simples fato de estes dados já. serem conhecidos e disponíveis não é de grande valia enquanto eles não forem analisados.

Para auxiliar na realização das análises devidas, diversas tecnologias têm sido empregadas. Aquelas que permitem medir os níveis de expressão de milhares de genes simmltaneamente astão entro as mais utilizadas. Neste contexto, técnicas como macrourays (Schena, 1999), SAGF (Velculescu et al., 1995) o MPSS (Brenner et al., 2000a) tem ajudado os cientistas a compreender melhor como os sistemas biológicos funcionam, permitindo, com isso, avanços cm diversas áreas, como a medicina, a biologia e a agricultura, cutre outras (Casey, 2001).

Este capítulo visa fornccer ao leitor uma visão geral sobre essas novas ferramentas. Para tanto, inicialmente, alguns conceitos básicos de biologia molecular săo apresentados.

\subsection{Conceitos biológicos}

\subsubsection{Células}

Todos os seres vivos são formados por unidades básicas denominadas células (Okura, 2002). Elas correspondem a compostos estruturais e funcionais onde a maioria dos processos metabólicos acontece. 
Fisicamente, as células são constituídas de uma membrana externa, conhecida como membrana plasnáticicl, que define scus limites e mantém as diferenças essenciais entre os moios intemo e externo, c clo citoplasma, onde estão difusas as cliversas organclas chlulares. Hár também uma região nuclear, responsável por parte do material genético. Teste ponto, é commm fazer uma diferenciação entre organismos procariontes o encariontess (Lodish et al. 1999). Os primeiros não possuem uma membrana de separaçăo nítida ontre o citoplasma e a região nuclear e aprescutarn urna organização interna mais simples. Os segundos possuem uma estrutura interna mais complexa, inclusive com uma membrana bem definida envolvendo a região nuclear.

Como exemplos de organismos procariontes, pode-se citar as bactérias. Já plantas c animais são organismos encariontes. Para ilustrar a diferença cntre estes 2 tipos de organização colular, a. Figura 2.1 mostra micrografias eletrônicas de células genćricas do eucariontes e procariontes, com destaque para algumas estruturas colulares.

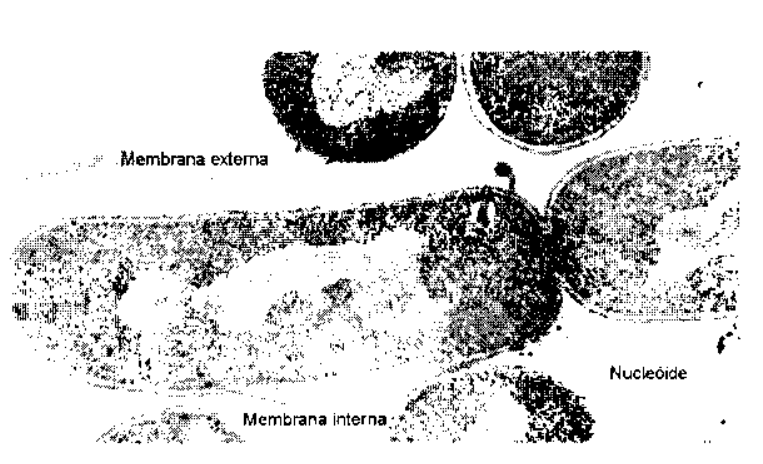

(a.) Procarionte

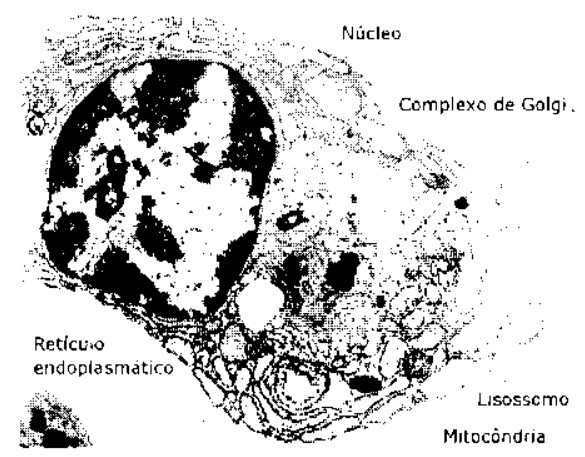

(b) Eucarionte

Figura 2.1: Exemplos de células genćricas. Imagens adaptadas de (Lodish ot a1., 1999)

Cada estrutura da célula é rosponsável pela execução de funções específicas (Lodish ot al., 1999) (Hunter, 1993). A seguir, tem-se algumas estruturas e a descrição do sluas funçỡes:

1. lisossomos: atuam na digestão de componentes celılares desgastados e de cortas substâncias extra-celulares;

2. mitocôndria: cuida da produção de energia a partir do consumo de oxigênio;

3. complexo de Golgi: tem como principal função a sccreção de substâncias:

1. retículo cndoplasmático: responsável pela síntese de glico-proteínas e lipídios:

5. ribossomos: realizam a sintese de proteínas:

6. núcleo e nucleóide: responsáveis por abrigar o material genético das cólulas. () 
núcleo é encontrado em seres eucariontes e o nuclcóide em seres procariontcs.

A coordenação e regulação de todas as atividades do aparato cclular ć de responsabilidade dos genes.

\subsubsection{Cromossomos, DNA e genes}

Os genes correspondem às unidades físicas o funcionais responsávcis pelos traços hereditários dos organismos vivos (Casley, 1992). Fles foram primeiramente investigados por Mendel no final do século 19 (eles foram reconhecidos, naquele trabalho, como fatorcs que passam, sem serem modificados, do progenitor para a progênie), em seus experimentos com cruzamento de ervilhas (Mendel, 1865). Vários décadas depois, descobriu-se os chamados cromossomos, que, observou-se, eram transmitidos de pai para filho. Este fato suscitou a idćia de que os cromossomos carregariam a informação genética (Silva, 2001). O interesse polos cromossomos resultou na posterior descoberta de que eles são compostos por moléculas de ácido desoxirribonucléico (DNA) o que os genes são, de fatto, segmentos contíguos de uma molécula de DNA ondo estâo armazenadas as informações genéticas (Hunter, 1993).

Una molécula de DNA consiste de duas cadeias complementares entrelaçadas cm uma estrutura que lombra uma dupla hélice (Casley, 1992). Cada cadeia é composta por una sequência de unidades químicas simples, chamadas de nucleotídeos. Esstes são formadus de fosfato, açúcar (do tipo desoxirribose) e una das quatro bases: Adenina (A), Guanina (G), Citosina (C) e Timina (T) (Shamir ct al. 2002a). A ligação entre os nucleotírleos do culeids complementares de DNA é realizada pela regra: a base $A$ se liga com a base $I$, e a base $\mathrm{C}$ com a base $\mathrm{G}$, conforme ilustrado na Figura 2.2 .

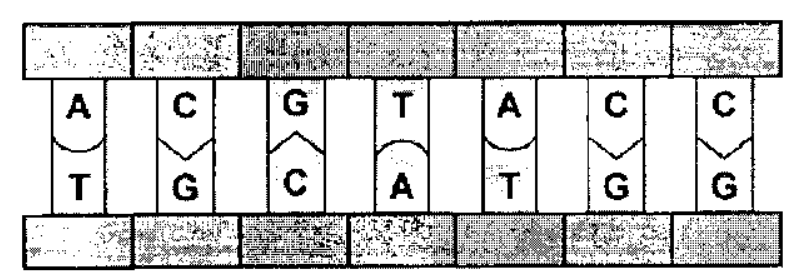

Figura 2.2: Representação de molécula de DNA. Imagem extraíla de (Filho, 2003). 


\subsubsection{Proteínas e expressão gênica}

A razao pela qual se diz que os genes controlan o metabolismo de uma célula está intimamente relacionada com o fato de eles codificarem protémas. Em outra palavras, os genes contêm as informações necessárias para que um maquinário celular consiga sintetizar proteínas (Lodish st al., 1999). Proteínas são os principais blocos cstruturais e funcionais da cólula, correspondendo a aproximadamente de 15 a $20 \%$ de seu peso total (Hunter, 1993). Elas sino formadas por unidades conhecidas como animoácidos, que se ligam linearmente. resultando em ma cadoia chamada de polipeptídeo. As funçoes das proteínas são diversas, dentre as quais pode-se destacar (Hunter, 1993) (Casley, 1992):

1. catalisadora de reaçoes bioquímicas, por meio das proteínas enzimáticas;

2. estrutural, como no caso do colágeno responsável pela conexão entre os ossos e os tecidos $\mathrm{s}$

3. de manutenção do anbiente celular. regulando a passagem de moléculas entre a. célula e o meio externo.

A fabricação de proteínas acontece cm, basicamente, duas etapas: a transcrição e a traduşão (Silva, 2001). Na prineira, una molécula de RNA (ácido ribonucléico) é sintetizada a partir de uma das cadeias de DNA (Okma, 2002)

O RNA é uma sequência de nucleotídeos similar ao DNA. As principais diferenças entre ambos são (Shamir et al., 2002b):

1. o RNA é uma nolécula de cadeia simples;

2. a base Timina ó substituída pela base Uracila;

3. o açúcar utilizas lo é do tipo ribose e;

4. as moléculas de RNA podem ser facilmente encontradas diluidas no citoplasman.

Há 3 tipos de moléculas de RNA (Silva, 2001):

1. o RNAm (monsageiro), que contém a scqüencia que codifica una proteńna;

2. O RNAt (transportador), que carrega os aminoácidos até os ribossomos e;

3. o RNAr (ribossômico), que faz parte dos ribossomos.

A transcrição ocorre por meio da ação de uma enzima chamada RNA polimeraso aplicada a locais específicos da seqüenciáa de DNA, conhecidos como promotores, que informam onde a transcrição terá início. O processo pode ser descrito, de forma geral, cono segue: inicialmente, a RNA polinerase reconhece o promotor na sequïencia de DNA e liga-se a ele através de certos fatores transcriciondis (Shamir et al. 2002b). Fm seguida, 
a RNA polimeraso desliza pela cadeia de DNA, sintetizando mma molécula de RNAm base a base, respeitando a complementaridade das bases (ver Figura 2.2 e o parágrafo anterior). (O processe tom fim quando a enzima encontra $14 m$ trecho do DNA conhecida como terminador (Silva, 2001)

$\Lambda$ transcrição ocorre de forma diferente em organismos encariontes e procuriontes. Nestes, a molécula de RNAm será diretamente utilizada para a produção de proteínas. enquanto que naqueles, ela sofre uma série de modificaçoes antes de ser traduzida (Okura, 2002). A principal modificação ocorre por meio do processo de splicing, pelo qual seqüiências não codificadoras de proteínas são removidas da molécula de RNAm (Silva, 2001).

Na outra etapa, a traduçào, a informação contida no RNAm recém-sintetizado é utilizada para dar origem a moléculas de proteína. Isto é feito da seguinte maneira (Shannir ot al., 2002a): 3 nucleotídeos adjacentes do RNAm são responsáveis por codificar um aminócido, que é parte constituinte das proteínas. Fsta tripla é chamada de códon. () códon que especifica o início da tradução é o (A, U e G). O mapeamento entre os códons e os aminoácidos codificados pode ser visto na Tabela 2.1. Em seguida, a molécula de RNAm se dirige ao ribossomo que juntamente com o RNAr, realiza a sintese de proteínas a partir dos códons. O processo termina quando os chamados códons de parada são encontrados. As regras pelas quais a seqüencia de nucleotífleos de $11 \mathrm{~m}$ gene forma a sequência do annunúridos das proteínas são conhecidas como Código Genético (Slamir et al., 2002a)

Ao processo pelo qual o Código Genético é convertido em estruturas operantes na célula dá-se o nome de expressão gênica (Casley, 1992). São considerados expressos os genes transcritos em RNAm e dopois traduzidos em proteínas e aqueles que são transcritos em outros tipos de RNA (como o RNAt) e que não săo traduzidos. O processo de expressăo gênica, cujo produto final são as protcínas, ć esquematizado na Figura 2.3

É importante ressaltar que durante o processo de expressão gênica, o nivel de RNAn le uma cólula en particular representa a atividade metabólica de un gene específico. Assim, pode-se entender melhor o papel dos genes de uma célula cm um dado momento (? sob uma determinada circumstância observando-se seus níveis de expressão.

Com base no que foi exposto, a comparação entre padrões de expresssões gênicas por meio da medição dos niveis de RNA mensageiro em células normais e doentes pode fornecer importantes indícios sobre o desenvolvimento de determinados estados patológicos, assim 


\begin{tabular}{lccccc}
\hline Posição 1 & \multicolumn{3}{c}{ Posição 2 } & \multicolumn{1}{r}{ Posição 3 } \\
\hline & U & C & A & G & \\
\cline { 2 - 5 } L & Phe & Ser & Tir & Cis & U \\
C & Phe & Scr & Tir & Cis & C \\
U & Leu & Ser & - & - & A \\
U & Leu & Scr & - & Tri & G \\
\hline C & Leu & Pro & His & Arg & U \\
C & Leu & Pro & His & Arg & C \\
C & Len & Pro & Glu & Arg & A \\
C & Lcu & Pro & Glu & Arg & G \\
\hline A & Iso & Tre & Asp & Ser & U \\
A & Iso & Tre & Asp & Ser & C \\
A & Iso & Tre & Lis & Arg & A \\
A & Met & Tre & Lis & Arg & G \\
\hline G & Val & Ala & Aca & Gli & U \\
G & Val & Ala & Aca & Gli & C \\
G & Val & Ala & Acg & Gli & A \\
G & Val & Ala & Acg & Gli & G \\
\hline
\end{tabular}

Tabela 2.1: Mapcamento entre códons e aminoácidos. 'labela extraida de (Lodish et al., 1999).

como informaçōes que podem levar a um melhor diagnóstico e tratamento mais eficaz.

Para que isso seja factívol, é desejável lidar com os genes implicados no doscrvolvimento do estado em questão. Contudo, na maioria dos casos, ainda não são conhecidos com exatidão quais genes estão envolvidos no processo. Assim, monitorar o maior número de genes possivel torna-se necessário. Neste sentido, as técnicas que conseguem lidar com grande quantidade de genes ao mesmo tempo surgem cono ferranentas promissoras para o cutendimento global de tais processos.

\subsection{Técnicas de Análise de Expressão Gênica}

Nesta Seção, algumas técnicas que permitem a análise conjunta de milhares de genes são abordadas. É dada enfase aos microarrays, devido a sua utilizaçầ ser mais comum e 

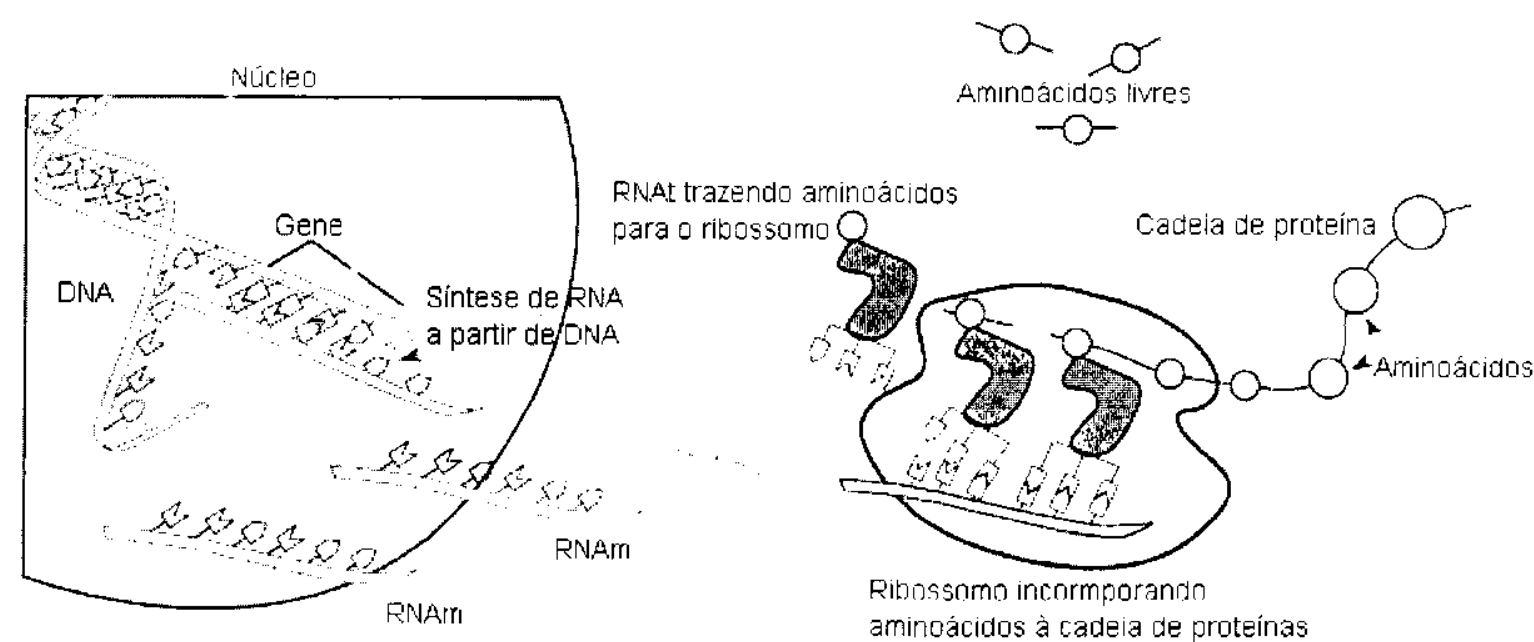

Citoplasma

Figura 2.3: Proceso de expressão gênica. Adaptado de (Casley, 1992).

haver, como consequiência, uma maior quantidade de trabalhos relacionados. Além disso. todos os experimentos conduzidos neste trabalho serão ffetuados com bases de dados de microarrays

\subsubsection{Microarrays}

Os microurays (Schend, 1999) (Lipshutz et al., 1999) são pequenas pastillas de alta densidade, fabricadas geralmente de vidro on de algum tipo do membrana fina, onde milhares de sequiências de DNA são dispostas em pontos fixos. A carda um destes pontos é associada um gene específico que, quando exposto a moléculas do teste de RN $N$ ou DNA fluorescentes, pode ser utilizada para deternimar quanto este gene está expresso no tecido en estudo. Com base nisto, ó possivel detectar, em um único experimento, a atividadr de um grande número do genes e analisar suas expressões e relações.

Entre as tecnologias de microarrays utilizadas atualmente, 2 tipos estäo mais difundidos: os microarrays de DNA complementar (Schena, 1999) e os microarrays de oligonucleotídeos (Lipshint\% ot al., 1999). A diferença básica entre eles ó que no princiro, a pastilha é preenchida com seciünncias de DNA sintetizadas previamente, compostas de algumas centenas de pares de bases, enquanto que no segundo, conjuntos de oligonucleotrideos sintetizados in situ são empregados. A seguir. descriçoes sucintas das 2 abordagens 
sio apresentadas ${ }^{1}$.

\section{Microarrays de DNA complementar}

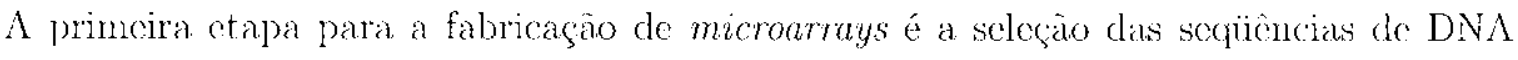
que serão dispostas na pastilha (Duggan et al., 1999) (Quackenbush, 2001). Elas devem ser bem caracterizadas e anotadas, para uma completa adequasão aos objetivos do experimento. Para organismos procariontes c alguns cucariontes simples, as seqü̈encias utilizadas são provenientes de DNA genômico ou de DNA complementar (DNAc) e para organismos eucariontes complexos, é comum utilizar fragmentos de EST's (do inglês Expressed Sequence Tags). ESTs são scqücncias curtas (poucas centenas de pares de basc) que servem como etiqueta para identificar um DNAc. (Woltsberg e Landsman, 2001). DNAc comesponcle a una cópia de DNA genônico feita a partir de RNAm. por meio de $1 m$ processo conhecido como transcrição reversá (Lodish et al., 1999).

Em seguida, as seqü̂ncias solecionadas de DNA são amplificadas por PCR (do inglês Polymerase Chain Reaction). PCR é uma técnica pela qual uma grande quantidade de DNA idêntico pode ser sintetizada a partir de uma molécula molde (Lodish et al., 1999). O produto deste processo é, então, parcialmente purificado, tipicamente por precipitação c filtragen por gel, e pode ser fixado na pastilha. A fixação é feita com o auxílio de clispositivos robotizados, que aplicam o produto de PCR cle cada gene a um ponto específico na pastilha, que depois sofre tratamentos químico e térmico para fixar as sequiências do DNA (Lodish et al., 1999). O processo de fabricação de un microarray é ilustrado na Figura $2.4^{2}$

Com as moléculas de DNA dispostas de maneira conhecida o ordenada sobre um microarray, diversos tipos de experimentos podem ser realizados. Uma das aplicaçón mais comuns permite comparar os níveis de expressões relativos de carla gene cm 2 amostras distintas, por exemplo. un tecido em seu estado saudável (normal) e docnte.

O processo é como segue, de maneira simplificada: inicialmonte, as 2 anostras de 10 cidos são coletadas e tên seu RNAm extraído e isolado. En seguida. moléculas de DNAc: são sintetizadas a partir do RNAm. Para distinguir moléculas de amostras diferentes. tintas fuorecentes são incorporadas aos mucleotídeos das seqü̈ências de DNAc durante a

\footnotetext{
${ }^{1} \Lambda$ s descriçôns que seguem sĩo genéricas e têm caráter meramente didáticu. Pura aplicaçöes reais. recomenda-se verificar as referencias fornecidas e procurar suporte profissional.

${ }^{2}$ Nà versăo eletrònica disponibilizada em www. saber.usp.br: a Figurà está coloriła
} 
transcrição reversa. Os pigmentos $C y^{3}$ (verde) e $C y \tilde{J}$ (vermelho) são commente utilizados na coloração.

Na próxima ctapa do experimento, os DNAc das amostras são cspalhados homogencamente por sobre a pastilha, permitindo cuc cles se acoplem às sequiencias do DNA fixas nos diversos pontos do microarray. Isto é possível devido ao processo de hibridização. scgundo o qual fitas de DNA (ou RNA) podem ligar-se quimicamente a fitas complementares (de acordo com as regras mostradas na Figura 2.2). O gran com que as moléculas de DNAc de cada amostra se hibridizam com o DN $\Lambda$ de 11 ponto reflete o nível relativo daquele determinado gene nas 2 condições em estudo.

Após a hibridizaçào, o microarray é lavado para a remoção de sequiências näo hibridizadas. $\Lambda$ seguir, do é lido por dispositivos eletrônicos (os scanners) que iluminam os pontos da pastilha e medem a fluorescencia de cada pigmento isoladamente, originando 2 imagens separadas. Por fim, as imagens são combinadas por snftware o a imagem resultante é analisada para determinar a intensidade relativa de fluorescência de cada gene. Este processo é ilustrado na Figura 2.4(a). Nela, é possível ver 3 genes hipotéticos, representados pelos pontos X, Y o Z. No primeiro, o ponto na pastilha é predominantemente vermelho, indicando que ó ele mais expresso em uma das amostra. O ponto verde indica que aquele gene ́́ mais cxpresso na outra amostra. O ponto anarelo indica un gene que ten nível de expressão similar nas 2 amostras.

Parra que us dados gerados pelos microarrays possam ser analisados na prática, ó necessário que os nívcis de expressão gênica estejam expressos cm forma numérica. Para isso. técnicas de processamento de imagens são empregadas. Segundo Yang ct al. (2000), inicialmente, o local de cada ponto na imagem do microarray deve ser delimitado. Depois, por meio de técnicas de segmentação, os pixels da imagem deven ser classificados como scrido dos pontos ou do fundo da imagem. Finalmente, a intensidade de cada ponto deve ser calculada.

Após o processamento das imagens, certos procedimentos de normalização devem ser aplicados para ajustar as diferenças entre os pigmentos e a capacidade de leitura do scanner para cada espectro de cor (Quackenbush, 2001). Algun tipo de normalização também é necessário para corrigir as diferenças de quantidades iniciais do RNAm utilizado em cada uma das amostras.

A expressäo final e de cada gene é dada pclo logaritmo da razão entre a intensidade 


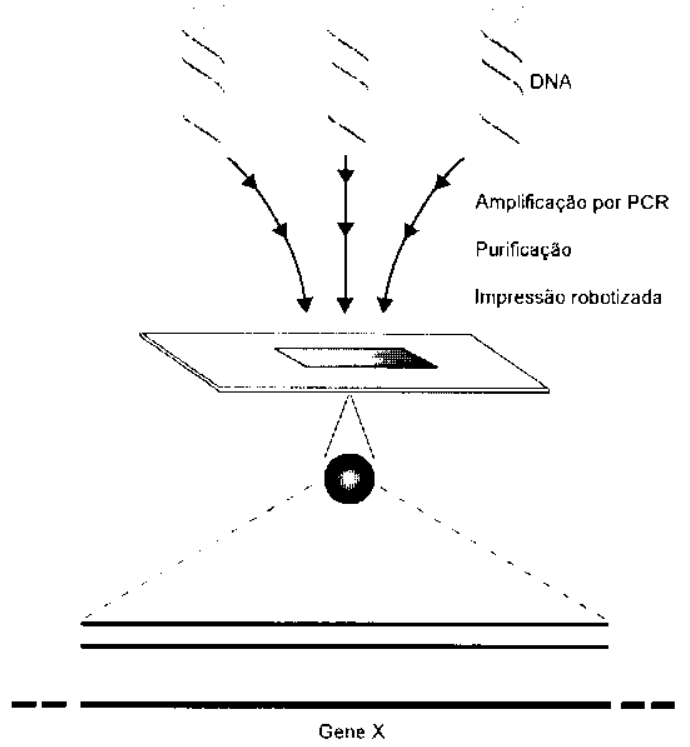

(a) Fabricaçäo

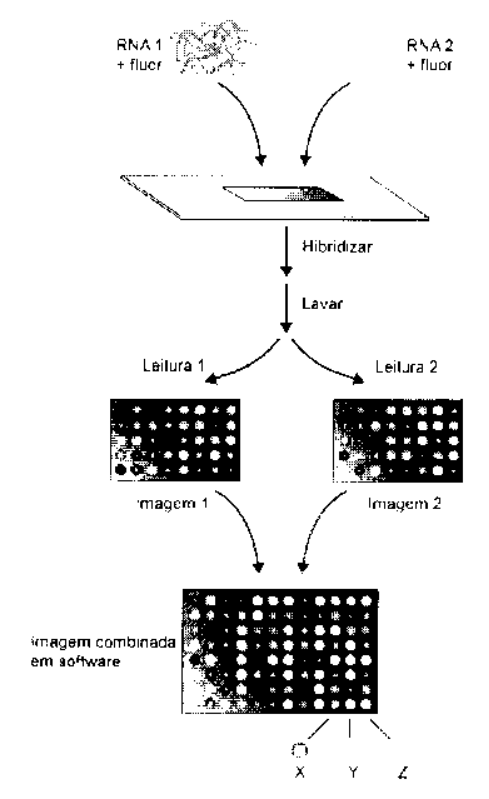

(b) Experimento

Figura 2.4: Microarray de DNA complementar. Imagens adaptadas de (Harrington ct al., $2000)$

obtida em uma amostra (DNAc tingido com o pigmento Cy5) e a intensidade obtida na outra amostra (DNAc tingido com o pigmento Cy.3), como mostra a Eq. 2.1:

$$
c=\log _{2}(C y 5 / C y 3)
$$

Este tipo de representação oferece algumas vantagens. A primeira é que ela cufatiza o fato de que microarrays de DNA complementar não fornecem dados de níveis de expressia alsolutos e sim muldanças no nível de expressão relativo em 2 condiçoes, o que poule ser mais interessante biologicamente (Eisen et al., 1998). A segunda é que o uso de logaritmo facilita o entendimento do fenômeno em estudo (Quackenbush, 2001). Por exemplo, sc um gene apresenta nível de expressão de 1, segundo a Eq. 2.1, então cle é expresso 2 veres mais om uma amostra quo om outra. So a cxpressão for -1, então ele é 2 vezes mais expresso na outra amostra. A principal desvantagen dessa representação é a perda ólsvia de informação quanto à intensidade absoluta dos níveis de expressäo.

\section{Microarrays oligonucleotídeos}

No lugar das seqüencias de DNAc utilizadas na abordagem anterior, pequenas seqü̈ncias de nucleotídeos (geralmente de 25 pares de bases), denominadass oligomucleotídeos, são 
fixadas no microarray. Elas são projetadas artificialmente via soflware para representar os genes selecionados para o experimento (Gibson e Muse, 2004) e sintctizadas in situ em uma pastilha de vidro. O processo de sintese destas seqüencias é baseado en técnicas de manufatura de circuitos integrados (Lodish et al., 1999)(Lipshutz et al., 1999).

Tipicamente, cada ponto do microarray contém milhares de conjuntos de 20 diferentes pares de oligonucleotídeos, que são utilizados para representar um gene (Choi, 2004). Os pares são compostos de 2 seqüências conhecidas como perfect match (PM) e mismatch (MM). Elas são idênticas, exceto por urna única diferença de base na posição central. mais especificanente. no décimo terceiro nucleotídeo, o que faz com que a sequênncia PM hibridize com uma seqüência de teste e a MM não. A utilização da seqüência MM visa controlar os efcitos do problema de hibridização cruzada, pelo qual pequenas sequências de outros genes hibridizam indevidamente con a seqüencia PM, diminuindo a especificidade da hibridização (Lipshutz et al., 1999). Alghuns autores discordam da utilidade da sequiência MM (Gibson e Muse, 2004)(Hucka e Szallasi, 2003). O processo de fabricaçüo dos microarrays de oligonucleotídeos é esquematizado na figura $2.5(\text { a })^{3}$.

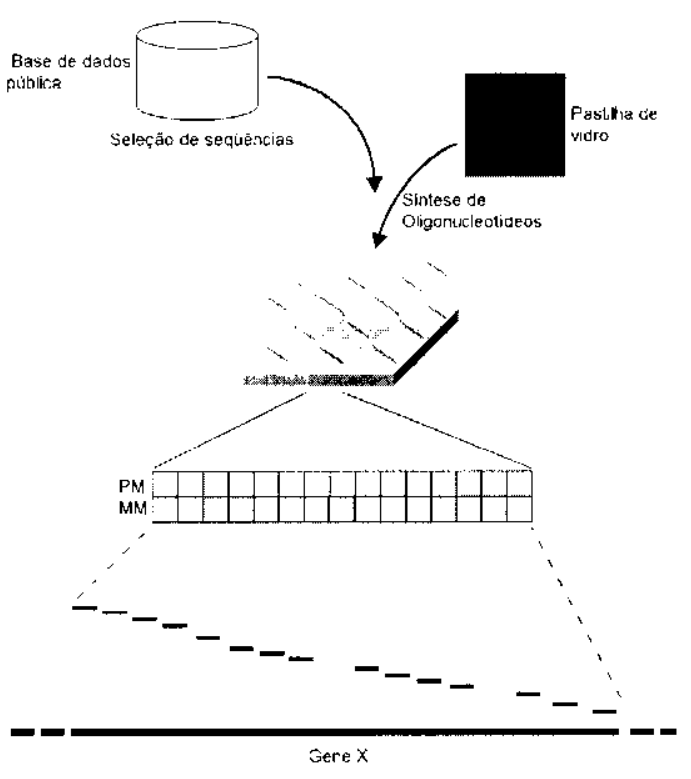

(a) Fabricaçäo

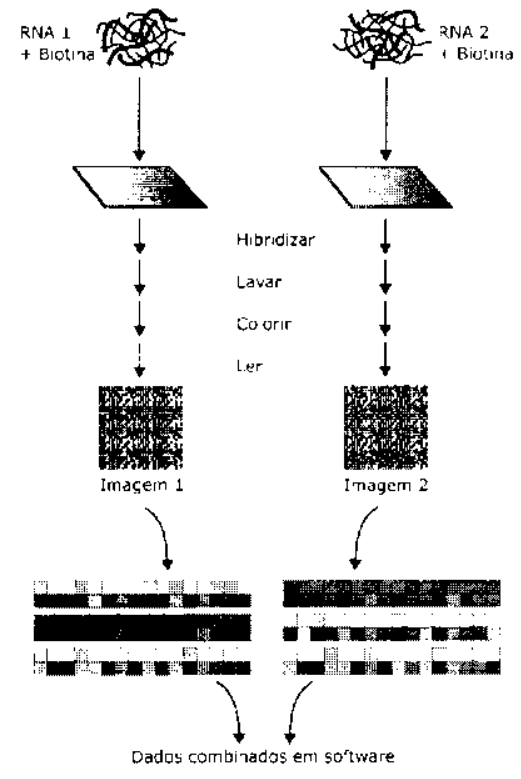

(b) Experimento

Figura 2.5: Microarray de DNA complementar. Imagens adaptadas de (Harrington et al., 2000)

Para analisar os niveis de expressäo dos genes om 2 amostras, inicialnnente faz-so a

\footnotetext{
${ }^{3} \mathrm{Na}$ versão eletronnica disponibilizada en www saber usp.br, a. Figura cstá colorida.
} 
coleta de RNA. Fm seguida, o RNA é submetido a um processo de amplificaçào linear em 2 fasses e mucleotideos marcados com biotina são incorporados às cópias de RNA durante a reação (IJarington et al., 2000)(Choi, 2004). O RNA é cntão espalhado por sobre a pastilha e as sequiencias hibridizam com os oligonucleotídeos ali depositados

As seqüencias de RNA que não hibridizaram são rcmovidas através de processos do lavagem e às restantes é adicionado o composto fluorescente Slreptavidin-Phycocrythrin. que se liga aos nucleotídens marcados con biotina (Gibson e Muse, 2004)(Choi, 2004). A Phycoerythrin pode ser detectada com o aluxílio de um scanner apropriado, possibilitando medir quanto RNA hibridizou com os oligonucleotídeos da pastilha. O nível de expressào de carla gene é calcularlo tendo como base a diferenģa média entre as sequiencias PM e MM referente àuele gene.

Na. Figura 2.5(b), que mostra os passos básicos do experimento, tem-se ilustrado conjuntos do oligonucleotídeos PM-MM para 3 genes hipotéticos. O gene X está mais expresso na amostra 2 que na 1 . O gene Y está mais expresso na amostra 2 que na 1 . O gene $Z$ está expresso em níveis similares nas 2 amostras.

\subsubsection{Serial Analysis of Gene Expression - SAGE}

Lma das principais desvantagens dos microarrays é sua limitação em trabalhar apenas com genes que já foram previamente identificados ( $\mathrm{Ng}$ et al., 2002). Isto se torna um problema uma vez que mitos genes que determinam certos estados celulares, como algumas patologias, não foram ainda descobertos (Venter et al., 2001).

Este problema não ocorre na técnica denominada Serial Analysis of Gene fxpression (SAGE) (Velculescu et al., 1995). Com ela, todo o RNAm contido on uma célula on tecido pode sar estudado, independente de os genes da amostra já terem sido identificados on não. A idéia básica do SAGE é assim resumida: as noléculas de RNAm coletadas podem ser, teoricamente, unicamente caracterizadas por um pequeno conjunto nuclcotídeos, geralmente dez, con cada nucluotídeo podendo ter como base associada $A, T, C$ ou G. Este conjunto é chamado de tag. Enu seguida, as tags säo concatonadas, formando uma serie de tags de todas as moléculas de RNAn da anostra. Posteriormente, essa série é clonada e scqüenciada. A quanticlade de tags é contada e assim obtém-se a frequêneia de cada molécula de RAAm. e consequentemente, o nível de cxpressão de cada gene.

Dentre as desvantagers do SAGE pode-se destacar que é uma técnica custosa, se 
comparada com os experimentos baseados em microarrays, por exemplo (Ng et al., 2002). Outro fator negativo do SAGE é que algumas tags podem não ser de fato únicas para cadar RNAm e também podem ocorrer problemas na nos processos de clonagom e de seqüienciamento, o que compromete a precisão do método (Stollberg ct al., 2000).

Lm dos primeiros trabalhos com SAGE foi na deteminação do perfil de expressão gênica de células normais e com câncor (Zhang et al., 1997). Mais recentemente cle foi utilizado en vários cstudos envolvendo câncer (Waghray et al., 2001) (Argani et al., 2001) (Caldwell et al., 2002) o cm pesquisas com plantas (Fujii e Amrein. 2002), cntre outros.

\subsubsection{Massive Parallel Signature Sequencing - MPSS}

Outra técnica que pemite a análise em larga escala de expressão gênica é a Massive Parallcl Signature Sequencing (MPSS) (Brenner et al., 2000a). Seu princípio de funcionamento ó scmelhante ao do SAGE. 'lodas as moléculas de RNAm são extraídas do tecido, e por neio de clonagem eseqüencianento, uma assinatura única é obtida para cada nolócula de RNAm. O número total de ocorrências de uma assinatura específica determina o nível de cxpressão de $u$ m detominado gene

A diferença básica entre o SAGE e o MPSS está na forma como ocorre a clonagem e o seqüenciamento. No MPSS, a clonagem é realizada por meio de uma tecnologia que forneco un conjunto de milhões de microbeads (pequenas esferas) (Bremer et al., 2000b), cada uma representando uma molécula de RNAm da amostra a ser estudada, e cada microbead contendo aproximadamente 100.000 fragmentos de DNAc identicos àquele RNAm.

O seqüenciannento ocorre com a aplicaçäo do MPSS propriamente dito: os microbeads produzidos na clonagem são fixados em uma placa de vidro e depois são expostos a uma sćric de roagentes químicos. Estes reagentes fazem com que, para cada microbead, seja gerada, em paralelo, uma assinatura que identifica o RNAm correspondente àquele microbead. Esta assinatura possui, geralmente, un tamanho de 17 a 20 nucleotídeos, é produzida a partir das milhares de moléculas de DNAc ligadas a cada esfera. Por fim, um software é responsável por contar a quantidade de cada assinatura e, assim, determinar o a expressão genica total da amostra.

A principal vantagem desta técnica com relação aos microarrays é que o MPSS não necessita que os genes tenham sido identificados previamente para conseguir medir seus níveis de expressão. Isto também é conseguido com a utilização do SAGE. Fntretanto, 
MPSS é mais sensível que o SAGE para analisar genes com níveis muito baixos de expressão (Constans, 2002). Além disso, o MPSS, em comparagão com o SAGE, oferece. menor possibilidade de ambigiiidade. pois utiliza nna assinatura maior para identifical cadia molécula de RNAm da amostra estudada. A grande desvantagem do MPSS é seu elevado custo, que o impossibilita de ser comumente utilizado.

Das técnicas citadas nesta Seção, o microarray é a mais adequada quando se descja analisar um número grande, porém mais limitado, de genes cm várias amostras, por possibilitar experimentos mais simples, mais rápidos e que envolvem monos custos. Por esta razão, as bases de dados disponíveis são mais mumerosas para csta tecnologia que para outras

Todas essas facilidades fizeram com que os dados de microarrays tenham se tomado populares en cstudos envolvendo $A M$, especialmente no paradigma supervisionado. Por isso, o presente trabalho abordará a análise de expressão gênica envolvendo dados obtidos de microarrays, É importanto ressaltar, no entanto, que está decisão é devida apenas a motivos práticos c que os cstudos realizados neste trabalho podem ser aplicados em dados oriundos das outras tecnologias.

\subsection{Considerações finais}

Neste Capítulo, foram revistas algumas tecnologias que propiciam a análise maciça de níveis de expressão gênica: com ênfase nos microarrays. Com base neste dados, diversos experimentos podem ser realizados. Algumas aplicações da utilização de AM em dados de expressão gênica são dostacadas:

- Função de genes: devido à grande quantidade genes existentes, conseguir descobrir a função de cada un é uma tarefa árdua. Entretanto, sabe-se que genes com cxpressöcs semelhantes têm grande probabilidade de apresentaron funçõos parecidas (Spellnan ot al., 1998) (Lisen et al., 1998). Sob essa premissa, técnicas de clusterizaçäo tên sido aplicadas para determinar a função de genes desconhecidos com baso om sua similaridade com aqueles já conhecidos. Alguns trabalhos cnvolvem agrupimento hicrárquico (Perou et al., 2000) e mapas auto-organizáveis (Tamayo et al., 1999).

- Redes genéticas: em sistemas biológicos reais, os genes não atuam de forma isolada. Genes podem regular o comportamento de outros genes. Assim, entender suas 
interações e poder inferir relações causais ó importante. Friedman et al. (2000) utilizaram redes Bayesianas para tal tarefa.

- Classificação: a classificaçào de genes isolados ou de amostras de tecido é essencial para um maior entendimento dos genes e para o tratamento adequado a determinadas doenças. Brown et al utilizaram SVMs para classificar genes isolados (Brown et al., 2000). Hwang ef al. (2002) fizeram uma análise conparando redes Bayesiandis. árvores neurais e redes neurais RBF na classificação de tecidos cancerosos. Dubitzky et al. (2001) realizaram a mesma classificação, mas com a utilização de redes neurais e árvores de decisão. SVMs têm sido utilizadas con sucesso na classificação de câncer em diversos trabalhos (Mukherjec et al., 1999) (Golub et al., 1999b) (Cai ct al., 2000).

Neste trabalho, vai-se Irabalhar com a classificação de amostras de tecidos utilizando SVMs, que serão ipresentadas no Capítulo 3. 
Capítulo 3

\section{Máquinas de Vetores de Suporte}

\subsection{Considerações Iniciais}

Recentemente, uma nova família de algoritmos de aprenclizado ten recebido muita atençán da comunidarle de AM. São as Máquinas de Vetores de Suporte, ou, simplesmente, SVMs (do inglès Support Vector Machines)(Cristianini o Shawe-Taylor, 2000b).

Elas têm obtido desempenho comparável, ou mesmo superior, a métodos clássicos em diversos dominios. Dentre as aplicaçöes mais comuns ${ }^{1}$, pode-se destacar seu uso em: domínios médicos (Takeuchi e Collier. 2004), análise de textos (Joachims, 2002), problemas de visão computacional (Zheng ot al., 2004) o bioinformática (Noble, 2004).

Para entender a razão de tal exito, é necessário examinar os princípios que servem de base a esta abordagem. Inicialmente, deve-se considerar que, do ponto de vista térico, as SVMs apresentam o respaldo da. Teoria do Aprendizado Estatístico (TAE) (Vapnik, 1995). Com isso, há garantias de que o nível de generalização em problemas de classificaçào seja maximizado.

Sob o aspecto prático, as SVMs apresentam soluções com boa cficiência computacional, permitindo assim seu uso em problemas de larga escala. Isto é possível devido à adoção de diversos conceitos interessantes, como programação quadrática convexa, representação dual e kernels.

Neste Capítulo, os fundamentos das SVMs serão sucintamente apresentados. A enfase será dada a problemas de reconhecimento de padroes binário. devido a sua importância para o presente projeto.

A organização do capítulo é como segue. Na Seção 3.2, a apresentada a Tooria do Aprendizado Estatístico. Na Seção 3.3, os diversos tipos de SVMs são abordados, no decorrer de 3 subseções. Para concluir, na Seção 3.4, algumas considerações finais são tecidas.

${ }^{1}$ Uma lista mais extensa das aplicaçöes de SVM pode ser consultada em www.support-vector.not e www.kernel-machines org. 


\subsection{Teoria do Aprendizado Estatístico}

Uima das grandes questões encontradas em AM diz respeito à capacidade de generalizaçäo do um classificador. O problema resume-se em: dado un classificador gerado por num algoritmo de aprendizado como determinar quão bom é seu desempenho em estimar saidas para entradas năo vistas durante a fase de treinamonto? Para lidar com esta dificuldade. nos idos da década de 60. Vapnik c Chemovenkis desenvolveram estudos que levaram à criação da Tooria do Aprendizado Estatístico (Vapnik, 1995), que formaliza a relação entre a capacidade de generalização do classificador, a complexidade da classe de funções que o algoritmo de aprendizado pode gerar e a minimizaçào dos erros no treinamento. A seguir, os pontos básicos da TAE serão abordados de mancira mais formal.

Considere um conjunto $S$ formado por $N$ elementos tal que $S=\left\{\left(\overrightarrow{x_{1}}, y_{1}\right), \ldots,\left(\overrightarrow{x_{N}}, y_{N}\right)\right\}$, onde $\overrightarrow{x_{i}} \in R^{M}$ e $y_{i} \in\{+1, \cdots 1\}$. Os vetores $\overrightarrow{x_{i}}$ possuem dimensão $M$ e são utilizados para representar objetos do mundo real, como, por exemplo, amostras de tecidos de pacientes. Os $y_{i}$ são conhecidos como rótulos o correspondem à classes de saida possíveis as quais os $\overrightarrow{x_{i}}$ podem estar associados. ()s pares $\left(\overrightarrow{x_{i}}, y_{i}\right)$ são os exemplos lotulados do conjunto do treinamento $\mathrm{S}^{2}$.

A tarefa de classificação binária (ou reconhecinento de padrões binário) consiste em descobrir un mapomento $\overrightarrow{x_{i}} \mapsto y_{i}$ através das caracteristicas dos elementos do conjunto S. A função que realiza esse mapcamento ć chamada de classificador e é definida como $f: R^{M} \mapsto\{+1,-1\}$, com $f \in F$, onde $F$ contém todos os possíveis classificadores que $1 \mathrm{~m}$ algoritmo de aprendizado pode induzir. A geração de um classificador por um algoritmo de aprendizado aplicado a um conjunto de exemplos rotulados ć realizada cm uma ctapa denominada treinamento.

Una vez escolhida uma função de mapcamento $f$, pode-se classificar elementos não vistos durante a fase de treinamento, através do computo de $\int\left(\overrightarrow{x_{i}}\right)$, para un $\overrightarrow{x_{i}}$ qualquer. Fste mapeamento só ć possível sob a condição de que os elementos desconhecidos ao classificador (coletivamente referidos como conjunto de teste) sejam gerados independentemente pela mesma distribuição de probabilidade $P$ (que gerou os elementos do conjunto 5 .

Dada a cardinalidade de $F$. escolher um classificador não é trivial, pois pode haver

${ }^{2}$ considerando-se aqui o paradigma de aprendizado supervisionado 
un grande número de mapeamentos entrada-saida disponiveis. Entretanto, para um dado conjunto de treinamento, é sempre desejável que o algoritmo de AM aprenda a melhor funça possível, on seja. aquela que cometa menos erros quando da classificara do um $\overrightarrow{x_{i}}$ do conjunto de teste. Define-se, então, a probabilidade Risco Esperado $R(f)$ para mensurar a capacidade de generalização de $\int$ (quanto menor o valor de $R(f)$, molhor o dassificador generaliza). Matematicamente, tom-so (Lin, 2000):

$$
R(f)=\int \frac{1}{2}|f(\vec{r})-y| d P(\vec{x}, y)
$$

Assim, para a construção de um bom classificador, cleve-se minimizar a medida $R(f)$. Contudo, ela depende de um termo que geralmente não tem valor conhecido, a probabilidade $P^{-}\left(x^{3}, y\right)$. As úmicas informação disponíveis são o conjunto de treinamento e a fannilia de funçoes $F$. Desta maneira, é necessária outra abordanem para garantir um valor pequeno de $R(f)$ sem que seja preciso a minimização explícita da Fequaçào 3.1.

Uma idéja imediata é simplesmente escolher a função f que minimize o crro durante a fase de treinamento esperando com isso que a quantidade de erros na classificação de dados novos também seja mínima. A poreentagem de classificaçoes incorrotas ubtidas para S dá-sc: o nome de Risco Empírico $R_{e m p}(f)$, cuja definição é:

$$
R_{c m p}(f)=\frac{1}{N} \sum_{i=1}^{N} \frac{1}{2}\left|f\left(\overrightarrow{x_{i}}\right)-y_{i}\right|
$$

onde $\left|f\left(\overrightarrow{x_{i}}\right)-y_{i}\right|$ representa o termo de perda quando se prediz a sajda desejacla $y_{i}$ a partir da saíla computada $f\left(\overrightarrow{x_{i}}\right)$.

Mas essa solnção, denominada de Minimização do Risco Empírico, nem sempre é ótima, podendo um classifieador que trabalha muito bem sobre os dados de $S$ (valor de $R_{\text {emp }}(f)$ pequeno) ter desempenho insatisfatório sobre o conjunto de teste (valor de $R(f)$ grande), caracterizando desta forma o overfitting (Vapnik, 1995).

Embora não seja possível calcular $R(f)$ e $u$ m valor pequeno de $R_{e m p}(f)$ năo implicar necessariamente em boa gencralização, uma relação muito importaute entre estas cluas mediclas é capaz de orientar a escolha de um classificador eficiente. A TAE dofine a Inequaça 3.3, verdadeira com probabilidade cle pelo menos $1-\eta$, para $N>h$ a para o termo de prerda de $R_{r m o}(f)$ assumindo valores () ou 1. como na Equacáo 3.2 (Vapnik, 1995):

$$
R(f) \leq R_{c m p}(f)+\sqrt{\frac{h(\log (2 l / h)+1)-\log (\eta / 4)}{l}}
$$


onde hepresenta a dimensão VC do conjunto $F, \eta$ é un valor real entro 0 e 1 o $N$ é a quantidade de exemplos do conjunto $S$. O temo da raiz quadrada é conhecido como termo de confictoncia.

$\Lambda$ dimensão VC (de Vapnik-Chervonenkis) é mma medida da capacidade ou poder de expressão da família de funções $F$ para lidar com a tarefa de classificação. Quanto maior seu valor, mais rico o conjunto $F$ e portanto, regras de classificação mais complexas podem ser aprendidas. Formalmente, a dimensão VC pode ser definida como o número máximo de exemplos de treinamento que podem ser separados pelas funções pertencentes a $F$. para todas as combinações de classes possíveis (Burges, 1998). Exemplos ilustrativos da determinação de $h$ para alguns conjuntos $F$ simples podem ser encontradas em (Haykin $1998\}$

A Inequacio 3.3 fornece um limite superior para um o Risco Esperado. Com isso, possível limitar o valor de $R(F)$, por meio da escolla adequada, por parte do algoritmo de aprendizado, de uma função $f \in F$ que mininize o Risco Empírico $h_{e m p}(f)$ c por mcio da determinação de uma classe de funçóes que mantenha o parânetro h pesqueno. P'ara esta última tarefa, divide-se o conjunto $F$ em uma hierarquia de subconjuntos da seguinte forma (Vapnik, 1995):

$$
\begin{gathered}
F_{0} \subset F_{1} \subset F_{2} \subset \ldots \subset F_{n} \subset F \\
\text { em que } V C\left(F_{0}^{\prime}\right) \leq V C\left(F_{1}\right) \leq V C\left(F_{2}\right) \leq \ldots \leq V C\left(F_{n}\right) \leq V C(F)
\end{gathered}
$$

Para selecionar a classe de funçōes é preciso observar alguns pontos:

- uma classe muito pecuena, como $F_{0}$, pode reduzir o termo da raiz quadrada na Incquação 3.3, enquanto o número de erros durante a fase de treinamento pode permanecer alto, dada a pouca expressividade da classe.

- uma classe muito grande, como $F_{n}$, pode reduzir o número de crros durante a fase de treinamento, encuanto o valor de $V C\left(F_{k}\right)$ leva a um grande termo da raiz quadrada na Incquą̧ão 3.3

Por meio destas observaçoes, conclui-se que deve haver uma classe intermediária que limita de maneira ótima o Risco Esperado $R(f)$, aliando um baixo Risco Empírico e uma pequena classe de funções. Ao processo de busca pela classe ótima dá-se o nome de Mininizaçào de Risco Estrutural (MRE). Fle ó ilustrado na Figura 3.1. 


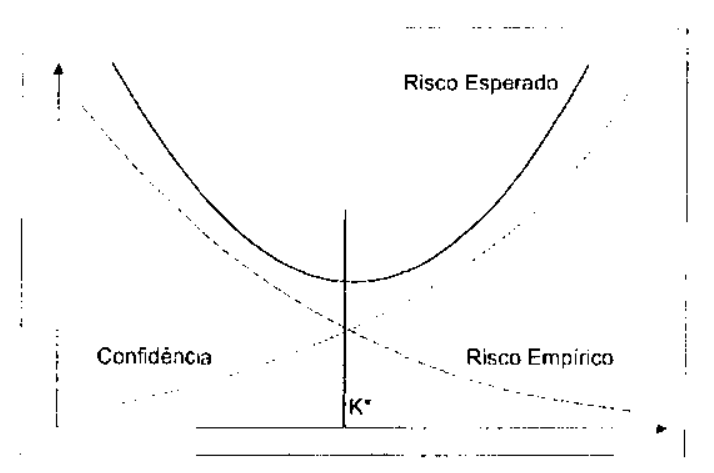

Figura 3.1: llustração da Minimização Estrutural de Risco. O valor ótimo para $k$ (k*é determinado por un conilíbrio entre o termo de confidencia e a quantidado de crros obtidos 110) conjunito de treinamento.

A fim de compreender concretamente como os resultados da Teoria do Aprendizado Estatístico possibilitan a construção de bons classificadores, na Seções 3.3 serão estudadas as Llácpuinas de Votores de Suporte e sua relação com a mininizaçäo do limite apresentado pela inequação 3.3

\subsection{Máquinas de Vetores de Suporte}

Conforme dito na Seção 3.1. as SVMs são unı família de algoritmos de aprendizado Sendo assim. são capazes de extrair conhecimento a partir de arnostras de clados. Elas operam de acordo com o paradigna supervisionado, aprendendo ma relaçăo funcional cutre os atributos (on calacterísticas) de entradat e saída por meio da apreciaçáo do exemplos rotulados. Vesta Scäo, será considerado apenass o problema do reconhecimento de padrão binário. Para tamo, a notaço apresentada no início da Seção 3.2 será adotada.

\subsubsection{SVMs Lineares para Dados de Classes Linearmente Separáveis}

As Mácuinas de Velores de Suporte lincares são originalmente classificadores que conscguem discriminar porfoitamonte aponas dados de classos linearmente separáveis. por moio da construção de um hiperplano ótimo. Émbora tenham uso muito restrito em aplicaçóes reais, os conocitos introduzidos nesta Seção são fundamentais para o descrnvolvimento do máquinas mais robustas.

Classificadores lineares ano aqueles capazes de separar pontos de classes distintab at ra- 
vés da utilizaçăo de un hiperplano ${ }^{3}$. Estas classes são ditas, então, linearmente separáveis. A Figura 3.2 ilıstra um conjunto de pontos bidimensionais linearmente separávcis e um liperplano separardor. Um hiperplano é definido pela Equação

$$
\langle\vec{w} \cdot \vec{x}\rangle+b=0
$$

onde $\vec{w}$ ć o vetor normal ao liperplano, e que define sua direção e o termo b é o bias, rssponsável mover o hiperplano em relação à origem. Para determinar a qual classe

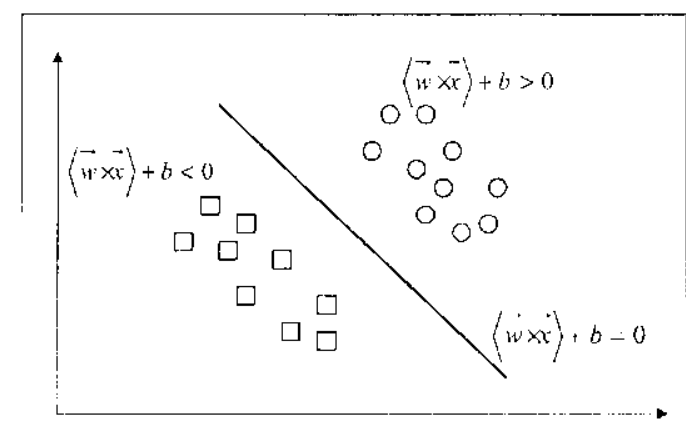

Figura 3.2: Conjunto linearmente separável, o hiperplano separador e a regra de decisấo. un ponto qualquer $\vec{x}$; pertence é suficiento verificar sua posição relativa ao hiperplano delinido por $(\vec{w}, b)$. Assim, tem-se a regra, ilustrada na Figura 3.2:

$$
\left\{\begin{array}{l}
y_{i}=+1 \text { se }\left\langle\overrightarrow{w^{\prime}} \cdot \overrightarrow{x_{i}}\right\rangle+b>0 \\
y_{i}=-1 \text { se }\left\langle\vec{w} \cdot \overrightarrow{x_{i}}\right\rangle+b<0
\end{array}\right.
$$

É importante enfatizar que para un conjunto de troinamento $S=$ $\left\{\left(\overrightarrow{x_{1}}, y_{1}\right), \ldots,\left(\overrightarrow{x_{N}}, y_{N}\right)\right\}$, lincarmente separável, pode haver diversos hiperplanos separadores. Este fato pode ser visualizado na Figura 3.3. Surge então a questão de qual hiperplano o algoritmo de treinamento da SVM deve escolher. A resposta é fornecida pela TAE.

Scgundo a TAE, deve-se sempre escolher o classificador com a melhor capacidade do generalização possível. on seja, aquele cujo Risco Esprerado seja baixo. Como não é possivel reduzir esta medida explicitamente, recorre-se ao limite fornecido pela Inequação 3.3, e busca-se minimizar o Risco Empírico e a dimensão VC.

\footnotetext{
${ }^{3}$ Segundo Cristianini e Shawe-Taylor (2000b), um hiperplano é um subespaço afín de dimonsăo $n-1$ que divide o espaço n-dimensional $\mathrm{cm}$ duas metades.
} 


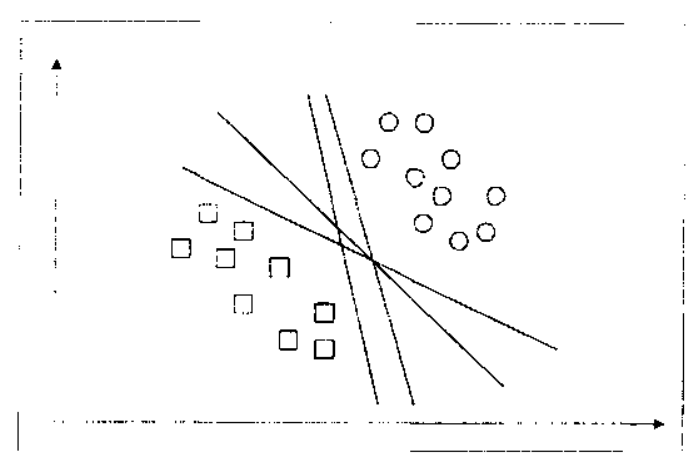

Figura 3.3: Vários hiperplanos são capazes de separar dados de classes lincarmento separáveis.

Manter o Risco Empírico zerado é trivial, sendo necessário para isso apenas determinar uma configuração de ( $\vec{u} . b)$ que classifique os elementos de $S$ perfoitamente, ou seja, que não cometa nenlnum cro de classificação no conjunto de treinamento.

Para minimizar a dimensão VC, faz-se uso de un resultado da TAE scgundo o qual a dimensão VC da classe dos hiperplanos canônicos é limitada superiormente por um terno inverso à margem de scparação entre os elementos do conjunto de treinamento $S$ (Lorenta. 2002). Portanto, consegue-se a menor dimensão VC possível maximizando-se a margem de separação.

Diz-se que um hiperplano está na forma canônica quando

$$
\min _{\overrightarrow{x_{i}} \in X}\left|\left\langle\vec{u} \cdot \overrightarrow{x_{i}}+b\right\rangle\right|=1
$$

Esta represent ação do hiperplano separador é adolada devido à padronizaçào, pois un mesmo hiperplano $(\vec{u}, b)$ pode ser representado por $(k \vec{w}, k b)$, para um escalar positivo $k \neq 0$, e também para facilitar os cálculos posteriores. Os pontos $\vec{x}$ que salisfazeru a Equação 3.7 sĩo denominados de vetores de suporte (SV, do inglês support vectors). Fles são os pontos mais próximos do hiperplano separador. OS SV são representados na Figura 3.4 por pontos mais escuros.

Pela definicäo de hiperplano canônico, percebe-se que a regra representada en 3.6 porle ser reserital como (Haykin. 1998):

$$
\left\{\begin{array}{l}
y_{i}=+1 \text { se }\left\langle\vec{w} \cdot \vec{x}_{i}\right\rangle+b \geq+1 \\
y_{i}=-1 \text { se }\left\langle u^{\dagger} \cdot \overrightarrow{x_{i}}\right\rangle+b \leq-1
\end{array}\right.
$$

P'ela Figura 3.4 ó possivel not ar também que os SV estão dispostos sobre hiperplanos paralelos ao hiperplano separador do tal forma que os SV positivos cstäo cm $\left\langle\vec{u} \cdot x_{i}\right\rangle+b-$ 


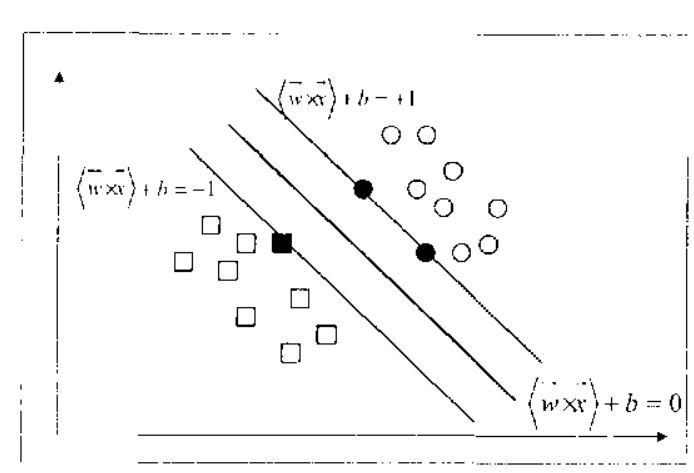

Figura 3.4: Hiperplanos canônicos e os vetores de suporte.

+1 e os negativos em $\left\langle\vec{u} \cdot \overrightarrow{x_{i}}\right\rangle+b=-1$. Isto também ó conseqüôncia da definição de hiperplanos canônicos.

A margem de separação $M$ é definida como a projeção, no vetor $\vec{w}$, da distância entre quaisquer dois SV pertencentes a classes diferentes (Haykin, 1998). A Figura 3.5 ilustra un exemplo de margem M para um conjunto de dados.

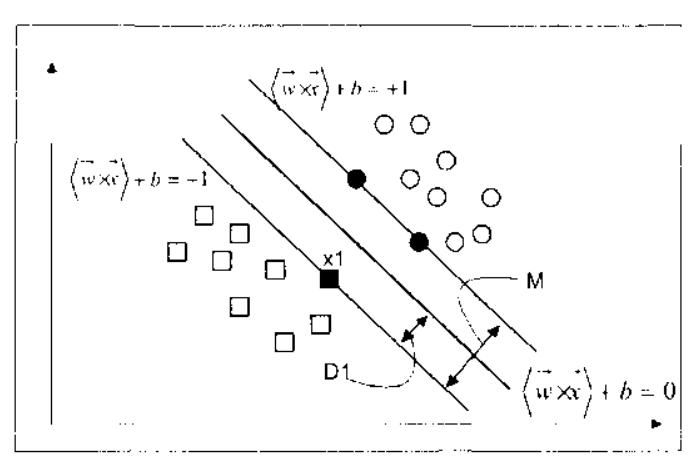

Figura 3.5: Margem de separação.

Para calcular a margen $M$, utiliza-se a nogăo de distância $D$ entre um ponto $\overrightarrow{x_{p}}$ e um hiperplano $\langle\vec{u} \cdot \vec{x}\rangle+b=0$, definida pela Equação 3.9(Cristianini e Shawe-Taylor, 2000b):

$$
D=\frac{|\langle\vec{u} \cdot \vec{x}\rangle+b|}{|\vec{w}|}
$$

onde $\|\cdot\|$ é o símbolo que representa a norma.

Assim, a distancia $D_{1}$ entre um vetor de suporte qualquer $\overrightarrow{x_{1}}$ e o hiperplano $\langle\vec{w} \cdot \vec{x}\rangle+$ $b=0$, mostrados na Figura 3.5, ć

$$
D_{1}=\frac{M}{2}=\frac{|\langle\vec{w} \cdot \vec{x}\rangle+b|}{\|\vec{w}\|}=\frac{1}{\|\vec{w}\|}
$$

Da. Fquação 3.10. conclui-so que $M=2 /\|\vec{w}\|$ e que, quanto menor o valor de $w$, 
nator o valor da margem. Portanto, minimizar $\vec{u}$ ó imperativo para a maximizaçào da margem $\mathrm{M}$ e, conseqüentonente, para a diminuição da dimonsäo VC.

O hiperplano associado à menor margem de separação obtida para o conjunto de treinamento é denominado de ótimo, representado pelo par $\left(u^{*}, b^{*}\right)$. e encontrá-lo é de responsabilidade do algoritmo de aprendizado das SVMs. Formalmente, pode-se re-escrever a tarefa de troinamento como:

$$
\begin{cases}\text { Mininizar: } & \|\left.\vec{w}^{\prime}\right|^{2} \\ \text { Sujeito } a: & y_{i}\left(\left\langle\vec{w} \cdot \overrightarrow{x_{i}}+b\right)-1 \geq 0, \quad i-1, \ldots, N\right.\end{cases}
$$

onde pode-se ressaltar que a funçuo objetivo que se deseja otimizar é monótona e portanto minimizar o $\|\vec{w}\|$ original é equivalente à minimização de $\mid \vec{w} \|^{2}$; c a restrişão imposta cm 3.11 fia verdade, a Regra 3.8 escrita de forma simplificada.

Este é um problema clássico de otimização, onde o termo gue se deseja minimizar ć quadrático e convexo e as restrições são lineares. Ele ć conhecido como programaçio quadrática convexa. Una técnica padrão para a sua resolução é o método dos multiplicadores de Iagrange. Inicialmente, deve-se definir a função do Lagrango (Cristimini Shawe- Taylor, $2000 \mathrm{~b})$ :

$$
L(\vec{w}, b, \vec{a})=\frac{1}{2}\|\vec{w}\|^{2}-\sum_{i=1}^{N} \alpha_{i}\left(y_{i}\left(\left(\vec{w} \cdot \overrightarrow{x_{i}}+b\right)-1\right)\right.
$$

onde os $\alpha$, são denominados multiplicadores de Lagrange. A solução para este problema ó chamada de ponto de sela ótimo, representada por $\left(\vec{u}^{*}, b^{*}, \vec{\alpha}^{*}\right)$. onde $\vec{\alpha}^{*}=\left\{\alpha_{1}^{*}, \ldots, \alpha_{N}^{*}\right\}$. Para oncontrar seu valor, faz-se uso do teorema do Karush-Kuhn-Tucher (KKI) (Cristianini e Shawe- Taylor, 2000) ), que fornece as condições necessárias e suficientes para a otinização da Equação 3.12 .

A primeira condição é (que as derivadas parciais de $L$ com relaçäo a $\vec{u}^{*}$ e $b^{*}$ devem ser zeradas, Assim

$$
\begin{aligned}
& \frac{\partial L}{\partial \vec{w}^{*}}=0, \text { ou } \vec{u}^{*}=\sum_{i=1}^{N} \alpha_{i} y_{i} \vec{x}_{i} \\
& \frac{\partial L}{\partial l^{*}}=0, \quad \text { ou } \sum_{i=1}^{N} \alpha_{i} y_{i}=0
\end{aligned}
$$

As outras condições $\mathrm{KKT}$ são:

$$
\begin{cases}a_{i}^{*}\left\{\left(y_{i}\left(\left\langle\vec{w} \cdot \overrightarrow{x_{i}}+b\right)-1\right)\right\}=0,\right. & \text { para } \mathrm{i}=1, \ldots, \mathrm{N} \\ x_{i}^{*} \geq 0, & \text { para } \mathrm{i}=1, \ldots, \mathrm{N} \\ y_{i}\left(\left\langle\vec{u} \cdot \overrightarrow{x_{i}}+b\right)-1 \geq 0,\right. & \text { para } \mathrm{i}=1, \ldots, \mathrm{N}\end{cases}
$$


Neste momento, ó possivel definir o ponto de sela ótimo de $L$ através das condiçoes KLT mencionadas. Fntretanto. é conveniente expressar o Problema 3.11 cm outra representação, denominada dual. A razão para isto é que nesta, as restriçốs são mais simples. facilitando o processo de otimizacão. e também permitindo trabalhar diretamente em ospaços de alta dimensionalidade. por meio da utilização de kernels, conforme será visto ná Subseção 3.3.3.

Para exprimir o problema em sua representação dual é necessário substituir os resultados obtidos em 3.13 na função de Lagrange definida em 3.12. Com isso, tem-se:

$$
\begin{cases}\text { Maximizar: } & Q(\vec{\alpha})=\sum_{i=1}^{N} \alpha_{i}-\frac{1}{2} \sum_{i=1}^{N} \sum_{j=1}^{N} \alpha_{i} \alpha_{j} y_{i} y_{j}\left\langle\overrightarrow{x_{i}} \cdot \overrightarrow{x_{j}}\right\rangle \\ \text { Sujeito a: } & \alpha_{i} \geq 0, \quad i=1, \ldots, N \\ & \sum_{i=1}^{N} \alpha_{i} y_{i}=0\end{cases}
$$

Novamente, aplica-se as condições KKT para encontrar a solução ótima de 3.15, representada por $\vec{\alpha}^{*}$. Os valores de $\vec{u}^{*} \mathrm{c} b^{*}$ com relação a $\vec{\alpha}^{*}$ são assim definidos:

$$
\begin{gathered}
\vec{w}^{*}=\sum_{i=1}^{N} \alpha_{i}^{*} y_{i} \overrightarrow{x_{i}}=0, \text { para } \mathrm{i}=1, \ldots, \lambda \\
b^{*}=\frac{1}{N_{S Y}}\left(\sum_{s=1}^{N_{S Y}}\left(\frac{1}{y_{S}}-\left\langle\overrightarrow{x_{s}} \cdot \overrightarrow{u^{*}}\right\rangle\right)\right), \text { para } s=1_{,}, \ldots, N_{S Y}
\end{gathered}
$$

onde $N_{S V}$ representa o número de SV do conjunto de treinamento.

É importante salientar que na Equação 3.16 grande parte dos multiplicadores de Lagrange $\alpha_{i}^{*}$ tem valor zero. Os pontos $x_{i}$ com valores $\alpha_{i}^{*}$ diferentes de zero correspondem ans vetores de suportc. Eles são, portanto, os pontos mais determinantes do conjunto de treinamento para a classificação. De lato, com os resultados das equaçócs 3.16 e 3.17 , pode-se escrever o classificador final $\int$ como (com base $\mathrm{cm} \mathrm{3.6):}$

$$
f(\vec{x})=\left\{\begin{array}{l}
+1 \text { se } \sum_{i=1}^{N_{S W}} y_{i} \alpha_{i}^{*}\left\langle\vec{x} \cdot \overrightarrow{x_{i}}\right\rangle=0>0 \\
-1 \text { se } \sum_{i=1}^{N_{S V}} y_{i} \alpha_{i}^{*}\left\langle\vec{x} \cdot \overrightarrow{x_{i}}\right\rangle-0<0
\end{array}\right.
$$

\subsubsection{SVMs Lineares para Dados de Classes Não-linearmente Separáveis}

Na Subseçào 3.3.1, foi estudada a forma como as SVMs lincares lidan com dados de classes linearmente separáveis. $\Lambda$ exposição foi valiosa no sentido de introduzir conceitos 
importantes, como margons e representação dual do problema, por exmplo. Entretanto, para fins práticos, a abordagem vista ali não e de grande valia. Isto ocorre simplesmente devido à constatação de que, na maioria dos problemas reais, os dados não são bom comportados, com elementos de classes distintas sendo perfeitamente discriminados por um hiperplano.

Na verdade, em muitas aplicações, seja pela própria natureza do domínio on por ruído nos dados, acontece a sobreposição de classes, com elementos de uma classe confundindose com elementos de outra. Nestes casos, não é possível utilizar um hiperplano de separe perfeitamente os pontos. Assim, diz-se que os dados são não-linearmente separáveis. Unı conjunto de dados não-linearmente separável é mostrado na Figura 3.6

A dificuldade on utilizar uma SVM linear para classificar dados não-linearmente separáveis decore do fato de a restricão $y_{i}\left(\left\langle\vec{u} \cdot \overrightarrow{x_{i}}+b\right) \geq 1\right.$, dada cm 3.11 , não poder ser respeitada sempre. Por exemplo, considere o conjunto de treinamento represcntado na Figura 3.6. Nela, vê-se que o ponto $x_{1}$ está circundado por pontos da classc oposta. Neste caso, não existe uma configuração $(\vec{u}, b)$ de hiperplano separador que satisfaça a restrição 3.11. pois esta é muito rígida.

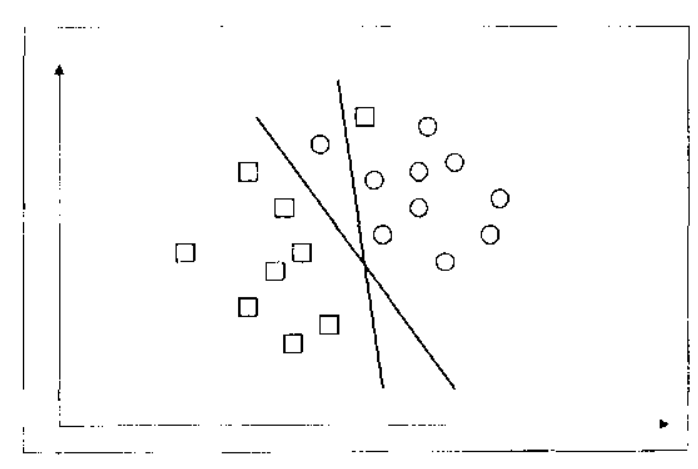

Figrura 3.6: Conjunto de dados de classes não-lincarmente separáveis.

Una forma de contornar este problemá ó a introdução de un conjunto de variáveis do folga $\left\{\xi_{1}, \ldots \xi_{i}\right\}, i=1, \ldots, N$, que flexibilizarid 3.11 , permitindo que erros de classifica ão ocorressem. A nova restrição é assim formuladia (Cristianini e Shawe-Taylor, 2000b):

$$
y_{i}\left(\left\langle\vec{u} \cdot \overrightarrow{x_{i}}+b\right) \geq 1-\xi_{i}, \text { para } i=1, \ldots, N \circ \xi_{i} \geq 0\right.
$$

Lima variável de folga $\xi_{\text {i }}$ mede o quão afastado um ponto $x_{i}$ está do hiperplano contendo os vetores de suporte de sua classe $(\langle\vec{w} \cdot \vec{x}\rangle+b= \pm 1)$. Assim, quanto maior seu valor, pior classificado o ponto ostá. O clemento $x_{1}$ da Figura 3.7, por exemplo, está melhor 
classificado que o elemento $x_{2}$, e, portanto, tem o valor $\xi_{1}$ associado menor. Se todos os pontos do conjunto de treinamento tiverem $\xi_{i}=0$, diz-se que a classificacão é perfejta

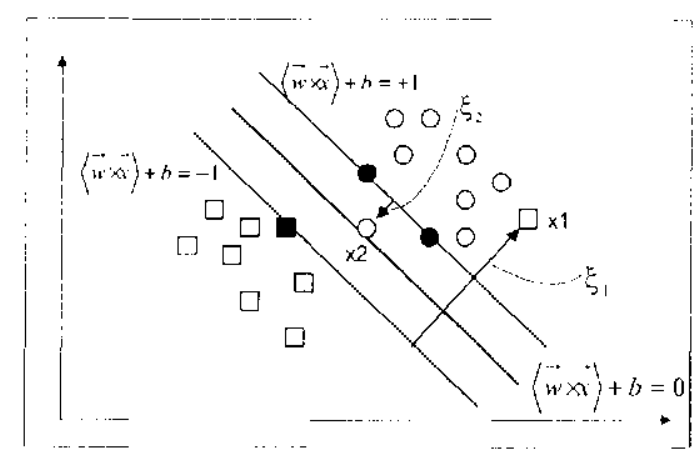

Figura 3.7: Variáveis de folga $\xi_{i}$

Conformo visto na Subsecão 3.3.1. o algoritmo de treinamento das SVMs lincares tem por objetivo encontrar o hiperplano associado com a maior margem de separagão possível. Para o caso de dados de classes não-linearmente separáveis, é necessário tambén que o algoritmo minimize os valores de $\xi_{i}$. Assim, o problema pode ser formulado da seguinto forma:

$$
\begin{cases}\text { Minimizar: } & \|\vec{w}\|^{2}+C \sum_{i=1}^{N} \xi_{i} \\ \text { Sujeito a: } & y_{i}\left(\left\langle\vec{w} \cdot \overrightarrow{x_{i}}+b\right)-1 \geq 0, \quad i=1, \ldots, N\right.\end{cases}
$$

onde Cé o parâmetro de penalidade definido pelo usuário. Un valor grande de $C$ corresponde a atribuir uma grande penalidade a erros de classificação durante o treinamonto.

Como o Problema 3.11, cste também é de programação quadrática e pode ser resolvido através dos métodos comentados na Subseção 3.3.1. Apenas algumas alteraçōes precisam ser salientadàs, como ná representação dual do problema:

$$
\left\{\begin{array}{cl}
\text { Maximizar: } & Q(\vec{\alpha})=\sum_{i=1}^{N} \alpha_{i}-\frac{1}{2} \sum_{i=1}^{N} \sum_{j=1}^{N} \alpha_{i} \alpha_{j} y_{i} y_{j}\left\langle\overrightarrow{x_{i}} \cdot \overrightarrow{x_{j}}\right\rangle \\
\text { Sujeito a: } & 0 \leq \alpha_{i} \leq C, \quad i=1, \ldots . N \\
& \sum_{i=1}^{N} \alpha_{i} y_{i}=0
\end{array}\right.
$$

A última restriça de 3.21 é diferente daquela vista para o caso lincarmente separável, pois os valores de $\alpha_{i}$ são limitados por $C$ (no problema 3.15 pode-so considerar $C=\infty$ ) O procedimento para encoutral os valores ótimos de $\overrightarrow{w^{*}}$ e de $b^{*}$ ć o mesmo e a forma como o classificador final é representada ó igual à representação utilizada na Equação 3.18. 


\subsubsection{SVMs Não-lineares}

Na Subseção 3.3.1. foram estudados diversos aspectos das SVMs lineares apenas para o caso de dados de classes linearmonte scparáveis. Na Subseção 3.3.2. foi possível construir classificadores lineares capazes de superar esta limitação, de forma a trabalhar con classes superpostas. Nesta Subseção, utiliza-se os recursos do arcabouço térico estruturado anteriomente para conseguin lidar com clementos de classes que não podem ser discriminados dirctamente através de um hiperplano.

Para exemplificar, considere o conjunto de pontos bidimensionais da Figura 3.8. E trivial perceber que não é possível separar os elementos da classe círculo dos clementos da classe quadrado simplesmente com a utilização de um hiperplano.

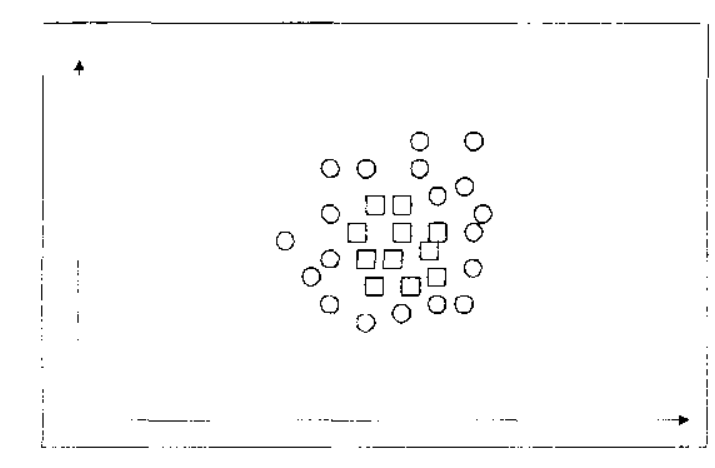

Figura 3.8: Conjunto de dados nâo-linear

A idéia implementada pelas máquinas de vetores de suporte não-lineares é transformar os elementos de seu espaço de entrada original (o input space) para outro (de alta dimensionalidade, potencialmente infinita), conhecido como espaço de características (o fealure space) e tentar projetar un classificador neste espaco.

A motivação para esta estratégia foi fornecida por Cover (Haykin, 1998), quando afirmon que se a transfornação do espaço de cntrada original para o espaço de característicias fosse não-lincar e a dimensão do espaço de características fosse suficientemente grande. entăo, com alta probabilidade, os dados scriam linearmente separáveis no novo espaço. Desta forma, para realizar a classificação de um conjunto do pontos como o representado na Figura 3.9. ć sufficiente realizar o mapeamento dos elementos entre os espaços através de unna funģa não-linear $\Phi(\vec{x}): R^{M} \rightarrow R^{M \prime}, M \ll M^{\prime}$ : representada na Figura 3.9.e aplicar o algoritmo de aprendizado da Subseção 3.3.2 para a geração do unn classificador. 


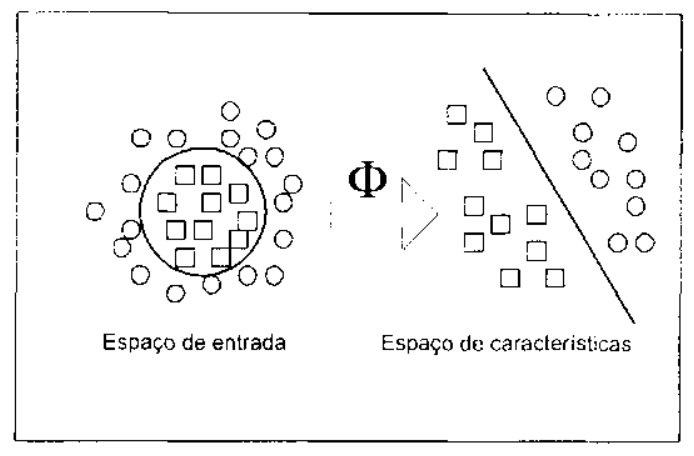

Figura 3.9: Mapeanento Espaço do entrada - Espaço de saída.

Assim, substituindo $\overrightarrow{x_{i}}$ por $\phi(\vec{x})$ no problema 3.21 , tem-se:

$$
\begin{cases}\text { Maximizar: } & Q(\vec{a})=\sum_{i=1}^{N} \alpha_{i}-\frac{1}{2} \sum_{i=1}^{N} \sum_{j=1}^{N} \alpha_{i} \alpha_{j} y_{i} y_{j}\left\langle\phi\left(\overrightarrow{x_{i}}\right) \cdot \phi\left(\overrightarrow{x_{j}}\right)\right\rangle \\ \text { Sujcito a: } & 0 \leq \alpha_{i} \leq C, \quad i=1, \ldots, N \\ & \sum_{i=1}^{N} \alpha_{i} y_{i}=0\end{cases}
$$

É importante notar que pode ser extremamente custoso calcular os $\phi\left(\overrightarrow{x_{i}}\right)$ durante a fasc de treinamento da SVM. Entretanto, graças à representação dual de 3.22 , que expressa os dados do conjunto de treinamento apenas na forma de produto escalar, este esforço é poupado pela utilizaçāo de kernels.

Os kernels são funções definidas segunda as condiçōes de Mercer (Cristianini o ShawcTaylor, 2000b) que recebcm dois pontos $\vec{x}$ e $\vec{z}$ do espaço de cntrada o computam o produto escalar $\langle\phi(\vec{x}) \cdot \phi(\vec{z})\rangle$ no espaço de características, conforme descrito em 3.23 :

$$
k(\vec{x}, \vec{z})=\langle\phi(\vec{x}) \cdot \phi(\vec{z})\rangle
$$

$\Lambda$ ssim, nẫo 6 necessário preocupar-se com a forma explicita de $\phi$, o que garante às SVMs grande vantagem computacional. Alguns dos kemels mais utilizados são mostrados na Tabela 3.1. É importante ressaltar que a escolha do kernel é dopendente do domínio da aplicação. Fm todos os expcrimentos realizados neste trabalho, será. utilizado o kernel linear, que tem sido amplamente utilizado na classificação de amostras de tecido com base em dados de expressão gênica. 


\begin{tabular}{|c|c|}
\hline Função kernel & $K\left(\overrightarrow{x^{2}}, \overrightarrow{x_{i}}\right), i=1, \ldots, N$ \\
\hline kernel Linear & $K\left(x^{*}, \overrightarrow{x_{i}}\right)=\left\langle\vec{x} \cdot \overrightarrow{x_{i}}\right\rangle$ \\
\hline kernel Polinomial & $K\left(\vec{x}, \overrightarrow{x_{i}}\right)-\left(\left\langle\overrightarrow{x_{i}} \cdot \overrightarrow{x_{i}}\right\rangle+1\right)^{d}$ \\
\hline kernel Ganswiano & $K\left(\vec{x}, \overrightarrow{x_{i}}\right)=\exp \left(-\left\|\vec{x}-\cdots x_{i}\right\|\right)^{2} / 2 \sigma^{2}$ \\
\hline kernel Signóide & $K\left(\vec{x} \cdot \overrightarrow{x_{i}}\right)=\tanh \left(\beta_{0}\left\langle\vec{x} \cdot \overrightarrow{x_{i}}\right\rangle+\beta_{1}\right)$ \\
\hline
\end{tabular}

Tabela 3.1: Principais kernels

\subsection{Considerações Finais}

Neste Capitulo, foram revistos os fundamentos das Máquinas de Vetores de Suporte uma classe de algoritmos de aprendizagem que tem obtido grando sucesso em diversas aplicaçöes. Segundo Smola o Schoolkopf (2002), as principais vantagens das SVMs são:

- Boa capacidade de goneralização: conforme visto. graças à implementação dos princípios da Teoria do Aprendizado Estatístico apresentada na Seção 3.2, as SVMs conseguem minimizar a probabilidado de erros quando do confronto com dados näo vistos durante a fase de treinamento:

- Eficiencia computacional: no decorrer da Seçäo 3.3, foi visto como conceitos como representaçào dual e kernels ajudam a manter os algoritmos das SVXs tratárcis rnesmo para problemas mais complexos;

- Robustez em grandes dimensões: as SVMs são tolerantes a problemas comumente encontradas en outros tipos de algoritmo de AM quando expostos a dados de grande dimensão, como o overfitting e a degradação acentuada de desempenho.

Além de todos estes pontos positivos, diversos estudos sugerem que as SVMs podem se beneficiar fortemente de técnicas de redução de dimensionalidade de dados (Guyon et al., 2002) (Weston ct al., 2000) (Rakotomamonjy, 2003). Assim, no Capítulo 4, será estudado uma das abordagens mais comuns de redução de dimensionalidade. a seleção de características. Serão também aprescutados estudos envolvendo técnicas do scleção de características desenvolvidas exclusivamente para as SV.Ms. 
Capítulo 4

\section{Seleção de Características em Dados de \\ microarray}

\subsection{Considerações Iniciais}

Recentemente, os experimentos de microarrays tên auxiliado biólogos e pesquisadores a comprecnder melhor a dinamica colular e seus relacionamentos com estados patológicos. Dentre as aplicaçoes mais comuns desta tecnologia, pode ser citada a classificação de novas amostras de tecidos a partir de sua descrição genética, ntilizando-se algoritmos de A. De fato, diversos estudos mostraram a eficácia dessa abordagem na classificação de doenças severas, como o câncer (Inza ct al., 2004) (Xing, 2003) (Mukherjee, 2003). Em comum, esses trabalhos destacam que lidar com poucos genes é primordial para uma maior qualidade dos resultados e para a compreensão do fenômono considerado.

Para reduzir o número de genes com un mínimo de perda de informação, podo-so utilizar ténicas de redução de dimensionalidade. Há, basicamente, 2 abordagens para isso: a extração de características o a seleção de características. A primeira consiste em rriar novas características a partir de transformações e combinaçoes das características existentes. Alguns trabalhos mostram a utilidade desta abordagem em dados do microarray (Nguyen, 2005) (Dragomir et al., 2004). A segunda consiste en selecionar um subconjunto ótimo de características. segundo algum critério pré-estabelecido. En experimentos de expressão gênica, esse subconjunto é composto de genes que podern ser analisados posteriormente em laboratório para entender seu relacionamento com o problema em estudo. Sendo assim, técnicas desta abordagem tên sido preferida.

Teste Capitulo, ó consiclerada a utilização de técnicas de seleção de características aplicadas a bases de dados de expressão gênica. Inicialmente, as motivações para isso são fornecidas e o problema é descrito formalmente. Posteriormente, as abordagens de seleção são apresentadas e as técnicas utilizadas neste trabalho são discutidas. Fm seguida, são 
propostas 2 estratégias bascadas em Algoritmos Genćticos para selecionar subconjuntos de características. Por firn, algumas consideraçoes são tocidas.

\subsection{O Problema da Seleção de Características}

O objetivo de AM é extrair conhecimento de forma automática de um conjunto de dados Michalski et al. (1983). Para isso, o algoritmo de AM muitas vezes faz, uso de exemplos rotulados, representados por vetores de características, e tenta aprender uma funçào de mapeamento entre os exemplos de entrada e suas saídas desejadas. Este aprendizado ocorre na chamada fasie de treinamento do algoritmo, ao final da qual um classificador é induzido.

Teoricamente, quanto mais características forem utilizadas para representar os exemplos, mais informação estará disponível para o algoritmo de A.M e portanto melhor será o desempenho do classificador Koller e Sahami (1996). Entretanto, restrições práticas sugerem que traballar com un conjunto reduzido de características pode ser benélico em diversos aspectos.

Primeíro, em aplicaçoses reais, geralmente observa-se que quanto maior o número de características, maior a quantidade de exemplos necessária para construir um classificador de bom desempenho. Esse fenômeno é conhecido como maldição da dimensionalidado. Jain ct al. (2000). Em alguns casos, o número requerido de exemplos pode ser exponencial cm relação ao número de características Bishop (1996). Em muitas situações, um conjunto menor de características pode melhorar o desempenho do classificador, devido aos efeitos da quantidade finita de exemplos de treinamento Jain e Chandrasekaran (1982).

Scgundo, em alguns domínios, é comum que a maioria das características não seja informativa para a distincäo entre as diferentes classes Xing (2003). Isto ocorre principalmente por serem irrelevantes ou redundantes ou apresentarem níveis elevados do ruído. Assim, o aprendizado pode ser realizado mais eferivamente desconsiderando-se tais características. Além disso, o uso de mais características implica cm maior custo de aquisição e análise dos dados, além do aumentar o tempo de processamento dos algoritmos de AM.

Terceiro. em certos casos, a visualização e compreensão dos dados é tão imporiante quanto o bom desempenho do classificador. Um exemplo disso são os problemas de diagnóstico médico utilizando dados de expressão gênica. A identificação de genes relacionados 
com o fenótipo em estudo é de grande interesse prático. Biólogos e pesquisadores podem examinar os genes seleciondos para corroborar descobertas recentes o sugerir novas oportunidades de exploração.

Para realizar a redução de dimensionalidade, os métodos do Soleção de Característicn (SC) estão entre os mais utilizados. O princípio básico dos métodos de SC consiste en dado um conjunto de $n$ características, selecionar um subconjunto de tamanho $k$ tal que o erro de classificação tenha a maior redução possível om relação ao conjunto completo Jain et al. $(2000)$. Formalnente, a SC pode ser definida pelo seguinte procedimento: dado um conjunto do excmplos $S_{n}\left(S_{n} \subset R^{n}\right)$, onde cada exemplo $s_{n}\left(s_{n} \in S_{n}\right)$ é um vetor de $n$ raracturisticas o sejam $C_{k}$ o conjunto de todas as combinaçós de $k$ caracteristicas $(k<n)$ do conjunto original de $n$ características e $S_{n_{c} k}$ a projeção do conjunto $S_{n}$ na combinação de características $c_{k}$, selecionar um subconjunto de $c_{k} \in C_{k}^{y}$ tal que a função $J\left(S_{n_{k} k}\right) \operatorname{seja}$ maximizada onde $J(\cdot)$ c uma função critério que assume maiores valores para melhores subconjuntos de características. Conforme será visto posteriomente, diversos critérios podem ser adotados, dependendo da estratégia de SC considerada.

Este trabalho dará ênfase a métodos de SC no contexto de dados de expressão gênica provenientes de experimentos de microartays. Este tipo de dados possui algumas propriedades que tomam a aplicąão de $\mathrm{SC}$ possível e muito desejável. A saber:

1. Alta dimensionalidade: os experimentos de microarray são projetados para medir a expressão de grando quantidade de genes simultancamente. Tipicamente, milhares de medições são consideradas. Na classificação de tocidos, os genes correspondem às características que representam cada amostra

2. Características irrelevantes: os estudos sugerem que apenas uma pequena parcela de genes está envolvida en un fenomeno biológico específico Jaeger et al. (2003). Sendo assim, para realizar a distingão entre anostras de diferentes estados patológicos utilizando expressão gênica, é suficiente focar apenas nos genes mais informativos.

3. Características redundantes: em alguns casos, é possível que liaja unna alta correlação entre os genes. Isto geralmente ocorre quando os genes estão na mesma via metabólica, são co-expressos ou são do mesmo cromossomo Jaeger et al. (2003). Na maioria dos casos, a eliminação de características muito correlacionadas com outras não influencia o desempenho do classificador.

4. Dados com ruido: os experimentos de microarrays estão sujeitos a diversas fontes do 
rukto. As mais commus se devem às técnicals de processamento de inagem Gibsono Muse (2004). que podem distoreer a inagem do microarray: à variaçós biológicas e ans protocolos experimentais empregados Tu et al. (2002).

5. Poucos dados: atualmonte, as bases de dados de microarray disponíveis publicamente são compostas do poucas amostras de tecido, goralmente na ordem de dezenas. A principal razão pra isso é o alto custo da tecnologia e a dificuldade de obtenção do amostras clínicas suficientes, o que impede a realização de mais experimentos Kim e. Park $(2004)$

A seguir, as características gerais dos algoritmos de SC empregados na literatura serão apresentadas. A partir deste ponto e até o fim do Capítulo, os cemos gene o característica scrão ntilizados indistintamente. Então o problema de solecionar subconjuntos de genes devo ser entendido como $u$ problema de SC.

\subsection{Características dos Algoritmos de SC}

Pode-se considerar a selecaro de caracteristicas como un probleme de busca. Neste, torlas aus combinaf̧ós possíveis das caracteristicas correspondem ao espaço de busca. A Figura 1.1 ilnstra um grafo representando um domínio com quatro características. Cada nó do grafo significa um possível subconjunto de características. O círculo escuro indica que a característica está presente e círculo branco indica que ela está ausente.

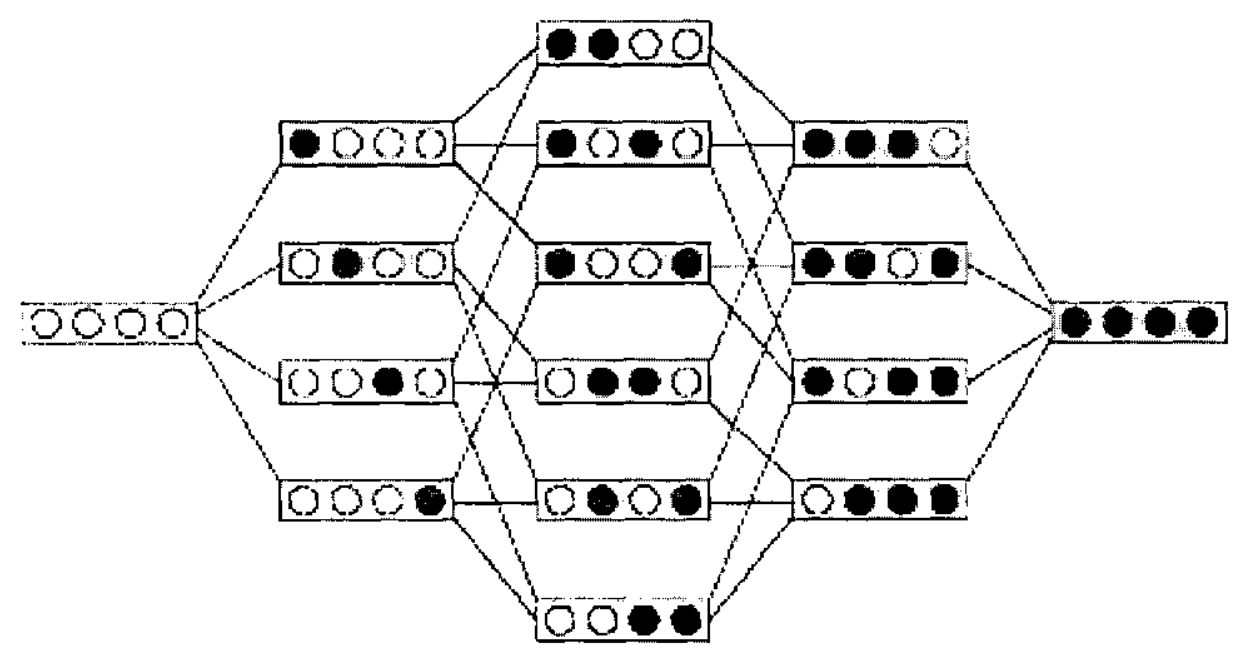

Figura 4.1: Seleção de características como um problema de busca Blum e Langley (1997)

Neste contexto de busca, J3hm e Langley (1997) definiram quatio aspectos que devem 
ser considerados no tratar o problema da selecäo do características. São oles: ponto(s) do início da busca e geração dos subconjuntos. organizaçăo da busca. estratécia de avaliaça "o critério cic parada.

\subsubsection{Ponto(s) de Início da Busca e Geração dos Subconjuntos}

Motoda ( lin (2002) dostacam as seguintes formas de geraçion de subcomjuntos:

1. Geração para trás (backward generation). A busca tem início pelo conjunto contendo todas as características (nó mais a direita do grafo da Figura 4.1) e em seguida vai-se removendo as características para formar novos subconjuntos. Se uma caractoristica por voz for removida. tem-se a chamada selecão seqüncial para trás.

2. Geraçāo adiante (forward generation). () conjunto inicial de característicass é vazio (nó mais a escuerda do grafo da Figura 4.1) e. a cada nível do grafo, novas aracterísticas são acrebcidas. Se una característica for acrescida por vo\% tem-se a chamarla seleção soqüencial adiante

3. Geração bidirecional (bidirectional gencration). A busca tem início tanto pelo conjunto de características vazio quanto pelo conjunto contendo todas as características o os subconjuntos vão sendo gerados atravós da remoção e da adição de características, do acordo com as extremidades do grafo.

4. Geraçāo raudômica (random generation). Esta abordageın ć caractericada pelas escollaws aleatórias do ponto inicial e da decisĩo de remover on adicionar as caracteristicas.

\subsubsection{Estratégia da Busca}

Tendo definido o ponto inicial da busca e a forma da geraç̃o dos subconjuntos, ó necessário definir que algoritmo utilizar para percorrer o grafo. Há várias abordagens. Liu c Motoda Lin a Motoda (1998b) resumiran os algoritmos nas seguintes categorias:

1. Busca completa. Por busca completa entende-se aquela que conscguc avaliar todos os subconjuntos ótimos (de acordo com algum critério de avaliação), caso laija mais de um. A princípio, a única mancira que garantir isso é realizando uma busca exaustiva, onde todos os nós sãu visitados. Entretanto caso o critório de avaliaçăo satisfaca certas propriedades, conno ser uma função monotônie ${ }^{1}$ : pode-se encontrar

\footnotetext{
${ }^{\prime}$ lima funçäo $f(x)$ é dita monolonicia se $f\left(x_{1}\right) \geq f\left(x_{2}\right)$ sempre yue $x_{1} \geq x_{2}$
} 
um conjunto ótimo sem ser necessário visitar todos os nós do grafo.

2. Busca heurística. $\Lambda$ utilização de leurísticas ${ }^{2}$ pode diminuir dramaticamente a complexidade da busca, e ainda assim apresentar resultados satisfatórios. Fntretanto, diferente da categoria anterior, os algoritmos desta não podem garantir que a soluçâo fornecida seja ótima, embora geralmente bons subconjuntos de características sejam encontrados.

3. Busca não-determinística. Este tipo de busca está intimamente relacionado com a geração randômica vista na Seção 4.3.1. Esta abordagem apresenta duas características principais: nào é nccessário esperar até que a busca termine para se cncontrar uma solução adequada e não é possível saber quando o subconjunto de características ótimo vai aparecer ( apenas sabe-se que um subconjunto é melhor que outro se ambos já tiverem sido visitados).

\subsubsection{Estratégia de Avaliação}

Un dos aspectos centrais de todo algoritmo de SC é definir qual sua estratégia para avaliar um dado subconjunto de características. Em Lin e Motoda (1998b), 2 categorias de critérios de avaliação são destacadas, baseado em como o critério se relaciona com o algoritmo de aprendizado:

1. Independente. Os critérios independentes tentam avaliar quão boa é uma característica ou um conjunto de caracteristicas sem o envolvimento do algoritmo de aprendizado no processo. Eles estão relacionados con o filtros, que serâo vistos na Seçĩo 4.4 .

2. Dependente. Os critérios dependentes tentam avaliar quäo boa é uma característica ou un conjunto de características analisando o desempenho de um algoritmo de aprendizado aplicado às características escolhidas. Ou seja, o próprio desempenho do algoritmo de aprendizado é utilizado como cricério para avaliar o conjunto de características. Estes critérios estäo relacionados com a abordagem de wrappers, que será vista na Scção 4.5

${ }^{2}$ Heurísticas corresponde a um conjunto de regrass e métodos que conduzen à resoluçăo de un problema. 


\subsubsection{Critério de Parada}

Quando se utiliza a busca exaustiva, o algoritmo do seleção de características pára qumulo todos os nós tiverem sido visitados. Quando outros tipos de busca forem utilizados, 6 necossário definir algum critério para que o algoritmo pare sua execução. Alguns critérios sugerirlos são (Liu \& Motoda, 1998a):

1. Parar (quando um nimnero pré-definido de características é alcançado:

2. parar quando nem a adiço do novos características nem a remoção das características atuais melhoram a avaliaçào do subeonjunto:

3. parar quando o desempenho comegar a se deteriorar ou

4. parar quando se alcança a extremidade oposta do grafo e, entäo, escolhor o melhor subconjunto, segundo algum! critínio pré-cstabelecido.

\subsection{Filtros}

Os filtros são métodos que selecionan subconjuntos de características do forma independente do algoritmo de $\Lambda \mathrm{M}$ utilizado (John ot al., 1994). Eles agem em uma etapa de pré-processamento dos dados, aplicando algum tipo de heurística haseada nas propriedades gerais do conjunto de dados para descartar on filtrar as características redundantes e/ou irrelevantes. Uma característica ć considerada redundante se uma ou mais caractelísticas são fortemente contalacionadas com ela (Hall. 1999).

Existem várias defiucecose de relevancia para ma raracterística. A mais utilizada se deve a John et al. (1994). Eles definiran formalnuente 2 grans de relevâneia. Una característica $x_{7}$ c considerada fortemente relevante se a distribuicaro de probabilidade dos valores das classes, dado o conjunto completo de característieas $S$, modificar-se quando $x_{i}$ for removida. A característica $x_{i}$ ć considerada fracumente relevante se cla não for fortemente relovante e se a distribuição do probabilidade dos valores das classes, dado um subconjunto de características $s(s \subset S)$. do qual $x_{i}$ é membro, modificar-se quando $x_{i}$ for removida. 'Todas as características que näo são nem forte nem fracamente relovantes, săo consideradas irrelevantes.

Escluematicamente, a abordagen de filtros pode ser representada pola Figura 4.2. Nela, alguma estrategia ó adotada para realizar a busca no espaco de possiveis subconjuntos de características, utilizando os exemplos do conjunto do treinamento. Cada subconjunto 
comsiderado é avaliado de acordo com uma henrística pré-estabelecida. O valor da heurística serve para definir quão bom ó o subconjunto e também para guiar a busca. Ao final do processo de SC o subconjunto solecionado é utilizado para reduzir a dimensionalidade dos conjuntos de dados (treinamento e teste). Por fim, o conjunto de treinamento é utilizado pelo algoritmo de AM para construir um classificador, que será utilizado para. classificar os exemplos do conjunto de testes.

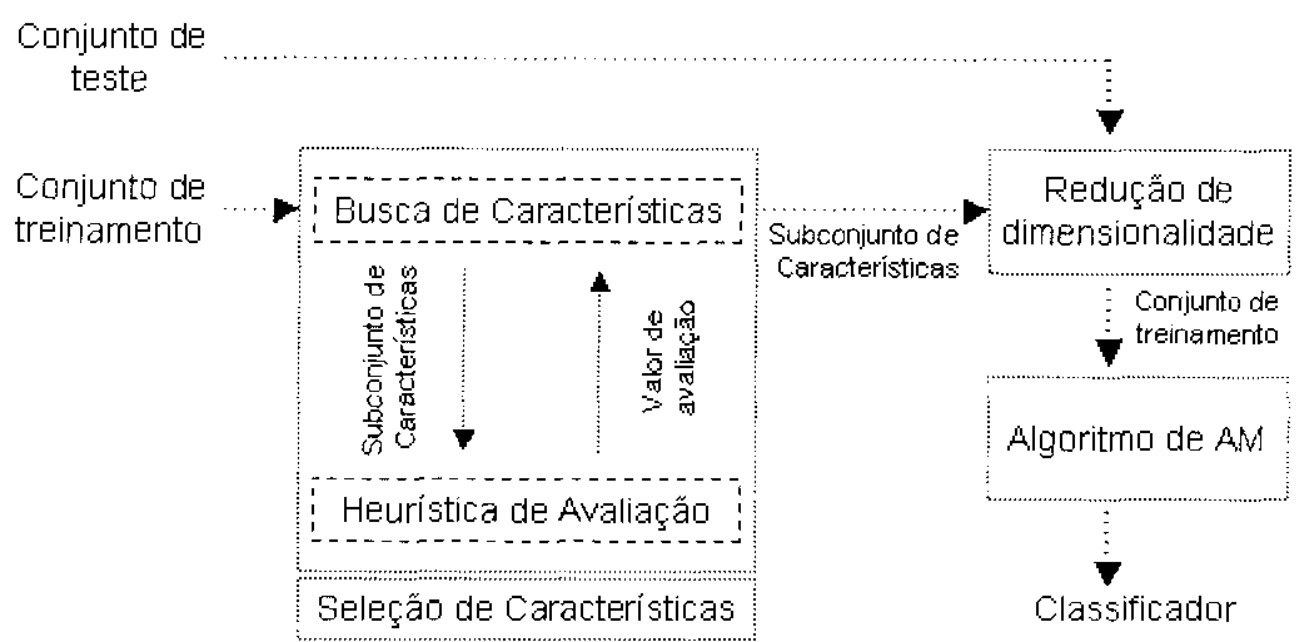

Figura 4.2: Seleção de características baseada em filtros

Algumas vantagens desta abordagen poden ser destacadas:

1. como o processo de seleção não depende de nenhum classificador, ás características selecionadas podem ser itilizadas por diferentes algoritmos de AM:

2. as heurísticas utilizadas para avaliar um subconjunto são computacionalmente pouco custosas, assim os filtros podem ser bastante rápidos e;

3. os filtros conseguem lidar eficientemente com uma grande quantidade de dados.

A principal desvantagem dos filtros refere-se a sua independencia ao algoritmo do AM. Como a SC e o AM são processos separados, o bias ${ }^{3}$ de 1 m não interage com o bias de outro. o que pode levar à construçâo de classificadores com desempenho aquém do desejado.

Quanto às heurísticas utilizadas. os filtros podem ser categorizados de 2 maneiras:

${ }^{3} \mathrm{O}$ bias refere-se à tendéncia dos algoritmos en sistemalicamente favorccer determinarlas situaşôs, dentre as muitas disponiveis. Em AM, um exemplo pode ser a preferència de certos ulgoritmos cm construir classificadores mais on monos complexos. Hn SC, un algoritmo pode preferis caracteristicas que possuan certas propricdades. 
aqueles que avaliam cada característica isoladamente e aqueles que avaliam subconjuntos de: características. Os princiro realizam um ranking das cardcteristicas, segundo algun critério. Por si só, cstes métodos não reduzem a dimensionalidade dos dados. Eles sä́o utilizados em conjunto com algum critério que selecione as características de acordo com o ranking das características. Tipicamente, escolhe-se aquelas que estão mu molhor posição no ranking. A outra maneira considera as características cm interação com ontras. Isto contribui para encontrar subconjuntos bons como $11 \mathrm{~m}$ todo, mas que näo tenham necessarianonte as melhores características individualmente.

As heuríticas que realizam un ranking das características são as mais empregadas na. análise de dados de expressão gênica. Elas podem ser utilizadas para encontrar genes que melhor discriminam cutre estados patológicos. Isso permitiria que os cientistas entendessem melhor a patologria e desenvolvessem novos modicamentos que atuassem diretamente. nas protemas codificadas por tais genes (Guvon e Elisseeff, 2003). Dado sen potencial, os métodos desta abordagem são mais mumerosos. A seguir, os filtros utilizados neste trabalho sào apresentados.

\subsubsection{Golub}

Esste método foi introduzido por Golub ot al. (1999) ). Para realizar o ranking dos genes, de baseia-se on 2 pontos: a expressão hípica de un gene informativo deve ser muito diferente nas classes consideradas (por exemplo, câncer e saudável) e deve existir pouca variação na expressão do gene en uma mesma classe. Para atender a ambos os recatisitos; os antores descnvolveram a métrica $P$. A idéia é que a separação entre as expressóes do $u m$ gene en 2 classesé proporcional à distância entre suas médias. Entretanto. esta distância deve ser normalizada pelos desvios padrões das expressões de cada classse. Assim. a fómula da métrica é a seguinte, dado um vetor c de classes e um vetor $g$ de oxprosisões de um gene en $n$ anostras:

$$
P(g, c)=\frac{\mu_{+}-\mu-}{\sigma_{+}+\sigma_{-}}
$$

onde $\mu_{+} e \sigma_{+}$são a expressão média e o desvio padrão de um gene nas amostras da classe positiva e $\mu_{-} \theta \sigma_{-}$são a cxpressão média e o desvio padrão de um gene nas anostras da chase negativa.

A métrica $P$ assume grandes valores positivos quando o gene ć muito corrolacionado con a classe positiva e grandes valores negativos quando cle é muito correlacionado com 
a classe negativa. Para selecionar $n$ genes a partir do ranking realizado com essa métrica, procede-se selecionando os $n / 2$ primeiros gencs e os $n / 2$ últimos genes.

\subsubsection{Threshold Number of Misclassification - TNoM}

Este método foi introduzido por Ben-Dor et al. (2000a). O 'TNoM bascia-se na idéia de que genes informativos têm valores de expressào muito diferentes nas classes consideradas e, portanto, é possivel encontrar para cada um deles $1 \mathrm{~m}$ threshold que separe as amostras de classes distintas. Este threshold corresponde a uma regra de classificação sinal $(a x+b)$ que minimize o número de erros de classificação. O erro $\operatorname{Err}(a, b \mid g)$ de um gene $g$ é definido por (Ben-Dor et al., 2000b):

$$
\operatorname{Err}(a, b \mid g)=\sum_{i=1}^{n} 1\left\{l_{i} \neq \sin a l\left(a \cdot x_{i}[g]+b\right)\right\}
$$

onde $n$ é a quantidade de exemplos do conjunto de treinamento, $l_{i} \dot{c}$ a classe do $i$-́́simo exemplo e $x_{i}[g]$ é o valor da expressão do gene g no $i$-ésimo exemplo.

O valor de 'l'NoM de um gene gé o número de orros obtido pela melhor regra de classificaça encontrada para aquele gone. A melhor regra é cncontrada otimizando-se os parâmetros a e b na Equaçäo 4.2. Assim. genes com menores valores no ranking possuem maior capacidade de discriminação entre as classes e devem ser selecionados. O cálculo do TXoM é dado pela seguinte equação:

$$
T N O M(g)=\min _{a, b} \operatorname{Err}(a, b \mid g)
$$

\subsubsection{Info}

Este método foi descrito por Ben-Dor et al. (2000a) e Ben-Dor et al. (2002). Fle utiliza. a noçào de entropia proveniente da Teoria da Informaçäo (Cover e Thomas, 1991) para dedernimar quão informativo é um gene para a discriminação de amostras de 2 classes. A seguir, é detalhado como a entropia pode ser utilizada para indicar se um gene é difurentemente expresso em amostras de classes distintas.

Considere um gene $g$ e um vetor $v$, de tamanho $n$, formado de elementos $\{-,+\}$, onde n representa o número de exemplos do conjunto de treinamento. Os elementos deste vetor são dispostos de acordo com as classes dos exemplos ordenados em ordem crescente pelo 
nível de expressão de $g$. Para exemplificar, suponha un conjunto com 10 exemplos. Os níveis de expressão do gene $g$ nos exemplos positivos a negativos são, respectivamente, $\{10,20,30,50,60,70\} \circ\{40,80.90,100\}$. Então,

$$
v=\{+,+,+,-,+,+,+,-,-,-\} \text {. }
$$

O vetor $v$ ó utilizado pra determinar se um gene é expresso diferentemente em amostras de 2 classes. Se o gene é muito ou pouco expresso em amostras de uma classe om comparação com amostras da outra classe uma nítida separação entre elementos positivos e negativos é observada em $v$. Desta forma, é possível particionar $v$ de tal forma que a maioria dos elenientos positivos esteja em um vetor $x$ e a maioria dos clementos esteja em um vetor $y$ (ou vice-versa). No exemplo da Equação 4.4 , $x$ e y poderiam ser:

$$
\begin{aligned}
& x=\{+,+,+,-,+,+.+\} \\
& y=\{-,-,-\}
\end{aligned}
$$

$\Lambda$ partição de $v$ é melhor quanto mais homogêneos forcm $x$ e $y$. Uma medida de homogeneidade pode ser a entropia ${ }^{4}$, definida da seguinte mancira: dada uma variável aleatória $Z$ :

$$
H(Z)=-p \log (p)-(1-p) \log (1-p)
$$

A entropia a utilizada para medir a incerteza associada a uma variável aleatória. Considerando-se o vetor $v$ uma variável aleatória, se $I(v)=0$, entäo todos os clementos de $v$ são iguais e portanto, $v$ ć homogêneo. Quando os números de elementos positivos e negativos são iguais, a entropia de $v$ assume seu valor máximo, $-\log (p)$.

$A$ hesurística INFO associada ao vetor $v$ é definida como a mínima soma ponderada das entropias dos vetores $x$ e $y$, dentre todas as possibilidades de partição de $y$ em vetores $x$ e $y$. A fómula é a seguinte:

$$
\operatorname{Info}(v)=\operatorname{minin}_{x: y=v}\left(\frac{|x|}{|v|} \dot{I}(x)+\frac{|y|}{|v|} \cdot H(y)\right)
$$

onde ! | é o tamanho do vetor.

Para utilizar a entropia deve-se trabalhar con variáveis discretas. Como no domínio de expressão gênica ds características (genes) possuem valores contímos, é necessário a aplicação de técnicas de discretizaçăo. Iiu ct al. (2002) descrevem diversos desses métodos. 
$\operatorname{INFO}(v)=0$ se, e somente se, a partiçăo de $v$ resultar em 2 grupos homogeneos, ou scja, clue al contenha apenas elomentos positivos o $y$ apenas clementos neyativos (ou vice-versa). Assim, quando so utiliza essa heurística para realizar a avaliaçäo os genes, seleciona-se aqueles que estiverem em menores posiçoes do ranking.

\subsubsection{Taxa de Ganho}

Este método é uma versão aprimorada do Ganho de Informação (GI), que é largamente. utilizado na seleção de características Hall (1999). O GI utiliza a medida de entropia de uma variável (classe) antes e depois de observar outra variável (característica) para determinar o guanto o conhecimento de uma pode diminuir a incerteza com relacáo a outra. Formalmente. abs Equaçocs 1.8 o 1.9 säo utilizadas para calcular a entropia do vetor de classes $C$ antes e depois de observar a característica $A$.

$$
\begin{gathered}
H(C)=-\sum_{c \in C} p(c) \log (p(c)) \\
H(C \mid A)=-\sum_{a \in A} p(a) \sum_{c \in C} p(c \mid a) \log (p(c \mid a))
\end{gathered}
$$

onde $p(c)$ é a proporção de exemplos do conjunto de treinamento que pertencem à classe co $p(c \mid a)$ ó a proporção de excmplos cuja característica $A$ assume o valor a que sĩo da classe $c$.

A quantidade pola qual a entropia de $C$ decresce reficte a informação adicional de $C$ fornccida pela característica $A$ e é chamada de ganho de informação, expresso por:

$$
G I(C, A)=I I(C)-H(C \mid A)
$$

As características que obtêm maiores valores de $G I(C, A)$ fornecern mais informaçăn sobre as classes o, portanto, devem ser selecionadas. Entretanto, o $G I(C, A)$ tende a favorecer características que podem assumir maior número de valores. Para evitar este. problema, o $G l(C, A)$ deve ser normalizado pela entropia da característica, resultando na 'Taxa de Ganho (TC):

$$
T G(C, A)=\frac{G I(C, A)}{I I(A)}
$$

Os valores de $T G(C, A)$ están no intervalo de 0 a 1 . Se a caracteristica $A$ e o vetor de classes $C^{r}$ form totalmente independentes, então $T G(C, A)=0$. Caso $A$ e $C$ sejam 
completamente correlacionados, entào $T G(C, A)=1$. Assim, características com maiores valores de $T G$ são preferíveis.

\subsubsection{Wilcoxon}

Este método foi introdurido por Wilcoxon (1945). Para decerminar se um gene é diferentemente expresso en 2 classes distintas, cle testa so os níveis de expressão desse geno seguem a mesma distribuiçâo de probabilidade em todas as amostras ou se, em cada class': eles possuem uma distribuição diferente. Caso as distribuições sejam diferentes, o gene ó considerado informativo para a distinção entre as classes. A seguir, o cálculo do mótodo para um gene é detalhado.

Inicialmente, ordena-se de forma crescente os níveis de expressão do gene cm todas as amostras. Fm seguida, calcula-se a ordem de cada valor, tal que o menor valor receba ordem 1, o segundo receba ordem 2 e succssivamente. Caso haja 2 valores identicos, ambos recebem a média da ordem dos valores. Posteriormente, soma-se as ordens associadas às amostras da menor classe e obtem-se a henrística Wilcoxon $W$. Por fim, calcula-se o $p$ - value associado a $W$.

Para ilustrar o processo, considere um conjunto com 10 elementos, cada um representando o nível de expressão do gene $g$. Os níveis de $g$ nas amostras das classe positiva e negativa são, respectivamente, $\{134,146,104,118,124,161\}$ e $\{70,118,101,85\}$. Ordenando-se todos os valores, teni-se o conjunto $\{70,85,101,104,118,118,124,134,146,161\}$. As ordens deste conjunto são: $\{1,2,3,4,5.5,5.5,6,7,8,9\}$. Somando-se as ordens das amostras cla menor classe (a negativa), tem-se o valor cla heurística $W=1+2+3+5.5 \ldots 11.5$

Para calcular o p-valor associado a $W$, a hipótese nula é que os níveis de expressão de $g$ seguem a mesma distribuicão de probabilidade para todas as amostras. independente de suas classes. Caso isso seja verdade, a heurística $W$ deve estar próxima do valor esperado:

$$
\frac{n_{-}\left(n_{-}+n_{+}+1\right)}{2}=22
$$

onde $n_{-}$c a quantidade de amostras na classe negativa e $n_{+}$é a quantidade de amostras na classe positiva.

Se o valor calculado de $W$ for muito diferente do valor esperado, chtano o $p-v a l o r$ será pequeno, sugerindo que a hipótese nula possa estar errada. Neste caso, os níveis de expressão do gene $g$ poderiam seguir distribuiçóes diferentes, de acordo com a classe 
das anostras. Assim, os genes com os menores $p$-valores possuem maior probabilidade de serem informativos para a classificaçäo das anost as e podem ser considerados cono (andidatos para a scleção.

\subsubsection{ReliefF}

Este método foj introduzido por Kononenko (1994) e é lmana extensäo do algoritmo Rolief original( Kira e Rendell, 1992). Além de ser nuais robusto a dados com ruído, ele pode lidar com problemas multiclasse. O princípio de ambos ć estimar a qualidade das características com base em como seus valores conseguem distinguir entre amostras que estäo proximas umas das outras. A seguir, a forma com o ReliefF realiza essa estimação é detalhada.

Inicialmente, o método scleciona aleatoriamente una amostra $R_{i}$ do conjunto de troillamento o busca seus $k$ vizinhos mais próximos da mesina classe e seus $k$ vizinlos mais próximos de classes distintas. Os primeiros são chamados de acertos $U_{j}$ e os lúltimos são chamados de faltas $M_{j}(C)$, onde $C$ é uma classe. Em seguida, de atualizal as estimativats de qualidade, $W[A]$ : para o conjunto $A$ com a características, considerando os valores de $R_{i}, H_{j} \odot M_{j}(C)$. $\Lambda$ idéia básica é que se as anostras $R_{i}$ e $H_{j}$ tiverem valores muito diferentes para uma característica $\Lambda_{i}$, então esta característica contribui para separar amostras da mesma classe, o que não é desejável. Assim, $W\left[A_{i}\right]$ deve ser decrementada. Por outro lado. se $R_{i}$ e $M_{j}(C)$ tiverem valores diferentes para a característica $A_{i}$, entào A contribui para separar amost ras de classes diferentes o, portanto, a estimativa de qualidade $W\left(A_{i}\right)$ deve ser inerementada. Esse processo a repetido $m$ veges, ondo $m$ ć um valor pré-estabelecido. () pseudo-código do Relieff é dado na Figura 4.3:

Na Figura 4.3 , a função classe $\left(R_{i}\right)$ retorna a classe da amostra $R_{i}$. $\Lambda$ funçäo dif $\left(A_{i}, J_{1}, I_{2}\right)$ calcula a diferença entre os valores das características $I_{1}$ e $I_{2}$. Fla é definida como:

$$
\operatorname{dif}\left(A_{i}, I_{1}, I_{2}\right)=\frac{\left|\operatorname{valor}\left(A_{i}, I_{1}\right)-\operatorname{valor}\left(A_{i} \cdot I_{2}\right)\right|}{\max \left(A_{i}\right) \cdots \min \left(A_{1}\right)}
$$

onde valor $\left(A_{i}, I_{1}\right)$ é o valor que a característica $A_{i}$ assume na amostra $I_{1}$, max $\left(A_{i}\right)$ e $\min \left(A_{i}\right)$ são os maior e menor valores que $A$ assume nas amostras do conjunto de treinamento, respectivamente.

Após a exeougio do Roliceff, tem-se a medida de qualidade calculada para todas as caracteristicas. Aquclas que possuem os maiores $W^{\prime}$ sado mais informativas pala distinguil anostras de classes distintas e, portanto, devem ser selecionadas. 


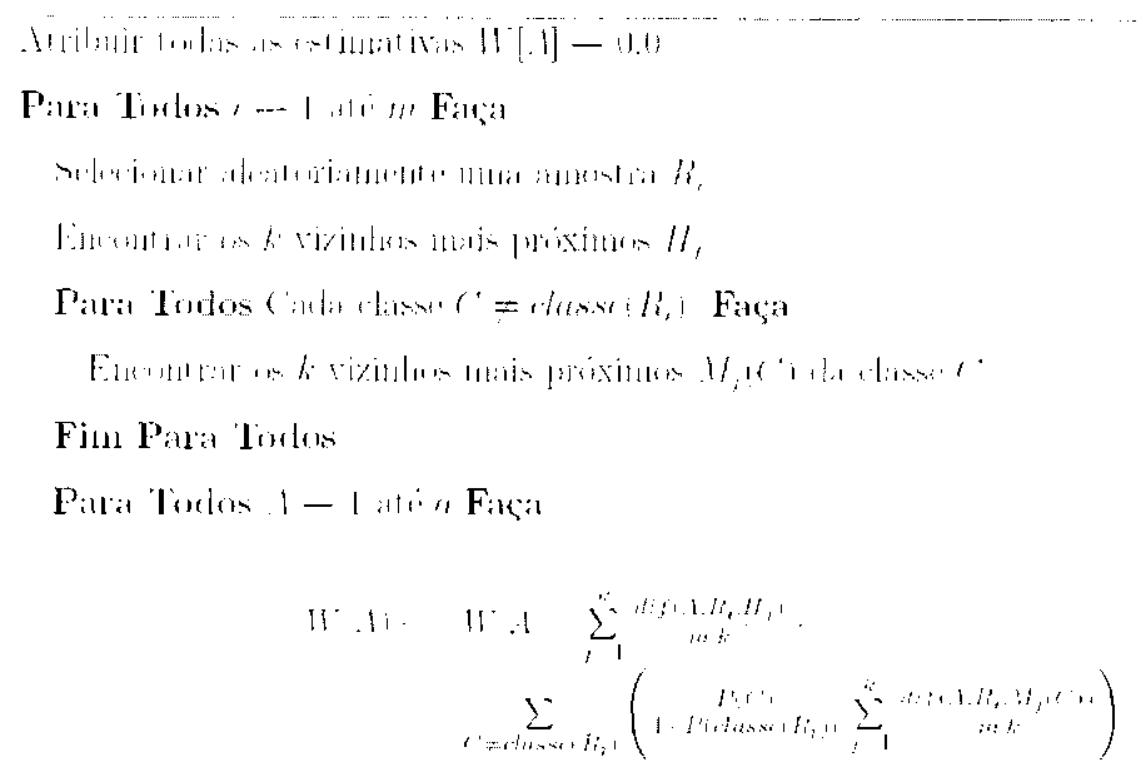

Fin Para linlus

Fin Para Lirdos

Figura 4.3: P'sendo-código do ReliefF.

\subsubsection{Correlation-Based Feature Selection-CFS}

Este método foi introduzido por Hall (1999). Ele avalial subconjuntos de características como um todo, diferentemente das abordagens anteriores, que consideram individualmente cada característica. $\Lambda$ idéia básica do CFS é que bons subconjuntos possuem características altamente correlacionadas com as classes e não-correlacionadas entre si. Assim, tanto características irrelevantes quanto redundantes podem ser desprezadas. Matematicamente, cada subconjunto $S$ b avaliado de acordo com a heurística $M$ erito(S):

$$
\operatorname{Merito}(S)=\frac{k \overline{r_{c f}}}{\sqrt{k}+k(K+1) \overline{\overline{f_{f f}}}}
$$

onde $k$ é o número de características. $\overline{r_{e f}}$ é a correlação média ontre as característicans a as classes e $\overline{r_{f f}}$ é a correlação média das características ontre si. O numerador da Equagàn 4.14 indica o quanto o conjunto de características ó correlacionado com as classess. () denominador indica quanta redundância há no conjunto. Assim, subconjuntos com maiores valores de mérito são preferíveis.

Para calcular $\overline{r_{c f}}$ o $\overline{r_{f f}}$, o CFS utiliza a incerteza simétrica $(I S)$, definida por:

$$
I S\left(X_{1}, X_{2}\right)=2.0 \frac{I G\left(X_{1}, X_{2}\right)}{I I\left(X_{1}\right)+I I\left(X_{2}\right)}
$$




\begin{tabular}{|c|c|c|c|c|c|}
\hline Exemplos & Caract. 1 & Caract. 2 & Caract. 3 & Caract. 4 & Classe \\
\hline$\vdots$ & & & & & $\vdots$ \\
\hline$E_{i}$ & 0 & 1 & 2 & 4 & $C_{1}$ \\
\hline$\vdots$ & & & & & $\vdots$ \\
\hline$E_{j}$ & 0 & 1 & 3 & 4 & $C_{2}$ \\
\hline
\end{tabular}

Tabela 4.1: 2 exemplos de uma base de dados representados por 4 (aracteristicas.

onde $I G\left(X_{1}, X_{2}\right)$ co o ganho de informação entre duas variáveis, como definido na Subseção 1.4.4, e $H(X)$ ó a entropia de $X$. A IS assume valores de 0 a 1 , indicando o nível de: associação entre as variáveis. Maiores valores indican maiores níveis de associação.

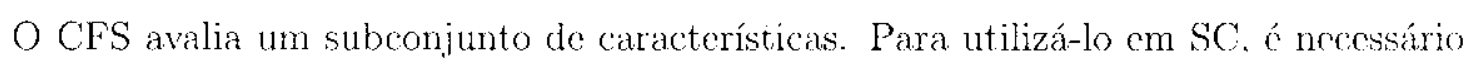
embutíl-lo em um mecanismo de busca que explore o espaço de subconjuntos possíveis. Como uma busca exaustiva não é factivel em domínios com muitas características, como o de dados de expressão gênica, deve-so empregar uma heurística para selecionar o subconjunto, observando-se os pontos da Seção 4.3. Neste trabalho, utiliza-se a geração adiante, ou seja, a partir do conjunto vazio, vai-se acrescentando uma característica de cada vez. Isso é feito de acordo com a seleção sequencial adiante. O processo termina quando a adição de um característica resultar em diminuição do valor de CFS.

\subsubsection{Filtro de Consistência}

Este mótodo é baseado no trabalho de tiu e Setiono (1996) e está exposto em (Hall o Holnes, 2003). A idéia básica é reduzir a dimensionalidade de um conjunto de dados de tal forma que ele permaneça consistente, on seja, que exemplos de classes distintas sejam representados por diferentes combinações de valores das características do subconjunto considerado. Para exemplificar o conceito de consistência, considere a Tabela 4.1, fune mostra 2 exemplos de um conjunto de dados representados por 4 características.

Os cxenplos $E_{i}^{\prime}$ e $E_{j}$ são de classes diferentes o as características utilizadas para representátlos sâo suficientes para fazer essa distinção. Diz-se, cntão, que os exemplos são consistentes. Se os excmplos forem representados apenas pelas característica 1.2 e 1, então excmplos de classes distintas terão todas as características com o mesmo valor, fazendo com que o conjunto de dados fique inconsistente. Assim, este subconjunto de 3 
características näo é desejado.

Para avaliar a consistencia de um subconjunto $S$, utiliza-se a seguinte métrica:

$$
\text { Consistencia }(S)=1-\frac{\sum_{i=0}^{J}\left|D_{i}\right|-\left|M_{i}\right|}{N}
$$

onde J é o número de combinações dos valores de características de $S,\left|D_{i}\right|$ ć o número de ocorrências da i-ésima combinação, $\left|M_{i}\right|$ é a quantidade de exemplos da maior classe o $N$ é a quantidade de exemplos do conjunto de dados.

Para encontrar subconjuntos de características de consistência elevada, será utilizado a geraģa adiante e a seleção sequencial adiante, como apresentado na Subseção 4.3.1. () processo temina quando a adição do um caracteristica resultar em diminuição do valor do consistência. Esta metodologia é análoga à utilizada por Hall e Holmes (2003). Ressalta-se ainda que, assim como nos métodos bascados em cntropia, para calcular-se a consistência de um subconjunto de caractorísticas, é necessário aplicar técnicas de discretização, caso os valores sejam contínuos.

\subsection{Wrappers}

Ao contrário da abordagem de filtros vista na seção anterior, na seleçäo de características utilizando wrappers (John et al., 1994), os algoritmos de classificação desempenham papel fundamental na redujão de dimensionalidade dos dados. Eles são utilizados para avaliar os subconjuntos de características e decidir por aquele que maximize o desempenho do classificador em um determinado domínio (Kohavi e John, 1997). A principal motivação para o uso de wrappers é precisamente a interação entre os bias das técnicas de SC e dos algoritmos de $\Lambda \mathrm{M}$, que podem proporcionar a seleção de subconjuntos ótimos, do ponto de vista de alguma estimativa de classificaçäo.

Genericamente, esta abordagem é representada pela Figura 4.4. Há 3 pontos básicos a serem observados: a estratégia de busca empregada, a forma como o rassificador ́́ utilizado para avaliar as características e a escolha do algoritmo de AM. A busca por subconjuntos de caracteristicas geralmente é feita de acordo com os aspectos observados na. Seção 4.3. Para avaliar as características, o desemperho dos classificadores pode ser estimado por meio de un conjunto de dados de validação. É possível também fazcr a avaliação com uso de propricelades intrúnsecas ao algoritmo de AM, como será visto nas 
subseçóes seguintes. Por firm, ó necessário definir o algoritmo utilizado. Neste trabalho, serào consideradas exclusivanonte as SVMs.

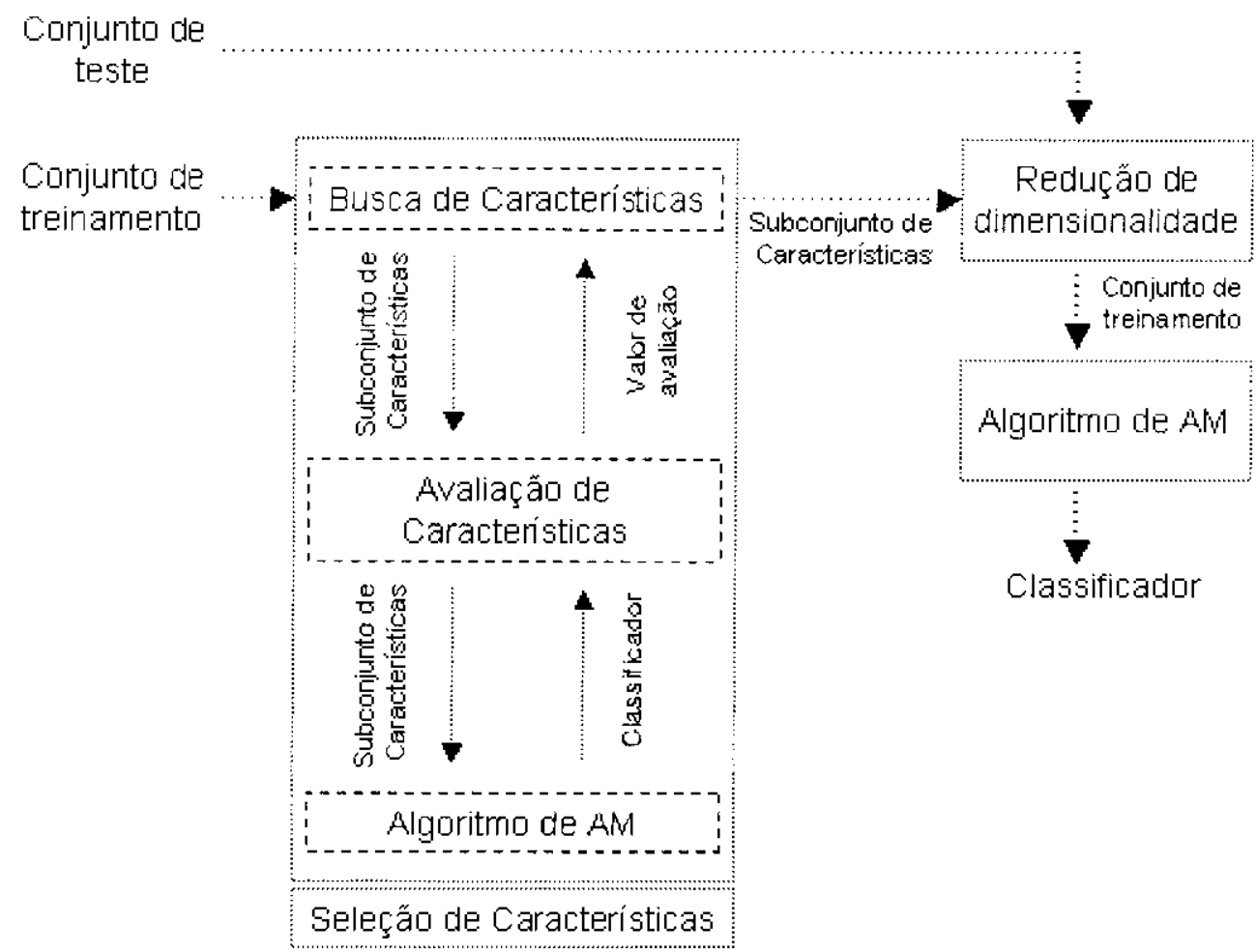

Figura 4.4: Seleção de caracteristicas bascarla em urappers.

Os uruppers apresentam 3 desventagens em relaçào às abordagens do tipo filtro:

1. como o algoritmo de AM ó utilizado para avaliar os subconjuntos de características, cle deve ser executado diversas vezes, ocasionado um custo computacional elevado, mesmo para bases de dados de dimensão moderada;

2. quando as bases de dados possuem poucos exemplos, como no caso de dados de expressão gênica, a melhor forma de medir o desempenho do classificadores ce ainda um assunto cm aberto. As técnicas de validação cruzada, por exemplo, tem-se mostrado inadequadas nesta situação (Kohavi e Sommerficld, 1995) e;

3. como os wrappers são projetados considerando-se um algoritmo de AM espeć́fico, é necessário repetir o processo de SC sempre que outro algoritmo for utilizado.

$\Lambda$ seguir, os wrappers para SVM tratados neste trabalho serão apresentados. Apesale de vários estudos recentes terem apresentado novas técnicas de SC no contexto de SVMs, o enfoque será dado a 2 deles, devido principalmente aos bons resultados relatados no domínio de oxpressão gênica e à disponibilidade de software para a realizaça de 
experimentos.

\subsubsection{Recursive Feature Elinination - RFE}

Este método foi proposto por Guyon el al. (2002). Ele basein-se na idéia de que as caractcrísticas menos relevantes para a classificação possuem pouca influência no hiperplano ótimo defunido pelo algoritmo das SVMs ${ }^{5}$ e podem, portanto, ser desconsideradas. Formalmente, o objetivo do RFE é encontrar um subconjunto de $r$ caractcrísticas, de um total de $d(r<<d)$, tal que o desempenho do classificador seja maximizado. lsto é feito utilizando a seleção sequencial para trás, a partir do conjunto completo de características.

Cada característica ć avaliada de acordo com sua influência na margen da SVM. O valor da margem é inversànente proporcional a $W^{2}(\alpha)$, que é função dos multiplicadores de Lagrange $x_{i}$ obtidos pelo algoritmo de treinamento da SVM. O valor de $W^{2}(\alpha)$ é definido pela Fquaçăo 4.17 (Rakotomamonjy, 2003):

$$
W^{2}(\alpha)=\sum_{i=1}^{N} \sum_{j=1}^{N} \alpha_{i} \alpha_{j} y_{i} y_{j} K\left(\overrightarrow{x_{i}}, \overrightarrow{x_{j}}\right)
$$

onde $N$ é a quanticlade de exemplos de troinamento, $y_{i}$ á a classe do i-ésimo exemplo e $h(\cdot, \cdot)$ é a função de kernel. O critério de relevância $J$ : para cada característica $p$, corresponde a quanto cla contribui para o valor de $\vec{W}(\alpha)$ e é definido por:

$$
J(p)=\left|\vec{W}(\alpha)-\vec{W}_{-p}(\alpha)\right|
$$

onde $\vec{W}_{-p}(\alpha)$ indica o cálculo de $\vec{W}(\alpha)$ sem a característica $p$. Nas SVMs lineares consideradas neste trabalho, $J(p)$ corresponde a $w_{p}^{2}$, ou seja, a p-ésima componente do vetor normal ao hiperplano separador ótimo (vide Equação 3.5, do Capítulo 3).

Comegando a partir do conjunto completo de características, a SVM é treinada e a característica com o menor valor do $J(p)$ é removida. A SVM é treinada novamente e $W^{2}(\alpha)$ é calculado outra vez. A característica com o menor valor de $J(p)$ é removida unsta nova iteraço e o processo repete-se até que o número desejado $r$ de características scja obtido.

${ }^{5}$ Parra informaçóes sobre SVMs, vide o Capítulo 3 


\subsubsection{Approximation of the zero-norm Minimization - AROM}

Este método foi proposto por Weston et al. (2003b). Ele utiliza a noşão de norma-0 do vetor $\vec{u}$. normal ao hiperplano separador de classificadores lineares, como SVMs, para selecionar conjuntos de características. A idéia ć limitar o número de componentes w não-nulos e diminuir a norma-p de $\vec{w}$, mantendo o erro de treinamento pequeno. Desta forma. o número de características utilizadas e o erro de generalização do classificador podem ser mininizados simultancamente. Formalmente, o método e representado pelo segunte problema:

$$
\begin{cases}\text { Minimizar: } & \| \vec{w} !_{p} \\ \text { Sujcito a: } & y_{i}\left(\left\langle\vec{w} \cdot \overrightarrow{x_{i}}+b\right)-1 \geq 0, \quad i=1, \ldots, N\right. \\ & \mid \vec{w} \|_{0} \leq r\end{cases}
$$

onde $p=\{1,2\}$ é o tipo de noma, $y_{i}$ é a classe do exemplo $\overrightarrow{x_{i}}, b$ é o termo de bias, $N$ é o mímero de exemplos do conjunto de treinamento, a norma-0 $\left|\overrightarrow{x_{i}}\right|_{0}$ é a quantidade de demento não-nulos de $\overrightarrow{x_{i}}$ e $r$ é o número desejado de características. F́ interessante notar que este problena é semelhante (exceto pela restrição da norma-0) ao da Ec. 3.11, que corresponde ao problema de SVMs para dados linearmente separáveis

A Eq. 4.19 pode ser aproximadamente resolvida utilizando o seguinte processo baseado em SVMs:

1. Treinar uma SVM linear.

2. Re-escalar as características multiplicando-as pelos valores absolutos dos componentes de $\overrightarrow{\text { ut }}$ obtido no passo anterior.

3. Retornar ao passo 1 até que o número $r$ de características tenha sido alcancado.

Este processo é chamado de Aproximação de Minimização de Noma Zero (AROM do inglês Approximation of the zero-norm Minimization), pois o número de componentes $w_{i}$ de $\mid \overrightarrow{u_{i}}$ não-nulos é minimizado. Intuitivamente, o AROM altera a influência das características gradativamente, re-escalando-as em cada iteração. Assim, as características que não são nocessúrias para classificar corretamente os exemplos pela SVAI tendern rapidamente a assumir valores muito próximos a zero. Por outro lado, as caractcrísticas 
relevantes tencien a ganhar mais importancia. Ao final do processo. apenas $r$ características teräo valores diferente de zero e, então. 1uma SVM poderá ser treinada com este subconjunto

\subsection{Algoritmos Genéticos para Seleção de Genes}

Algoritmos Genéticos (AGs) são técnicas de busca e otimização inspiradas no proccsso de evolução dos seres vivos (Goldberg, 1989). Um AG simples utiliza uma população de individuos para resolver um dado problema. Cada indivíduo, ou cromossono, correspondo a una possível solução codificada do problema. Mecanismos baseados em reprodução e en mutação são aplicados à população atual para gerar uma nova. As populaçóes vão evoluindo por diversas geraşões até que um dado critério de parada seja atendido.

() algoritmo começa com uma população de indivíduos gerados aleatoriamente, que podem ser vistos como tentativas iniciais de soluções para o problema. A população é avaliada e. para cada cromossomo. uma pontuação. chamada de aptidão. é dada, refletindo a qualidade da soluçâo associada e ele. Os indivíduos mais aptos têm maiores chances de sobreviver e, assim, seren transmitidos para a geraçăo seguinte. O processo do AG ó ilustrado na Figura 4.5:

Os AGs têm sido largamente conpregados na SC (ver (Yang e Honavar, 1998) e referências ali contidas). A principal razão de sua utilização é a capacidade de realizar buscas eficientemente em um grande espaço de possibilidades, como no problema da seleção de genes em dados de expressão gênica. De fato, neste domínio, alguns trabalhos relatam resultados promissores Ooi e Tan (2003) Li o ct al (2001). Neste trabalho, 2 novas abordagens são propostas. A primeira é um filtro que busca por subconjuntos de genes tal que o domínio seja melhor representado, de acordo com critérios de qualidade. A segunda un wrapper para SVMs que emprega alguns resultados teóricos de SVMs para avaliar os subconjuntos de genes. do ponto de vista da classificação.

As 2 abordagens diferem apenas no cálculo da função de aptidão dos cromossomos. Assim, estas serão descritas em subsccões diferentes. Os demais aspectos do AG são discutidos a seguir:

1. Representação. Os cromossomos são geralmente codificados na representação binária. Cada subconjunto de genes pode ser representada por cromossomo de tiama- 


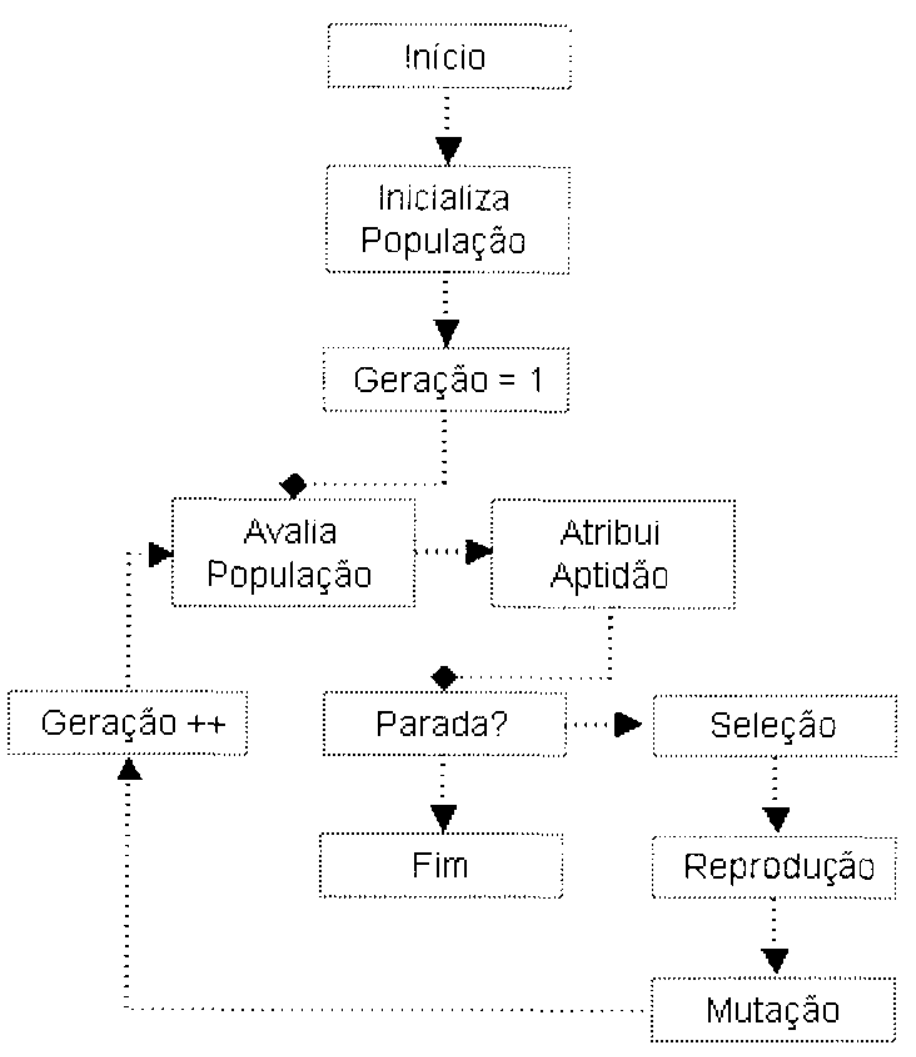

Figura 4.5: Flıxograma do um AG simples. Adaptado de (Dob e Kalyanmoy, 2001)

nho $m$, onde $m$ é o número total de genes do domínio. 1 ou 0 na i-ésima posição do cromossomo indica a presença ou ausência do i-ćsimo gene no subconjunto.

2. Inicialização. Neste trabalho, todos os cromossomos são inicializados aleatoriamente com poucas posições com o valor 1. A razão disso é que acredita-se que apenas alguns genes são necessários para a classificação do probleña em estudo.

3. Mutação. A mutação é o operador genético responsável por manter a diversidade da população. Ela opera invertendo aleatoriamente algumas posições do cromossomo, de acordo com uma probabilidade. Lm valor de probabilidade commmente utilizado é $1 / m$, onde $m$ é o tamanho do cromossomo.

4. Reproduçāo. () operador que realiza a reprodução é chamado de cruzamento. Ele é utilizado para guiar o processo evolucionário por soluçoes potencialmente melhores. Ele funciona através da troca do material genético de 2 indivíduos (denominakos de pais) para a geração de novos indivíduos (denominados do filhos), tal que estes herdem propriedades daqueles. Este processo é inspirado na reprodução sexuada dos animais. Neste trabalho, utilizou-sc o cruzamento SSOCF (do inglês Subset 
Size-Oriented Common Feature Crossover Operator) (Emmanouilidis et al., 2000). Ele foi desenvolvido especificamente para o problema de SC e possui a vantagem de. preservar porçós informativas do material genético dos pais e produzir indivíduos que tenham aproximadamente a mesma distribuição daqueles.

5. Substituiçāo. Os esquemas de substituição determinam como as novas populações são geradas. Neste trabalho, utiliza-se o conceito de populaçóes sobrepostas (overlapping populations), scgundo o qual os individuos novos e antigos juntam-se em uma população temporária e os melhores formaram a população da próxima geração.

6. Seleção. É o processo de escolher os indivíduos que irẫo reproduzir. Geralmente, ela prioriza as melhores soluçóes da população. Neste trabalho, como o esquema de substituiçäo já prover pressão seletiva suficientemente alta, optou-se por utilizar a selecão randômica de indivíduos. (Whitley, 1994)

7. Migração Randômica. É um método que ajuda a manter a diversidade da população, minimizando o risco de convergência prematura do algoritmo (Congdon, 1995). Ela funciona substituindo os indivíduos cujas aptidões estão abaixo da média da população atual por novos indivíduos aleatoriamente gerados. A migraçào randônica é invocada quando o melhor indivíduo não muda por un certo número de geraçoes (chamado aqui de frequência de re-início).

\subsubsection{Filtro}

O filtro desenvolvido é chamado AG-Filtro (versão preliminar publicada cm (de sonza c de Carvalho, 2004b)). Ele utiliza apenas as características intrínsecas do conjunto de trcinamento para selecionar os subconjuntos de genes. Como resultado, ele não é limitado a nenhum algoritmo de classificação específico e é eficiente. Para avaliar os subconjuntos, 2 medidas de qualidade são empregadas: um índice de validação e uma medida de impureza. A idéia é utilizar o AG para procurar por genes que nnelhor representem o domínio. Entăo, a complexidade de classificação pode ser minimizada e, ao mesmo tempo. genes importantes para a patologia em estudo podem ser revelados. 


\section{Medidas de qualidade de grupos}

Seja $S=\left\{\left(\overrightarrow{x_{1}}, y_{1}\right), \ldots,\left(\overrightarrow{x_{n}}, y_{n}\right)\right\}$, onde $\overrightarrow{x_{i}} \in X \subset R^{m}$ e $y_{i} \in\{0,1, \ldots, c\}$, um conjunto de treinamento com $n$ exemplos e c classes. Cada $\overrightarrow{x_{i}}$ é um vetor de critrada de dimensão $m$ e cada $y_{i}$ corresponde à classe associada ao exemplo $\overrightarrow{x_{i}}$.

Cada classe é representada por um grupo de exemplos do conjunto de treinamento. Os grupos sào fomalos por oxemplos que possuem características comms com exemplos do mesmo grupo e são bastante diferentes de exemplos de outros grupos. A (dis)similaridade entre os exemplos dos grupos é fortemente influenciada pelo conjunto de genes utilizado para representar o domínio. Por exemplo, os genes $\{a, b, c\}$ podem produzir grupos molhores que os genes $\{d . e, f\}$. Para determinar o quanto um conjunto de genes é melhor que outro, 2 medidas podem ser aplicadas: um índice de validação e uma medida de impuroza.

Índice de validação

Os índices de validaço Jain e Dubes (1988) são utilizados na literatura de algoritmos de particionamento para avaliar as partições geradas. Neste trabalho, o objetivo não é particionar o conjunto de dados e sim avaliar como um dado subconjunto de genes se compara com outro subconjunto, de acordo com alguns critérios. O objetivo é encontrar subconjuntos que resultem em grupos compactos internamente e separados uns dos outros.

Para isso, foi desenvolvido o índice de validação Val_indice:

$$
\text { Val_indice }=\frac{1}{2 n} *\left(\sum_{i=1}^{c} \sum_{r \in C_{i}} D\left(\vec{x}, \overrightarrow{v_{i}}\right)\right)+\frac{1}{2} *\left(1-\min _{i, j=1, i \neq j} D\left(\overrightarrow{v_{i}}, \overrightarrow{v_{j}}\right)\right)
$$

onde $D$ ć a distância entre 2 elementos e $\overrightarrow{v_{i}}$ é o centróide do i-́simo grupo, on seja, o elementos mais representativo do grupo. Os valores deste índice variam de 0 a 1.

Estudos recentes (Kuramochi e Karypis, 2001) (Alon et al., 1999) têm mostrado que medidas de distância baseadas em correlação são mais apropriadas a dados do expressão gênica que a distancia euclidiana convencional, na medida cm que elas focam na forma relativa do padrão genético e não na sua magnitule absoluta. Assim. distâncias bascadas na correlaçấo de Pearson e no coseno entro 2 amostras têm sido empregadas. Neste trabalho, a distância baseada na correlação de Pearson é dada pela Equação 4.21 o a distância baseada no coseno é dada pela Equação 4.22 


$$
D_{\operatorname{Cos}}\left(\vec{x}_{i}, \vec{v}_{j}\right)=1-\left(\cos \left(\vec{x}_{i}, \vec{x}_{j}\right)\right)^{2}
$$

onde cos $\left(\overrightarrow{x_{i}}, \overrightarrow{x_{j}}\right)$ representa o coseno entre os exemplos $\overrightarrow{x_{i}}$ e $\overrightarrow{x_{j}}$.

$$
D_{C o m}\left(\overrightarrow{x_{i}}, \overrightarrow{v_{j}}\right)=1 \cdots\left(\operatorname{abs}\left(\operatorname{corr}\left(\overrightarrow{x_{i}}, \overrightarrow{x_{j}}\right)\right)\right)
$$

oude abs ć a função que retorna o valor absoluto de sen argumento e corr $\left(\overrightarrow{x_{i}}, \overrightarrow{x_{j}}\right)$ representa a correlacão de Pearson entre os exemplos $\overrightarrow{x_{i}}$ e $\overrightarrow{x_{j}}$.

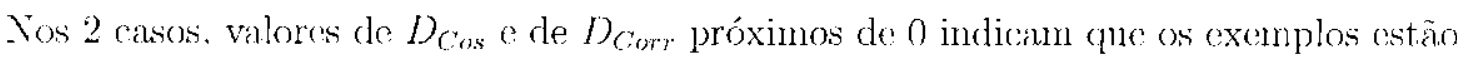
próximos e valores próximos de 1 indicam que os exemplos estão afastados. Para calcular os contróides $v_{j}$, utiliza-se a seguinte Equação:

$$
\overrightarrow{v_{j}}=\frac{1}{\vec{c}_{j}} \underset{x_{i} \in C_{j}}{\sum_{i}}
$$

onde $\left|C_{j}\right|$ é à número de exemplos da classe $j$.

Assim: a Eq. 4.20 mede quão compactos são os grupos intermamente e quão separados ales estão uns dos ontros, de acordo com a distância utilizada. O índice varia de 0 a 1 , onde baixos valores indicam melhores grupos.

\section{Medida de impureza}

() índice Gini tem sido commnente utilizado para medir a impureza de mma dada partição de árvores de decisão (Breiman et al. 1984). Teste trabalho, ele a utilizado para modir quầ ben um subconjunto de genes representa os grupos do conjunto de treinamento. Por exemplo, ele assume valores baixos se os exemplos de uma classe forem mais similares aos exemplos do grupo que representa aquela classe do que aos excmplos de grupos que representam ontras classes. Desta forma, ele pode ser encarado como mm indicativo da qualidade dos grupos.

O indice Gini para um grupo $G_{j}$ é definido como:

$$
\operatorname{Gini}_{j}=1-\sum_{i=1}^{\complement}\left(\frac{\Gamma_{j i}}{n_{j}}\right)^{2}: j=1, \ldots, c
$$

onde $P_{j i}$ co o múmero de exemplos do grupo $j$ classificados como pertencentes a classe $i$ o $n_{j}$ é o número total de exemplos do grupo $j$. A classificação das amostras é bascada em sta proximidade aos centróides dos grupos

A impureza combinada clos grupos é dada pela Fuaçàn 4.25: 


$$
\text { Irrpureza }=\frac{\sum_{j=1}^{c} T_{P_{j}} * \operatorname{Gini}_{j}}{n}
$$

onde $T_{P_{j}}$ ća probabilidade de um exemplos pertencer a grupo $j$ e $n$ é o número total de exemplos do conjunto de treinamento.

\section{Função de aptidão}

Um dos aspectos mais críticos dos AGs é a funçăo de aptidão. Una boa função para o problema da selcção de genes deve focar em subconjuntos que produzam bons grupos de cxemplos no conjumto de treinamento e que sejam compactos. Assim, a qualidade de uma solução é avaliada do acordo com a medida de impureza e o índice de validação apresentados anteriomente. A função de aptidão (que deve ser minimizada) associada a um subconjunto $\lambda$ de genes é expressa por:

$$
\text { Aptidao }(\lambda)=b_{1} * \text { Impureza }(\lambda)+b_{2} * V a l \_ \text {indice }(\lambda)+b_{3} * \operatorname{dim}(\lambda)
$$

onde Impurcza( $\lambda)$ é a medida de impureza definida pela Equação 4.25 com respeito ao subconjunto $\lambda$, Val_indice $(\lambda)$ é o índice de validação definido pela Equação 4.20 com respeito ao subconjunto $\lambda, \operatorname{dim}(\lambda)$ é o de genes selecionados em $\lambda$ c $b_{1}, b_{2}$ e $b_{3}$ são termos de regularização.

Dependendo da distância utilizada para calcular a Equação 4.20, 2 versäo do $\Lambda$ G-Filtro pode ser utilizadas: o AG-Filtro Cos, que utiliza a distância definida na Equaçäo 4.21 e AG-Filtro Corr, que utiliza a distancia definida na Equacio 4.22. Esta nomenclatura será utilizada pelo resto do texto.

\subsubsection{Wrapper}

O wrapper desenvolvido neste trabalho chama-se AG-SVM e uma versão preliminar dele foi publicada cm (de. Souza et al., 2004). O AG-SVM baseia-se em alguns resultados tóricos do SVMs para selecionar subconjuntos de genes que proporcionem um born descmpenho de classificação. Para isso, a função de aptidão do AG deve explorar explicitamente alguma estimativa de desempenho de SVMs utilizando apenas o conjunto de treinamento.

Há várias (lessas estimativas disponíveis, como a razăo raio/margem (Vapnik, 1995), o conceito de span de vetores de suporte (Vapnik e Chapelle, 2000), a dimensão VC (Vapnik, 1995), o estimador $\xi a$ (Joachims, 2000) o o GACV (Wahbd. 1999), entre outros. Fm uma 
comparacão entre todos estes mótodos para fazer a selecão de valores de parâmetros de SVMrs, et al (2002) conslaton que o estimador \&or apresentou bons resultados cm cestinur o desempenlo de SVML. além de ser pouco custoso computarionalmente Assim, escolhen-se o esta cstimativa como base do $\mathrm{AG}-\mathrm{SVM}$.

$O$ estimador $\xi a$ foi concebido como sendo uma aproximação do cro de validação cruzada do tipo LOOCV (esta abordagem é detalhadamente explicada no Capítulo 5) Ele ó dolinido pela Equação 4.27:

$$
\operatorname{Erro}_{\xi \alpha}^{n}=\frac{\left|i \cdot\left(\rho \alpha_{i} R_{\Delta}^{2}\right) \geq 1\right|}{n}
$$

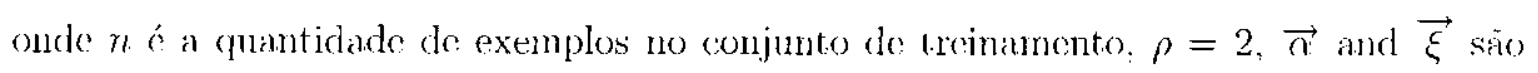
os multiplicadores de Lagrange e a variáveis do folga, respectivamente obtidos com a resolução do Problema 3.20 do Capítulo 3 e $R_{\Delta}^{2}$ e um limito superior de $k(\vec{x} \cdot \vec{x})-$ $k(\vec{x} \cdot \vec{z}), \forall \vec{x} \cdot \vec{z} \cdot \vec{x}$ e $\vec{z}$ são exemplos de treinamento.

Quanto menor o valur de Erro $\xi_{\alpha}^{n}$ melhor o desempenho estimado das SVMIs. Assim, a solução óbvia para o problema de seleção de genes seria procurar por aqueles genes que minimizassen Errogo . Fntretanto, experimentos preliminares mostraran que ussa não é uma boa solucaio. A razào disto é que quando há poncos exemplos de tremancruto e o domínio apresenta una dimensionalidade muito grande, é trivial encontrar subconjuntos de características tal que $E r r o_{\xi 1}^{n}=0$. Entretanto, para exemplos năo vistos durante o trcinamento, o desempenho de classificação pode ser extromamente baixo, caracterizando o overfitting comentado no Capítulo 3. Assim, é necessário utilizar uma abordagem mais roluusta para solecionar subconjuntos de gones.

A estratégia adotada combina o Érro ${ }_{\xi \alpha}^{n}$ e algunars idćias utilizadas pela tócnica RFE vista anteriomente. O RREE sclecionar ats características de acordo con a influencia das mesmas na margem da SVM. Neste trabalho, desenvolven-se un urapper que seleciona subconjuntos tal que Erro $\xi_{k x}^{n}$ scja minimizado o genes tenham grande influencia na margem da SVM. A abordagen é como segue: inicialmeste, uma SVM é treinada com todos os gencs e o hiperplano separados ótimo ó encontrado. O hiporplano é definido por uma vetor $\vec{W}$. A cada gene $i$, ć associado um valor $w_{i}^{2}$ e que corresponde ao quarlrado da i-ćmia componenu do votor $\vec{W}$. Este valor indica a influència do gene i na margem da SVM. Eun seguida os genes sáo dispostos em ordem crescente do acordo com os valores de: $u_{i}^{2}$ o armazenados $\mathrm{cm}$ um vetor $\vec{O}$.

A intenção é selecionar genes com grandes valores de $w_{i}^{2}$. Assim. para cada subeon- 
junto de genes avaliado, considera-se aquele que possuna o valor mediano de $w_{i}^{2}$ naquele subeonjunto ( verifica-so cln que posição de ranking elo se encontra no vetor $\vec{O}$. Depois: divide-se essa posição pela posição míxina en que cle pode se encontrar. que é a quantidado total de' genes e obtém-se um valor nomalizado entre 0 a 1 da influência dacpuele gene na margem da SVM. Valores mais altos indicam maior infuência do gone om relaçäo aos demais. Assim, aumentando o valor de ranking normalizado clo gene mediano, aumenta-se a relevância do subconjunto como um todo.

Função de aptidão

A funçũo de aptidão do AG-SVM para um subconjunto $\lambda$ é definida pela Equação 4.28:

$$
\text { Aptirlao }(\lambda)=b_{1} * \operatorname{Error}_{\xi(\alpha}^{\prime \prime}(\lambda)+b_{2} *\left(1-\operatorname{Rank}_{n} \operatorname{ormal}(\lambda)\right)+b_{3} * \operatorname{dim}(\lambda)
$$

onde $\operatorname{Erro}_{\xi o}^{n}(\lambda)$ a a estimativa definida pela Equaciano 4.27 com respeito ao subconjunto $\lambda$. Rankinomal $(\lambda)$ é o valor do rank normalizado do gene mediano do subconjunto $\lambda$, $\operatorname{dim}(\lambda)$ é o de genes selecionados em $\lambda$ e $b_{1}, b_{2}$ e $b_{33}$ são tormos de regularização.

\subsection{Considerações Finais}

Neste Capitulo os conceitos principais sobre selecão de caracteristicas foram apresenta dos. Inicialmente, um conceito formal para o problema foi introduzido. Fm scguida, umil taxonomia bascada em diversos critérios foi apresentada. As diversas técnicas utilizadas ueste trabalho (tanto filtros como wrappers) foram abordadas. Por fun, os métodos desenvolvidos pelo autor foram apresentadas. 
Capítulo 5

\section{Experimentos}

\subsection{Considerações Iniciais}

Este Capítulo apresenta os experimentos realizados neste trabalho. O objetivo ó realizar um estudo comparativo entre as diversas técnicas de SC apresentadas anteriormente aplicadas ao problema da seleção de genes. Para tanto. são utilziadas bases reais de dados de expressão gênica provenientes de experimentos de microarrays. Os critérios utilizados para avaliar os resultados são o erro da SVM quando treinada com os subconjuntos de genes selecionados pelos algoritmos e a taxa de redução de dimensionalidado do domínio.

o Capítulo está organizado como segue. Inicialmente, a metodologia aplicada na condução dos experimentos é detaltada. Posteriomente, os conjuntos de dados utilizados são descritos. Fn seguida os resultados são apresentados para todas as bases de dados e algumas consideragoes são feitas. Por fim, as conclusões do Capítulo são apresentadas.

\subsection{Metodologia}

\subsubsection{Descrição Geral}

A metodologia descrita a seguir é baseada no trabalho de Ambroise e McLachlan (2002). Os autores estudaram a forma ató então comumente empregada para avaliar métodos de seleção de genes em dados de microartay e observaram uma deficiência que pode lovar a conclusões erròneas acerca do desempenho dos algoritmos: o bias de seleção. Ele ocorre quando os métodos de SC são aplicados sobre todo o conjunto de dados. que depois ć particionado cm conjuntos de treinamento e teste e a avaliação do desempenho do classificador treinado com o subconjunto sclecionado é realizada. Como a seleção foi feita anteriomente à partiça dos dados, o conjunto de teste foi utilizado indevidamente e, consequentemente, a taxa de erro de classificagào tende a ser menor que a verdacieira. 
Para corrigir o problema, os antores do trabalho sugerem que os métodos de SC sejam embutidos en un esquema de validaçä́o muzada. A validação cruzada de fator $k$ (do inglês $k$-fold cross validation) é utilizada comumente para estimar o desempenho de algoritmos de AM e fazer comparações de desempenho entre cles (Duda et al., 2000). Quando $k$ for igual à quantidade de exemplos no conjunto do dałos, a validação cruzada é chamada de LOOCV (do inglês leave-one-out cross validation) (Duda et al., 2000). O esquema consiste on dividir aleatoriamente os coujuntos de dados cm $k$ partições mutuamente exchusivas de exemplos e de tamanho aproximadamente igual. No procedimento implementado, a mesma proporçầ de classes do conjunto de dados completo é mantida cm cnda partiçäo. Das k partiçós, $k-1$ são utilizadas para o treinamento do algoritmo dc $\Lambda \mathrm{M}$ e a restante é utilizada para teste. O processo é repetido $k$ vezes, en cada uma trocando a particão ntilizada no teste. O percentual de exemplos classificados incorrotamente em cada partição de teste é somado e dividido por k e obtém-se uma estiunativa da taxa de erro do classificador.

No contexto da SC, as técnicas devem ser aplicados em cada partiçâo da validação cruzada e, cm seguida, o classificador treinado utilizando os dados com a dimensão reduzida é utilizado para avaliar os cxemplos de teste. Embora os genes solecionados cm cada particano possam ser diferentes. o desempenho dos métodos pode ser estimado de uma maneira honesta. A Figura 5.1 ilustra a metodologia completa utilizada neste trabalho.

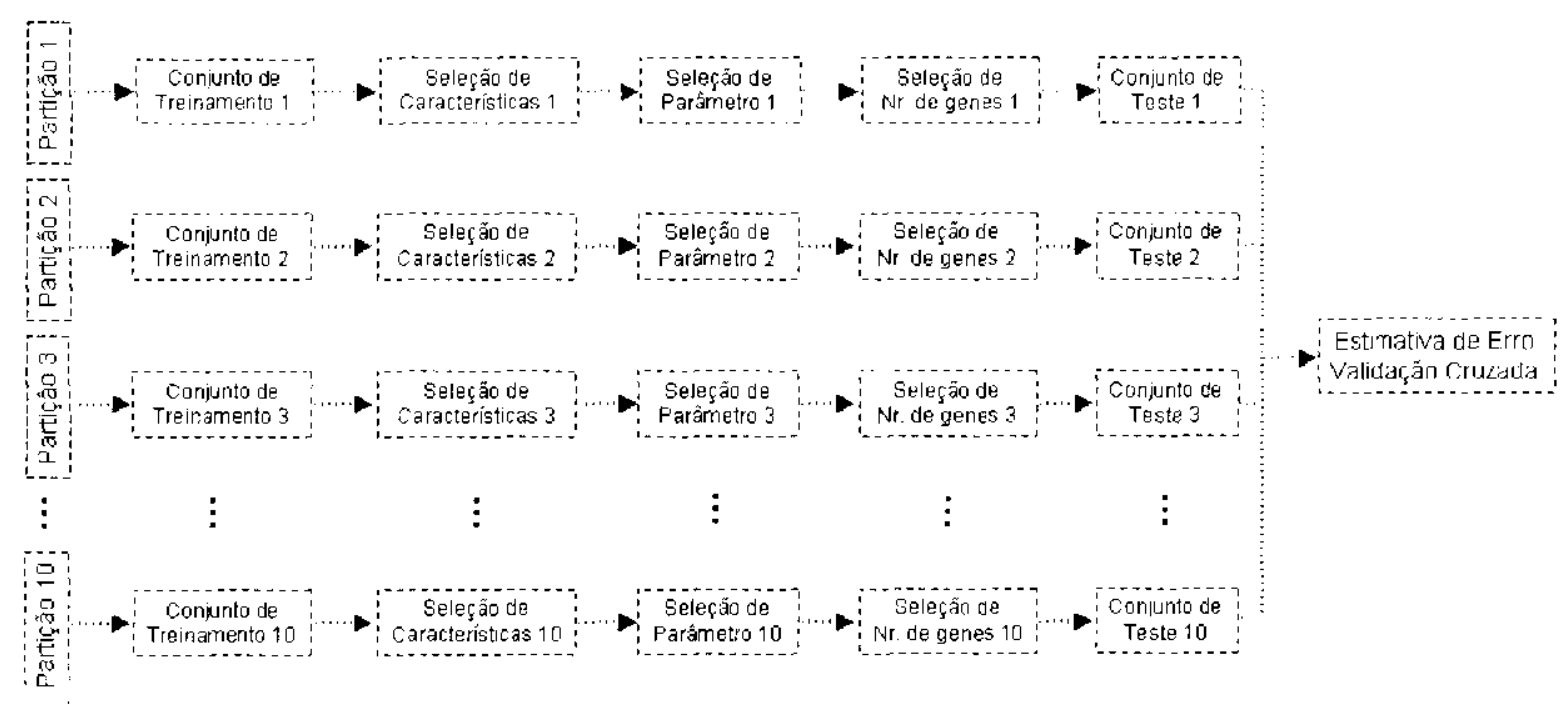

Figura 5.1: Metodologia utilizada nos experimentos.

Após a seleção de características, há uma etapa de seleção de valores dos parânu- 
tros. Peterson (2004) avalion o impacto do tipo de kiernel e: os valores dos parûnetros no desempenho de SVMs no domínio de expressão gênica por microamays. Ele concluiu que, quando da utilização do kernel linear, considerado neste trabalho, variaçóes no único parâmetro ajustável. o $C$, näo produzem diferenças de desempenho estatisticamento significativas. Em todo caso, para garantir que o desempenho da SVM tromada com os subconjuntos de genes selecionados pelos diversos métodos fosse maximizado, optou-se por selecionar o valor de $C$ que apresentasse o melhor desempenho en um esquema de LOOCV aplicado na partiço de treinamento. Foram considerados $C=\{1,10,100,1000\}$. No caso das tónican ntilizando $\mathrm{AG}, \mathrm{o} C=1000$ não foi considerato pois ocasionava um custo computacional demasiadamente elevado. O valor que apresentar o monor omo selecionado. No caso das abordagens do tipo filtro, o processo de selecaro de valores de parâmetros ocorre depois da seleção de genes. No caso las abordagens do tipo wrapper, as seleçôes de parâmetro e de genes ocorrm concomitantemente, pois o valor de $C$ influencia no processo de $\mathrm{SC}$.

A maioria dos algoritmos experimentados aqui não é capaz de determinar automaticamente o núnero de genes a sor selecionado. De fáto, apenas o CFS, a Consistência e as abordagen baseadas em $\Lambda \mathrm{G}$ o são. Nos demais casos, adotou-se a seguinte estratégia para determinar a dimensionalidade ótima: para cada base de dados, seleciona-se subconjuntos do $2,4,8,16,32,64,128$ e 256 genes. En cada uma das 10 partiçôes de darlos geradas, o erro de LOOCV na partição de treinamento é calculado e, ao final, tem-se 10 erros. A média destes é então utilizada para determinar o número de genes final. O número que apresentar menor média do erro de LOOCV é escolnido. En caso de mpate, o menor súmero é preferido.

Para os cxperimentos realizados neste Capítulo, os dados foram colocados enn escalal entre 0 e 1. Na abordagem de filtros, este processo é efetuado depois da aplicaçio da SC (exceto quando da utilização da técnica ReliefF, çue reculer que o processo scja teito antes). Nas abordagens de wrapper, o processo é efetuado antes da aplicação da SC; pois o processo de otimizaça das SVMs trabalha melhor com os dados assim representados.

\subsubsection{Teste estatístico}

Para aferir a significância estatística dos experimentos realizados neste Capítulo, utilizouse o teste t parcado baseado em validação cruzada de fator 10 (Dictterich, 1998). Este teste 
o utilizado para deteminar se há diforença entre as técnicas de seleçâo de caracteristicas ut,ilizados. Para sua aplicação, os dados devem encontrar-se particionados em 10 conjuntos disjuntos de treinamento o teste, criados conforme o processo de validaçäo cruzada visto anteriommente. Sendo A e B 2 classificadores troinados com características selecionadas por 2 métodos distintos de SC, ambos são treinados nos primeiros conjuntos e testados nos segundos. Assim, sejam $p_{A}^{(i)}$ e $p_{b}^{(i)}$ as proporções observadas de exemplos classificados incorretanente por $A$ e $B$, respectivamente, no i-ésimo conjunto de teste. Assumindo que as diferenças $p^{(i)}=p_{A}^{(i)}-p_{B 3}^{(i)}$ são anostradas independentemente de uma distribuição nurmal, entio pode-se aplicar o teste $t$, calculando a segunte estatística:

$$
t=\frac{\bar{p} \sqrt{n}}{\sqrt{\frac{\sum_{i=1}^{n}\left(p^{(i)}-\bar{p}\right)^{2}}{n-1}-}}
$$

onde $\bar{p}=\frac{1}{n} \sum_{i \ldots-1}^{n} p^{(i)}$ on $n=10$. Sobre a hipótese nula de que ambos os classificadores apresontam a mesma taxa de erro, a estatística $l$ tem uma distribuiçäo $t$ com $n$ - 1 graus de confianga. A hipótese nula é rejeitada se $\mid t_{\mid}>t_{n} 1_{, \alpha}$, onde $\alpha$ representa o nivel do confianca no teste. Comumente, ntiliza-se $\alpha=0,05$, indicando uma confiança de $95 \%$.

Embora o teste t, parcado baseado om validação cruzada apresente alguns problemas relacionados à suposição do independência dos dados (Dietterich, 1998), ele tem sido recentemente utilizado com sucesso para validar os resultados de métodos de SC no domínio de dados de cxpressão gênica (Potamias et al., 2004) (Inza et al., 2004).

\subsubsection{Métodos e seus parâmetros}

Os nétodos empregados neste estudo comparativo são aqueles apresentados no Capítulo 1 , a saber: Cl'S, Consistencia, 'Taxi de Ganho ('TG), Golub, Info, ReliefF, I'NoN, Wilcoxon, AROM e RFE. Os 8 primeiros sĩo do tipo filtro e os 2 últimos säo do tipo wrapper. Sáo também utilizadas as técnicas propostas bascadas em AGs. O filtro é extudado om suan 2 versóes: o AG-Filtro Corr e o AG-Filtro Cos. O urapper é o AG-SVM.

No ReliefF, 2 parâmetros precisam ser definidos pelo usuário. O primeiro é o número $k$ de vizinhos observados para realizar as estimativas de qualidade clas características. Seguindo a recomendaçio de Kononenko (1994), enn todos os experimentos tem-se $k=10$. Este valor também ó o padrão do ambiente Weka (Witten e Frank, 2000), utilizada nos experimentos dos métodos CFS, Consistência, 'TG e ReliefF. O segundo parâmetro é o número $m$ de iteraçoes do algoritmo. Em cada iteração, um exemplo é selecionado e 
seus vizinhos säo encontrados. Aqui, $m$ é igual ao numero de exemplos do conjunto de trcinamento e cada exempló é selecionado ma vez (Yu c Liu, 2004).

Os ACris utilizados apresentam diversos parâmetros a serem selecionados, conno a quantidade de indivíduos da população, o número de geraçoes pelas quais o algoritmo deve ser executado, os pesos dos componentes da função de aptidão, ete. Infelizmente, não há um consenso sobre una maneira sistemática de escolher os melhores valores destes parânotros. O que há disponivel na literatura é uma série de recomendações e estudos do caso que mostram que determinados valores podem ser adequados em certos domínios c sob condiçoes ospecificas. Isso faz com que o projetista do AG precise despender considerável (sforco e tompo ajustando os parâmetros para a sua aplicacão. As Tabelas 5.1 e 5.2 mostram os valores escolhirdos após alyuns estudos empíricos para as versóes do AG-Filtro o para o AG-SVM, respectivamente.

Tábela 5.1: Parânetros utilizados pelàs 2 versôes do AG-Filtro

\begin{tabular}{ccccc}
\hline População & Gerações & Prob. Cruzamento & $b_{1}, b_{2}, b_{3}$ & Freq. re-início \\
\hline 200 & 000 & 0.8 & $0.7,0.2,0.1$ & 25 \\
\hline
\end{tabular}

Com relação aos parânetros da função de aptidão das 2 versões do AG-Filtro, alğnus aspectos devem ser observados. Claramente, o mais importante termo da Equacão 4.26 co Val_indice $(\lambda)$. na medida em que ole reflete a qualidade geral dos agruparmentos. O termo Impure $a(\lambda)$ é utilizado para assegurar que o subconjunto de genes avaliado năo represente de mancira crrada os agrupamentos, ou seja, que exemplos de uma classe sojam mais similares aos agrupamentos de outras classes. O termo $V$ al indico $(\lambda)$ reduz csse problcma, mas nầo pode evitar sua ocorrência. Assimn. Impurcza $(\lambda)$ ć empregado. Finalmente. subconjuntos compactos de genes sào preferidos, dado que os outros requerimentos năo sejaln ałetados. O valores de $b_{1}, b_{2}$ e $b_{3}$ refletem todas estas observaçõos.

Consideraçoes semolhantes podem ser feitas no caso do $\Lambda$ G-SVM, onde o valor de $\operatorname{Erro}_{\xi \alpha}^{n}(\lambda)$ é o mais importante. () termo $\left(1-\right.$ Rank $_{n}$ ormol $\left.(\lambda)\right)$ serve para refinar a busca, permitindo que subeonjuntos com valores iguais de $\operatorname{Erro}_{\xi_{\alpha}}^{n}(\lambda)$ possan ser distinguidos. Por fun, um número reduzido de genes é almejado. Os valores dos parâmetros podem ser visualizados na Tabela 5.2 .

Os demais métodos não possuem parâmetros a serem ajustados. Além do Weka, foram utilizados a biblioteca em C/C++ galib (Wail, 1996), IJBSVM (Chang e Lin, 2001) e 
Tabela 5.2: Parâmetros utilizados pelo AG-SVM

\begin{tabular}{ccccc}
\hline População & Gerações & Prob. Cruzamento & $b_{1}, b_{2}, b_{3}$ & Freq. re-início \\
\hline 100 & 100 & 0.8 & $0.7,0.2 .0 .1$ & 25 \\
\hline
\end{tabular}

SVMLight (Joachims. 1998), para os experimentos envolvendo os AGs. Os mécodos Info, TNoN e Wilcoxon foran testados com o anxílio da ferramenta ScoreGones (Bon-Dor et al, 2000b). O RFE e o $A R O M$ estão implementados cm Matiab na forramenta de AM ('onleecida como Spider (Weston et al., 2003a).

Como os $\Lambda$ Gis säo métodos estocásticos, nảo há garantias de que os mesmos conjuntos de genes sejam sclecionados en diferentes execucoes do algoritmo. Fntretanto, para fins de comparação com out ros métodos de SC é útil ter-se apenas um subconjunto selecionado em cada partição do esquoma de validação cruzada. Assim, os AGs são exocutados jo vezes para calda partição e o indivíduo com melhor funça de aptidão ć malutido como a solıcão linal, que sorá comparada com aquelas geradas pelas outras técuicas.

\subsubsection{Objetivos}

Os experimentos realizados neste Capítulo têm os scguintes objetivos espocíficos:

- Comparar o desompenho de diversas técnicas de SC aplicadas a SVM. considerantosc tanto a taxa de erro do classificador quanto a taxa de redução de dimensionalidade do domínio. As bases de dados ntilizadas são provenientes de experimentos do microarrays.

- Conforme visto no Capítulo 4. os dados de expressão gênica possuem cortas propriedades que permitem supor que a aplicação de métodos de SC seja capaz do trazer benefícios para a elassificação utilizando algoritmos de AM, como SVMs. Assim, também ó objetivo deste capítulo verificar empiricamente se tal suposição pode sel concebida cono verdadeira.

- Durante este trabalho. desenvolveu-so 2 abordagens de SC baseadas om AGs. unin que se enquadra na concepça de filtros e a ontra na concepção de wrappers. Esto capítulo visa à comparaçăo destes com abordagens comumente encontradas na litcratura de SC para dados de expressiono genica. 
- Há una cnome variedade de técnicas de SC disponíveis. Neste trabalho, 13 são consideradas. Como cada um possui um bias distinto, assin como as bases do dados possuem diferentes características, pretende-se ainda recomendar que técnica utilizar em cada caso, afim de minimizar o erro de classificação.

\subsection{Bases de dados}

Todas as bases de dados utilizadas neste trabalho foram obtidas através de experimentos reais de microarrays. A maioria delas tem sido comumente utilizada na avaliação de técnicas de SC. Isto facilita a comparação entre as diversas abordagens encontradas na literatura. A seguir, as 5 bases experimentadas são brevemente comentadas.

- Leucemia. A base de dados de leucemia aguda têm sido largamente cstudada (Golub et al., 1999b). Ela consiste na expressão de 72 amostras obtidas a partir de microarrays de oligonucleotídeo contendo RNA de 6817 genes humanos. A tarefa é discriminar entre leucomia mielóide aguda (AML, do inglês acute myeloid leukemia)) o leucomia linfoblástica aguda (ALL, do inglès acute lymphoblastic leukemia). A base contém 47 amostras ALL e 25 mmostras AML. Seguindo procedimentos padrão de pré-processamento (Dudoit et al. 2002), todos os genes tiveram seu valor minimo de expressão $\mathrm{cm} 100$ e selı valor máximo en 16000 . Os genes $g$ tal que maximo $(g) /$ minimo $(g) \leq 50$ on maximo $(g)-\operatorname{minimo}(g) \leq$ 500 foram descartados. Assim, a base de dados finais compreende 3751 genes. Os dados podem ser obtidos em http://www.broad.mit, edu/cgi-bin/cancer/ publications/pub_paper.cgi?mode=viewkpaper_id=43

- Linforna. O linfona difuso de célula grande B é um grupo heterogêneo do tumor, de acordo con variações significativas na morfologia. na representação clínica e na resposta aos tratamentos (Lossos et al., 2000). Utilizando microarrays de DNA complementar, et al (2000) identificaram 2 forma molecularmente distintas de linfoma: o linfoma B do centro germinativo (GC, do inglês Germinal Centre B-like) $\mathrm{c}$ o linfoma $\mathrm{B}$ ativado (AB, do inglês Activated B-like). $\Lambda$ base contém 24 amostras GC e 23 amostras $A B$, representados por 4026 genes. Os dados podem ser obtidos em http://1lmpp.nih.gov/lymphoma/ 
- Cólon. Esta base compreende 62 amostras provenientes de microarrays de oligonucleotídeos que medem os nuiveis de expressão de 6500 genes humanos. Há 22 amostras nomuais e 40 amostias com câneer de cólon. Alon et al. (1999) forneceram a base de dados com 2000 genes, depois da eliminação daqueles com baixa intensidade do sinal. Os dados podem ser obtidos em http://microarray.princeton. edu/oncology/affydata/index.html

- Glioma. Nutt et al. (2003) estudaram a possibilidarle de utilizar dados de expressão gênica para classificar gliomas de alto gran. O seu escluema do classificagáo foi capaz de discriminar objetivanonte tumores gliais nãa convencionais, conseguindo taxas de acerto maiores que as técnicas bascadas em histopatologia. A base de dados consiste em 50 amostras provenientes de microarrmy de oligonucleotídeo, contendo RNA de aproximadamente 12600 genes. Há 14 glioblastomas (GB) convoncionais a 7 oligodendrogliomas anaplásticos convenciondis (OA). Há ainda 14 GB näo-convencionais e 15 OA não-convencionais. Os dados sío préprocessado tal que todos os genes tiveram sen valor múnimo de exprossão m 100 e seu valor máximo en 16000. Aqueles genes g cujo marimo $(g) /$ minimo $(g) \leq 3$ ou maximo(g) - minimo $(g) \leq 100$ foram descartados, restando 1434 genos. Os dados podem ser obtidos cm http://www.broad.mit.edu/cgi-bin/cancer/ publications/pub_paper.cgi?mode=view\&paper_id=82

- Mama. Dentre as diversas classificações dos tumores de mama, pode-se destacar aquelas que consideram o estrogênio para o desenvolvinento do tumor. (Os casos em que o hormonio provoca o crescimento desordenado das células săo chanados le FRt (do ingles Estrogen Receptor positive). Aqueles an que o hormonio näo influencia o tumor siur conhecidos como ER- (do ingles Estrogen Receptor negation). Ambos possuem caracteristicas gencticas distintas que poden elucidar o funcionamento do tumor e ajudar en seu diagnóstico e prognóstico. West et al. (2001) utilizaram microarrays de DNA complementar de 49 pacientes. Em 5 casos, os autores do estudo identificaram que a classificação utilizando as técnicas de imunohistoquínica e de Western Blotting apresentaram resultados conflitantes. Assim, decidiu-se excluir estas anostras dos experimentos aqui roalizaclos. A tarefa é discriminar entre 22 anostras ER+o 22 anostras ER-. Lodos os genes tiveram seu valor mínimo de expressián em 100 e sen valor máximo em 16000 . Os genes y tal 
que maximo $(g) /$ minimo $(g) \leq 50$ ou maximo $(g)-$ minimo $(g) \leq 500$ foram descartados, restando 5146 genes, de $11 m$ total de 7129 . Os dados podem ser obtidos em http://data.cgt.duke.edu/west.php

A fim de facilitar referências futuras, a Tabela 5.3 resume a descrição numérica das bases de dados utilizadas.

Tabela 5.3: Descriçâo nurnérica das bases de dados

\begin{tabular}{ccccc}
\hline Base de dados & $\begin{array}{c}\text { Número de } \\
\text { Amostras }\end{array}$ & Classe + & Classe - & $\begin{array}{c}\text { Número de } \\
\text { Genes }\end{array}$ \\
\hline Leucemia & 72 & $25 \mathrm{AML}$ & $47 \mathrm{ALL}$ & 3571 \\
Linfoma & 47 & $24 \mathrm{GC}$ & $23 \mathrm{AB}$ & 4026 \\
Cólon & 62 & 22 normais & 40 tumores & 2000 \\
Gliona & 50 & $28 \mathrm{~GB}$ & $22 \mathrm{OA}$ & 4434 \\
Mama & 49 & $22 \mathrm{ER}+$ & $22 \mathrm{ER}+$ & 5146 \\
\hline
\end{tabular}

\subsection{Resultados Experimentais}

Neste Seçào, os resultados obtidos nos experimentos conduzidos são apresentados. Para sua melhor visualização, eles são dispostos de maneira tabular, organizados por bases de dados. Assim, para cada mma das 5 bases utilizadas, há 3 tabelas. A primeira cxibe os erros percentuais médios de LOOCV obtidos pelas técnicas TG, Golub, Info, ReliefF, TNoN, Wilcoxon, AROM e RFF. São considerados subconjuntos de diferentes dimensionalidades. Com estas informações, é possível determinar o número ótimo de genes selecionados para cada método aplicado a uma base específica. Destaca-se em negrito o menor erro de LOOCV. Se houver mais de um caso com o mesmo erro, aquele com menor número de genes é destacado.

A segunda tabela contém os erros percentuais (média e desvio padrão) das SVMs nads 10 partiçoos de toste para cada técnica de SC. É mostrado também o erro utilizado-so todos os genes. Ao lado dos erros obtidos para cada técnica, há um símbolo indicando sua significância estatítica em relação ao conjunto completo de genes. Ela é calculada de acordo com o teste t parcado bascado $\mathrm{cm}$ validação cruzada de fator 10 , com $95 \%$ de confiança. () símbolo $\diamond$ indica que não ha diferença estatística entre ambos. O símbolo $\triangle$ 
indica que o mótodo de SC é estatisticamente superior. O símbolo $\nabla$ indica que a técnica de $\mathrm{SC}$ ó estatisticamente inferior. É exibido ainda o número (média/desvio padrão) de genes selecionados por cada método. Quando o desvio padrão é o. o mesmo número de genes é selecionado cm todas as partições.

A terceira tabela compara o desempenho entre as abordagens propostas e as demais técnicas. Ela apresenta dados indicando se a diferença entre os erros obscrvados utilizandose as técnicas é estatisticamente significante ou não. A notação de $\diamond, \Delta$ c $\nabla$ comentada anteriormente também é utilizada aqui, indicando se o método proposto é igual, melhor on pior. Ela tambén informa a relação entre as quantidades de genes selecionadas pelos métodos. Quando o sinal - está prescnte, o método proposto selecionou menos genens. Quando o sinal + está presente ocorreu o inverso. A comparação ć realizada aos pares.

\subsubsection{Leucemia}

Como pode ser visto na Tabela 5.4. a maioria dos métodos que não determina automaticamente o número de genes a screm selecionados apresenta as menores taxas de erros com muitos genes. Em todos os casos, os erros utilizando-se menos de 32 genes são altos. Isto ocorre porque quando poucos genes são considerados, cada um tem uma grande influência no erro. Se os genes nào forem realmente relevantes para o problema, o desempenho do classificador pode ser prejudicado. Fm contrapartida, quando há muitos genes, mesmo que nem todos sejam importantes, a interaça cntre eles pode trazer bencfícios para a classificação. A partir de 32 genes há uma tendência de que o crro decreşa à medida que se aumenta o múmero de genes.

É importante lembrar que a taxa de redução de dimensionalidade ó muito importante 120 domínio do expressão gênica, pois identificar um conjunto compacto de genes relevantes para o problema ajuda a racionalizar o emprego de tempo, de recursos financeiros e de pessoal nas pesquisas.

A Tabela 5.5 mostra que o cmprego de técnicas de SC é vantajoso na base de leucomia. Das 13 técnicas estudadas. 11 conseguiram reduzir a dimensionalidade sem sacrificar o desempenho de classificaçá da SVM. O AG-Filtro Corr e a Consistencia apresentaran desempenlo estatisticanente inferior em relação ao conjunto completo de genes. () fato do AG-Filtro Corr não ter obtido bom resultado nesta base deve ser interpretado como um indicativo de que a distância baseada em correlação não é apropriada para este caso, 


\begin{tabular}{ccccccccc}
\hline \multirow{2}{*}{ Método } & \multicolumn{8}{c}{ Número de genes } \\
\cline { 2 - 9 } & $\mathbf{2}$ & $\mathbf{4}$ & $\mathbf{8}$ & $\mathbf{1 6}$ & $\mathbf{3 2}$ & $\mathbf{6 4}$ & $\mathbf{1 2 8}$ & $\mathbf{2 5 6}$ \\
\cline { 2 - 9 } TG & $\mathbf{1 , 7 7}$ & 5.07 & 4,94 & 4,00 & 2,77 & 2,92 & 2,15 & $\mathbf{1 , 8 5}$ \\
Golub & 4,47 & 3,54 & 2,77 & $\mathbf{4 , 1 6}$ & 3,38 & $\mathbf{1 , 3 8}$ & $\mathbf{1 , 5 4}$ & 1,38 \\
Info & 5,08 & 4,46 & 5,55 & 2,77 & 2,31 & 2,76 & 2.00 & $\mathbf{1 , 5 4}$ \\
ReliefF & 8,16 & 6,47 & 4,47 & 3,24 & 3.24 & 2,00 & 2,15 & $\mathbf{1 , 6 9}$ \\
TNoN & 3,69 & 3,84 & 4,47 & 2,77 & 2,30 & 2,62 & 1.84 & $\mathbf{1 , 6 9}$ \\
Wilcoxom & 3,85 & 2,62 & 4,47 & 3,08 & 2,76 & 2,00 & 1,85 & $\mathbf{1 , 3 8}$ \\
\hline AROM & - & - & 0,15 & 0,15 & $\mathbf{0 , 0 0}$ & 0,00 & 0,00 & 0,00 \\
RFE & 2,92 & 1,07 & 0,15 & 0,15 & 0,46 & $\mathbf{0 , 0 0}$ & 0,00 & 0,30 \\
\hline
\end{tabular}

Tabela 5.4: Frro estimado (\%) utilizando diferentes números de gencs. Base de leucemia.

\begin{tabular}{lcr}
\hline Método & $\begin{array}{c}\text { Número de genes } \\
\text { (Média/Desvio) }\end{array}$ & $\begin{array}{r}\text { Erro (\%) } \\
\text { (Média/Desvio) }\end{array}$ \\
\hline Completo & $3571 / 0$ & $2,678 / 5,37$ \\
\hline AG-Filtro Corr & $10,00 / 1,26$ & $8,03 / 6,59 \nabla$ \\
AG-Filtro Cos & $3.50 / 0.5$ & $3,92 / 6,01 \diamond$ \\
CFS & $33,60 / 14,86$ & $5,17 / 8,46 \diamond$ \\
Consistência & $2,70 / 0,45$ & $15,05 / 12,12 \nabla$ \\
TG & 256 & $3,92 / 6,01 \diamond$ \\
Golub & $64 / 0$ & $3,92 / 6,01 \diamond$ \\
Info & $256 / 0$ & $3,92 / 8,21 \diamond$ \\
ReliefF & $256 / 0$ & $2,67 / 5,37 \diamond$ \\
TNoN & $253 / 0$ & $3,92 / 6,01 \diamond$ \\
Wilcoxon & $256 / 0$ & $5,17 / 8,46 \diamond$ \\
\hline AG-SVM & $15,60 / 1,80$ & $5,35 / 9,17 \diamond$ \\
AROM & $32 / 0$ & $2,67 / 5,66 \diamond$ \\
RFE & $64 / 0$ & $4,10 / 6,63 \diamond$ \\
\hline
\end{tabular}

Tabcla 5.5: Percentuais de crro de teste para cada lécnica. Base de leucomia. 
c não como uma falha das abordagens baseadas em AG. De fato, tanto a versão do filtro basearla no coseno quanto o wrapper propostos apresentaram resultados de classificação satisfatórios e com mon núnero muito reduzido de gernes.

Na 'labela 5.6, as téchicas propostas são comparadas com as demais abordagens na base de leucemia. O AG-Filtro Corr apresentou desempenho estatisticamente inforiores a 3 métodos e manteve-se igual aos restantes. O AG-SVM foi estatisticamente superior a Consistência e manteve desempenho igual ao dos demais métodos, embora tenha selecionado menos genes que a glande maioria deles. Dentre as abordagens wrappers, cle foi o que selecionou o conjunto mais compacto de genes, com diferença de no mínimo 2 vezes. () AG-Filtro Cos foi particularmente ben nesta base de darlos. Ela foi estatisticanente superior a 2 métodos e selecionon o menor número de genes entre os métodos de desempenho igual a ole. Desta forma, dados os resultados das 'Tabelas 5.6 e 5.5, o AG-Filtro Cos é o método recomendado para a base de leucomia.

\begin{tabular}{lccc}
\hline Método & AG-Filtro Corr & AG-Filtro Cos & AG-SVM \\
\hline AG-Filtro Corr & $\diamond(0.00 \mathrm{x})$ & $\triangle(-2,85 \mathrm{x})$ & $\diamond(+1,56 \mathrm{x})$ \\
AG-Filtro Cos & $\nabla(+2,85 \mathrm{x})$ & $\diamond(0,00 \mathrm{x})$ & $\diamond(+4,45 \mathrm{x})$ \\
CFS & $\diamond(-3,36 \mathrm{x})$ & $\diamond(-9,60 \mathrm{x})$ & $\diamond(-2,15 \mathrm{x})$ \\
Consistencia & $\diamond(+3,70 \mathrm{x})$ & $\triangle(+1,29 \mathrm{x})$ & $\diamond(+5,77 \mathrm{x})$ \\
TG & $\diamond(-25,60 \mathrm{x})$ & $\diamond(-73,14 \mathrm{x})$ & $\diamond(-16,41 \mathrm{x})$ \\
Golub & $\diamond(-6,40 \mathrm{x})$ & $\diamond(-18,28 \mathrm{x})$ & $\diamond(-1,10 \mathrm{x})$ \\
Info & $\diamond(-25,60 \mathrm{x})$ & $\diamond(-73,14 \mathrm{x})$ & $\diamond(-16,41 \mathrm{x})$ \\
ReliefF & $\nabla(-25,60 \mathrm{x})$ & $\diamond(-73,14 \mathrm{x})$ & $\diamond(-16,41 \mathrm{x})$ \\
TNoN & $\diamond(-25,30 \mathrm{x})$ & $\diamond(-72,28 \mathrm{x})$ & $\diamond(-16,21 \mathrm{x})$ \\
Wilcoxon & $\diamond(-25,60 \mathrm{x})$ & $\diamond(-73,14 \mathrm{x})$ & $\diamond(-16,41 \mathrm{x})$ \\
\hline AG-SVM & $\diamond(-1,56 \mathrm{x})$ & $\diamond(-4,45 \mathrm{x})$ & $\diamond(0,00 \mathrm{x})$ \\
AROM & $\nabla(-3,20 \mathrm{x})$ & $\diamond(-9,14 \mathrm{x})$ & $\diamond(-2,05 \mathrm{x})$ \\
RFF & $\diamond(-6,40 \mathrm{x})$ & $\diamond(-18,28 \mathrm{x})$ & $\diamond(-4,10 \mathrm{x})$ \\
\hline
\end{tabular}

Tabela 5.6: Comparação cntre os métodos propostos. Base de lencemia

\subsubsection{Linfoma}

A Jabela 5.7 exibe os crros de LOOCV da base de linfoma considerando subconjuntos de genes de diferentes dimensionalidades. Assim como ocorreu no onso da lencemia, 
observa-se uma tendência geral de diminniçăo do erro à medida que o número de genes aumenta. Nesta base. as abordagens do tipo urapper apresentaram erro de LOOCV bastante reduzido. O AROM, apresentou erro zero em todos os casos. Quando o número de genes é inferior a 8, o algoritmo não convergiu. Isto ocorren devido à limitação da implementação utilizada de só conseguir lidar com dados linearmente separáveis. Em dimensões reduzidas, isto se tornar mais difícil. O RFE matém o crro cm zero a partir de 16 genes.

Analisando a Tabola 5.8, verifica-se que a expectativa gerada pelas baixas taxas de cro de LOOCV no caso dos wrappers não se confirmou. Os 3 métodos desta abordagem apresentaram crros de testes inferiores aos filtros, em média. A exceção é o AG-Filiro Cos. que mostron-se inalequado para essa base. sendo estatisticamente inferior ao conjunto completo de genes. Todos os demais métodos lograram un dosmpenho de classificação ignal a conjunto completo de genes

Comparando-se as abordagens baseadas em AG. cujos dados são apresentados na Tabela 3. 9. constata-se que as abordagens AG-Filtro Cos e AG-SVM apresentann desempenho inforior à maioria dos filtros utilizados e desempenho igual a todos os wrappers. Em contraste, o AG-Filtro Corr ten taxas de erros estatisticamente iguais aos clemais mótodos o é superior ao AG-Filtro Cos. O número de genes selecionados por ele é menor em 7 situações e maior cm 5. A Consistencia selecionou o menor número de genes para esta base de darlos e não apresenta diferença estatística de desempenho em relação ao método que obteve o menor erro médio (0.00), o ReliefF. Assim. no caso do linfoma, o método de SC rocomendado é a Consistência.

\subsubsection{Cólon}

Através da Tabela 5.10, percebe-se que, para a base de cólon, o número ótimo de genes assume valores medianos. Na maioria dos métodos de SC utilizados, subconjuntos com poucos genes levam a erros de LOOCV elevados. O mesmo ocorre, entretanto menos severamente, quando se utiliza muitos genes, devido à introdução de genes possivelmente não relacionados ao fenômeno em estudo. Assim, os melhores erros nas abordagens do filtro ocorrem quando se utiliza 16 on 32 genes. O RFE necessita de 32 genes para conseguir seu menor erro. O AROM requer 64 genes. Este último método não convergiu com subconjunt os com menos de 16 genes. Isto mostra que esta base de dados é complexa 


\begin{tabular}{ccccccccc}
\hline \multirow{2}{*}{ Método } & \multicolumn{8}{c}{ Numero de genes } \\
\cline { 2 - 10 } & $\mathbf{2}$ & $\mathbf{4}$ & $\mathbf{8}$ & $\mathbf{1 6}$ & $\mathbf{3 2}$ & $\mathbf{6 4}$ & $\mathbf{1 2 8}$ & $\mathbf{2 5 6}$ \\
\hline TG & 4,71 & 3.99 & 4.48 & 3,30 & 2,34 & 0,70 & $\mathbf{0 , 4 7}$ & $\mathbf{1 , 1 6}$ \\
Golub) & 3,53 & 2,12 & 1,17 & 0,70 & $\mathbf{0 , 4 6}$ & 0,94 & 1,64 & 2.12 \\
Info & 4,96 & 5,19 & 4,95 & 3,53 & $\mathbf{1 , 4 1}$ & 1,65 & 1,41 & 1,41 \\
Relieff & 7,57 & 6,39 & 4,97 & $\mathbf{0 , 9 3}$ & 0,94 & 1,16 & $\mathbf{1 , 6 4}$ & 1,63 \\
TNoN & 5,43 & 5,20 & 3,99 & 4,01 & 2,12 & 2,12 & $\mathbf{1 , 8 8}$ & 1,89 \\
Wilcoxon & 4,73 & 3,31 & 2,12 & 0,69 & 0,94 & $\mathbf{0 , 2 3}$ & 1,87 & $\mathbf{1 , 6 4}$ \\
\hline AROM & - & - & $\mathbf{0 , 0 0}$ & 0,00 & 0,00 & 0,00 & 0,00 & 0,00 \\
RFE & 4,49 & 1,63 & 0,23 & 0,00 & 0,00 & 0,00 & 0,00 & 0,00 \\
\hline
\end{tabular}

Tabela 5.7: Frro estimado (\%) utilizando diferentes números de genes. Base de linfoma.

\begin{tabular}{lcr}
\hline Método & $\begin{array}{c}\text { Número de genes } \\
\text { (Média/Desvio) }\end{array}$ & $\begin{array}{r}\text { Erro (\%) } \\
\text { (Média/Desvio) }\end{array}$ \\
\hline Completo & $4026 /()$ & $5,66 / 8,69$ \\
\hline AG-Filtro Corr & $13,7 / 5,21$ & $4,00 / 8,00 \diamond$ \\
AG-Filtro Cos & $4,30 / 1,73$ & $19.66 / 16,00 \diamond$ \\
CFS & $35,30 / 7,36$ & $4,00 / 8,00 \diamond$ \\
Consistência & $2,60 / 0,40$ & $2,00 / 6,00 \diamond$ \\
TG & $128 / 0$ & $2,00 / 6,00 \diamond$ \\
Gulub & $32 / 0$ & $0,00 / 0,00 \diamond$ \\
Info & $32 / 0$ & $4,50 / 9,06 \diamond$ \\
ReliefF & $16 / 0$ & $5,00 / 10,00 \diamond$ \\
TNo.N & $128 / 0$ & $7,66 / 9,43 \diamond$ \\
Wilcoxon & $64 / 0$ & $6,00 / 9,16 \diamond$ \\
\hline AG-SVM & $11,10 / 3,53$ & $10,66 / 10,90 \diamond$ \\
AROM & $8 / 0$ & $12,66 / 14,61 \diamond$ \\
RFE & $16 / 0$ & $15,50 / 10,91 \diamond$ \\
\hline
\end{tabular}

Tabela 5.8: Percentuais de erro de teste para cada técnica. Base de linfoma. 


\begin{tabular}{lccc} 
Método & AG-Filtro Corr & AG-Filtro Cos & AG-SVM \\
\hline AG-Filtro Corr & $\diamond(0)$ & $\nabla(-3,18 \mathrm{x})$ & $\diamond(-1,23 \mathrm{x})$ \\
AG-Filtro Cos & $\triangle(+3,18 \mathrm{x})$ & $\diamond(0)$ & $\diamond(+2,58 \mathrm{x})$ \\
CFS & $\diamond(-2,57 \mathrm{x})$ & $\vee(-8,20 \mathrm{x})$ & $\diamond(-3,18 \mathrm{x})$ \\
Consistência & $\diamond(+5,26 \mathrm{x})$ & $\nabla(+1,65 \mathrm{x})$ & $\nabla(+4,26 \mathrm{x})$ \\
IG & $\diamond(-9,34 \mathrm{x})$ & $\vee(-29,76 \mathrm{x})$ & $\vee(-11,53 \mathrm{x})$ \\
Golub & $\diamond(+2,33 \mathrm{x})$ & $\nabla(-7,44 \mathrm{x})$ & $\nabla(-2,88 \mathrm{x})$ \\
Info & $\diamond(+2,33 \mathrm{x})$ & $\nabla(-7,44 \mathrm{x})$ & $\diamond(-2,88 \mathrm{x})$ \\
RelicfF & $\diamond(-1,15 \mathrm{x})$ & $\nabla(-3,72 \mathrm{x})$ & $\nabla(-1,44 \mathrm{x})$ \\
TNoN & $\diamond(-9,34 \mathrm{x})$ & $\nabla(-29,76 \mathrm{x})$ & $\diamond(-11,53 \mathrm{x})$ \\
Wilcoxon & $\diamond(-4,67 \mathrm{x})$ & $\nabla(-14,88 \mathrm{x})$ & $\diamond(-5.76 \mathrm{x})$ \\
\hline AG-SVM & $\diamond(+1,23 \mathrm{x})$ & $\diamond(-2,58 \mathrm{x})$ & $\diamond(0)$ \\
AROM & $\diamond(-1,71 \mathrm{x})$ & $\diamond(-1.86 \mathrm{x})$ & $\diamond(+1,38 \mathrm{x})$ \\
RFE & $\diamond(-1,15 \mathrm{x})$ & $\diamond(-3,72 \mathrm{x})$ & $\diamond(-1,44 \mathrm{x})$ \\
\hline
\end{tabular}

Tabela 5.9: Comparação ontre os métodos propostos. Base de linfoma

e apresenta muitos exemplos dificcis de classificar.

Este problema foi estudado por Kadota et al. (20)3). Eles desenvolveram um método que tenta identificar exemplos que foram detcrminados crroneanente como pertcncentes a unn classe (estes exemplos são conhecidos como outliers). A aplicação de seu método na base de cólon mostron que a heterogeneidade e a contaminação de amostras pode resultar on diversos outliers. Eles identificaram 7 casos. Assim, acredita-so que estes sấ os responsiveis pela al a complexidade de classificação desta base

Obscrvando a 'Tabela 5.11, percebe-se que a maioria dos métodos de SC conseguiu reduzir significativamente a dimensionalidade do domínio sem perda de desempenho de classificação. Apenas o CFS e o TG apresentaram resultados inferiores. Comparando as abordagens baseadas on AGs o as demais, percebe-se que năo há diforença de desempenho estatisticamente significante ontre os métodos. Tanto o AG-Filtro Corr quanto o AG-Filtro Cos selecionaram menos genes que a maioria das outras téenicas. Este último selecionon, en média, 3,60 genes é o método recomendado para a base de cólon. 


\begin{tabular}{ccccccccc}
\hline \multirow{2}{*}{ Método } & \multicolumn{10}{c}{ Número de genes } \\
\cline { 2 - 10 } & $\mathbf{2}$ & $\mathbf{4}$ & $\mathbf{8}$ & $\mathbf{1 6}$ & $\mathbf{3 2}$ & $\mathbf{6 4}$ & $\mathbf{1 2 8}$ & $\mathbf{2 5 6}$ \\
\hline TG & 17,19 & 17,37 & 12,53 & $\mathbf{1 1 , 8 1}$ & 12,89 & 12,90 & 14,51 & 18,26 \\
Gulub & 12,90 & 13,61 & $\mathbf{1 4 , 8 7}$ & $\mathbf{1 0 , 9 3}$ & 11,64 & 13,08 & 11,47 & 16,85 \\
Info & 15,76 & 13,96 & 11,81 & 12,35 & $\mathbf{1 1 , 4 6}$ & 13,25 & 13,43 & 14,15 \\
ReliefF & $\mathbf{1 5 , 4 1}$ & 15,41 & $\mathbf{1 4 , 6 8}$ & 14,69 & $\mathbf{1 2 , 7 2}$ & 14,86 & 13,96 & 15,94 \\
TNoN & 14,15 & 14,33 & 14,33 & $\mathbf{1 2 , 8 9}$ & $\mathbf{1 2 , 5 3}$ & 13,07 & 13,07 & 13,07 \\
Wilcoxon1 & $\mathbf{1 4 , 8 7}$ & 13,26 & 12,36 & $\mathbf{1 1 , 1 0}$ & 11,28 & 11,64 & 11,10 & 13,61 \\
\hline AROM & - & - & - & 0,72 & 1,61 & $\mathbf{0 , 3 6}$ & $\mathbf{1 , 4 3}$ & 2,15 \\
RFE & 13,61 & 7,51 & 3,01 & 1.44 & $\mathbf{0 , 5 3}$ & 0,72 & 1,25 & 1,61 \\
\hline
\end{tabular}

Tabela 5.10: Erro estimado (\%) utilizando diferentes números de genes. Base de cólon

\begin{tabular}{lcr}
\hline Método & $\begin{array}{r}\text { Número de genes } \\
\text { (Média/Desvio) }\end{array}$ & $\begin{array}{r}\text { Erro (\%) } \\
\text { (Média/Desvio) }\end{array}$ \\
\hline Completo & 2000 & $12.61 / 11.71$ \\
\hline AG-Filtro Corr & $9,20 / 0,40$ & $15,71 / 15,32 \diamond$ \\
AG-Filtro Cos & $3,60 / 1,62$ & $14,28 / 15,20 \diamond$ \\
CFS & $21,80 / 5,96$ & $19,04 / 13,76 \nabla$ \\
Consistetencia & $4,3 / 0,78$ & $14,28 / 13,25 \diamond$ \\
TG & $16 / 0$ & $25,23 / 20,92 \nabla$ \\
Golub & $16 / 0$ & $14,28 / 15,20 \diamond$ \\
Irfo & $32 / 0$ & $15,95 / 14,44 \diamond$ \\
RoliefF & $32 / 0$ & $12,61 / 13,88 \diamond$ \\
TNoN & $32 / 0$ & $14,04 / 14,69 \diamond$ \\
Wilcoxon & $16 / 0$ & $15,4762 / 16,60 \diamond$ \\
\hline AG-SVM & $17,90 / 3,80$ & $15,71 / 13,93 \diamond$ \\
AROM & $64 / 0$ & $17,38 / 17,57 \nabla$ \\
RFE & $32 / 0$ & $19,28 / 24,39 \diamond$ \\
\hline
\end{tabular}

Tabela 5.11: Percentuais de erro de teste para cada tócnica. Base de cólon. 


\begin{tabular}{lccc}
\hline Método & AG-Filtro Corr & AG-Filtro Cos & AG-SVM \\
\hline AG-Filtro Corr & $\diamond(0)$ & $\diamond(+2,55 x)$ & $\diamond(1,94 \mathrm{x})$ \\
AG-Filtro Cos & $\diamond(+2,55 \mathrm{x})$ & $\diamond(0)$ & $\diamond(+4,97 \mathrm{x})$ \\
CFS & $\diamond(-2,36 \mathrm{x})$ & $\diamond(-6,05 \mathrm{x})$ & $\diamond(-1,21 \mathrm{x})$ \\
Consistência & $\diamond(+2.13 \mathrm{x})$ & $\diamond(-1.19 \mathrm{x})$ & $\diamond(+1,16 \mathrm{x})$ \\
TG & $\diamond(-1,73 \mathrm{x})$ & $\Delta(-4,44 \mathrm{x})$ & $\Delta(+1,11 \mathrm{x})$ \\
Golub & $\diamond(-1,73 \mathrm{x})$ & $\diamond(-4,44 \mathrm{x})$ & $\diamond(+1,11 \mathrm{x})$ \\
Info & $\diamond(-3,47 \mathrm{x})$ & $\diamond(-8,88 \mathrm{x})$ & $\diamond(-1,78 \mathrm{x})$ \\
RolielF & $\diamond(-3,47 \mathrm{x})$ & $\diamond(-8,88 \mathrm{x})$ & $\diamond(-1,78 \mathrm{x})$ \\
T.NoN & $\diamond(-3,47 \mathrm{x})$ & $\diamond(-8,88 \mathrm{x})$ & $\diamond(-1,78 \mathrm{x})$ \\
Wilcoxon & $\diamond(-1.73 \mathrm{x})$ & $\diamond(-4,44 \mathrm{x})$ & $\diamond(+1.11 \mathrm{x})$ \\
\hline AG-SVM & $\diamond(-1.94 \mathrm{x})$ & $\diamond(-4,97 \mathrm{x})$ & $\diamond(0)$ \\
AROM & $\diamond(-6,95)$ & $\diamond(-17,77 \mathrm{x})$ & $\diamond(-3,57 \mathrm{x})$ \\
RFE & $\diamond(-3,47 \mathrm{x})$ & $\diamond(-8,88 \mathrm{x})$ & $\diamond(-1,78 \mathrm{x})$ \\
\hline
\end{tabular}

Tabela 5.12: Comparação entre os métodos propostos. Base de cólon.

\subsubsection{Glioma}

A Tabela 5.13 compara os erros do LOCOV de subenjuntos de genes de diferentes dimensionalidades na base de glioma. Percebe-se que os menores erros são obtidos utilizando-se 8, 16 ou 32 genes. É interessante notar a grande diferença entre os erros obtidos pelos filtros e pelos wrappers. Isto ocorre pelo fato de os erros de LOOCV serem calculados lias mesmas partiçoes de treinamento utilizadas para selecionar os genes. Como nos wrappers o chassificador é ativamente utilizado para selecionar os genes, é natural que os crros obtidos com o mesmo classificador empregado anteriomente sejam pequenos. Esta mesma situaçàno ocomreu na base de cólon.

Observando-se a Tabela 5.14, percebe-se que utilizando as particõos de teste, os wrappers não apresentaram dusempenho diferente dos filtros. em média. Todas as técnicas foram rapazes de selecionar subconjuntos compactos de genes sem interferir significantemente no desempenho das SVMs. Embora a maioria das técnicas tenha obtido desempenho de classificação semelhante, nota-se que a taxa de erro pode ser considerada alta. Isto ocorre pois a base é formada do amostras bastante heterogencas, compostas de casos de glioma clásssicos e não-clássicos Nutt et al. (2003). Estes uiltimos são difíceis de classificar 


\begin{tabular}{|c|c|c|c|c|c|c|c|c|}
\hline \multirow{2}{*}{ Método } & \multicolumn{8}{|c|}{ Número de genes } \\
\hline & 2 & 4 & 8 & 16 & 32 & 64 & 128 & 256 \\
\hline $\mathrm{TG}$ & 17,99 & 13,76 & 13,99 & 11,10 & 10,65 & 11,97 & 13,76 & 15,51 \\
\hline Golub & 19,31 & 13.32 & 11,99 & 11,99 & 13,54 & 12,87 & 12.42 & 12,88 \\
\hline Infor & 17,99 & 16,86 & 14,89 & 12,88 & 12,21 & 14,20 & 14,66 & 16,87 \\
\hline RoliefF & 18,91 & 15,09 & 12,20 & 12,66 & 13,53 & 13,09 & 13,54 & 15,30 \\
\hline $\mathrm{TNoN}$ & 15,52 & 15,10 & 13,99 & 13,76 & 15,32 & 15,33 & 16,67 & 15,97 \\
\hline Wilcoxon & 16.44 & 15,10 & 13,12 & 14,00 & 14,22 & 14.64 & 16,85 & 17,08 \\
\hline AROM & - & - & - & 0,22 & 0,44 & 0.67 & 0,44 & 0.44 \\
\hline RFE & 15.31 & 9.09 & 2,65 & 0,00 & 0,66 & 0,00 & 0,22 & 0,44 \\
\hline
\end{tabular}

Tabela 5.13: Erro estimado (\%) utilizando diferentes números de genes. Base do glioma. ató mesmo por nuédicos experientes.

A Tabela 5.15 apresenta uma comparação entre as abordagens haseadas em AGs e as demais técnicas. () AG-Filtro Corr apresentou desempenho inferior ao ReliefF a ao AG-SVM. O desempenho do AG-Filtro Cos foi igual ao de todas as técnicas, ombora tenha selecionado menos genes na maioria das vezes. O AG-SVM mostrou ter desempenho superior ao de diversas técnicas. Para isso, entretanto, ele necossitou de um maior número de genes en quase todos os casos.

Para esta base, tanto o AG-Filtro Cos quanto o ReliefF poderiam ter sido recomondos, pois o desempenho de ambos não é diferente estatisticamente e cles sclecionaram. em média, 7 e 8 genes, respectivamente. Fntretanto optou-se por recomendar o Relieff, dado que o seu crro médio foi de $16.00 \%$, enquanto que o AG-Filtro Cos teve um erro médio de $23,66 \%$. Além disso. o ReliefF foi significantemente superior ao AG-Filtro Corr, CFS, Wilcoxon, $\Lambda$ ROM c RFE.

\subsubsection{Mama}

A Tabela 5.16 compara o erro de LOOCV utilizando diferentes técnicas de SC e diversos números de genes. Para esta base de dados, percebe-se que as dimensionalidades dos subconjuntos selecionados variam muito de acordo com a técnica utilizada, indo de apenas 4 até 256 gencs. Lambém para esta base, o AROM não conseguiu convergir quando o múmero de genes é muito pequeno. 


\begin{tabular}{lcr}
\hline Método & $\begin{array}{c}\text { Número de genes } \\
\text { (Média/Desvio) }\end{array}$ & $\begin{array}{r}\text { Erro (\%) } \\
\text { (Média/Desvio) }\end{array}$ \\
\hline Completo & $4434 / 0$ & $21,00 / 17,82$ \\
\hline AG-Filtro Corr & $9,90 / 1,30$ & $25,66 / 18,54 \diamond$ \\
AG-Filtro Cos & $7,00 / 2,36$ & $23,66 / 20,06 \diamond$ \\
CFS & $35,60 / 3,46$ & $27,50 / 18,33 \diamond$ \\
Consistência & $3,90 / 0,53$ & $23,66 / 15,23 \diamond$ \\
TG & $32 / 0$ & $17,66 / 14,51 \diamond$ \\
Golub & $8 / 0$ & $22,16 / 22,48 \diamond$ \\
Info & $16 / 0$ & $25,83 / 19,13 \diamond$ \\
ReliefF & $8 / 0$ & $16,00 / 14,41 \diamond$ \\
TNoN & $16 / 0$ & $26,16 / 20,24 \diamond$ \\
Wilcoxon & $8 / 0$ & $28,16 / 22,39 \diamond$ \\
\hline AG-SVM & $20,20 / 4,85$ & $17,16 / 15,16 \diamond$ \\
AROM & $16 / 0$ & $23,83 / 19,59 \diamond$ \\
RFE & $16 / 0$ & $25,83 / 20.17 \diamond$ \\
\hline
\end{tabular}

T'abela 5.14: Percentuais de erro de teste para cada técnica. Basc de glioma.

\begin{tabular}{lccc}
\hline Método & AG-Filtro Corr & AG-Filtro Cos & AG-SVM \\
\hline AG-Filtro Corr & - & $\diamond(-01,41)$ & $\Delta(+02,04)$ \\
AG-Filtro Cos & $\diamond(+01,41)$ & - & $\diamond(+02,88)$ \\
CFS & $\diamond(-03,59)$ & $\diamond(-05,08)$ & $\triangle(-01,76)$ \\
Consistência & $\diamond(+-02,53)$ & $\diamond(+01,79)$ & $\Delta(+05,17)$ \\
TG & $\diamond(-03,23)$ & $\diamond(-04,57)$ & $\diamond(-01,58)$ \\
Golub & $\diamond(+01,23)$ & $\diamond(-01,14)$ & $\diamond(+02,52)$ \\
Info & $\diamond(-01,61)$ & $\diamond(-02,28)$ & $\triangle(+01,26)$ \\
RelicfF & $\nabla(+01,23)$ & $\diamond(-01,14)$ & $\diamond(+02,52)$ \\
TNoN & $\diamond(-01,61)$ & $\diamond(-02,28)$ & $\Delta(+01,26)$ \\
Wilcoxon & $\diamond(+01,23)$ & $\diamond(-01,14)$ & $\diamond(+02,52)$ \\
\hline AG-SVM & $\nabla(-02,04)$ & $\diamond(-02,88)$ & - \\
AROM & $\diamond(-01,61)$ & $\diamond(-02,28)$ & $\diamond(+01,26)$ \\
RFE & $\diamond(-01,61)$ & $\diamond(-02,28)$ & $\diamond(+01,26)$ \\
\hline
\end{tabular}

Tabela 5.15: Comparação entre os métodos propostos. Base de glioma. 


\begin{tabular}{ccccccccc}
\hline \multirow{2}{*}{ Método } & \multicolumn{7}{c}{ Número de genes } \\
\cline { 2 - 10 } & $\mathbf{2}$ & $\mathbf{4}$ & $\mathbf{8}$ & $\mathbf{1 6}$ & $\mathbf{3 2}$ & $\mathbf{6 4}$ & $\mathbf{1 2 8}$ & $\mathbf{2 5 6}$ \\
\hline TG & 3,02 & 1,77 & 4,02 & 4.05 & 3,01 & 3,27 & 2,01 & $\mathbf{0 , 7 5}$ \\
Golub) & 5,78 & 3,01 & 1,25 & 3.03 & 1.76 & 2.02 & $\mathbf{0 , 7 6}$ & 0,76 \\
Inlo & 2.51 & 2,02 & 5,53 & 3,77 & 4,02 & 3.27 & $\mathbf{1 , 5 1}$ & $\mathbf{1 , 7 6}$ \\
ReliefF & 6.59 & 5,56 & 3.03 & 3,52 & 2.77 & 3.27 & 2.53 & $\mathbf{2 , 0 1}$ \\
T.NoN & 2,76 & $\mathbf{1 , 5 2}$ & 3.77 & 3,55 & 5.28 & 3,77 & 3.03 & 2,28 \\
Wilcoxon & 3,27 & $\mathbf{1 , 2 7}$ & 2.52 & 3,28 & 3,28 & 4,53 & 1,52 & $\mathbf{1 , 7 8}$ \\
\hline AROM & - & - & 0.5 & $\mathbf{0 , 0 0}$ & 0,00 & 0,00 & 0,00 & 0,00 \\
RFF & 5.30 & 0,5 & $\mathbf{0 , 0 0}$ & 0.00 & 0,00 & 0.00 & 0.00 & 0.00 \\
\hline
\end{tabular}

Tabela 5.16: Erro estimado (\%) utilizando diferentes números de gencs. Base de mama.

A Tabela 5.17 exibe os erros de teste aplicando-se as várias ténicas. 'Todas elas apresentam desempenho estatisticamente igual em relação à classificação realizada utilizando o conjunto completo de genes,indicando a efićcia da SC na base. Neste experimento, 2 técnicas de SC sobressaíram: o CFS c a Consistência. Ambas obtiveram um erro médio de 1,66\%, selecionado apcnas 1 gene. Assim, tanto um quanto outro podem ser recomendados. Os dois apresentaram desempenho estatisticamente superior ao Golub, ao 'INoN, ao RFE e ao AG-Filter Cos. O AG-Filtro Cos e o AG-SVM não apresentaran diferença significante em ralação a nenhuma técnica. como pode scr visto na Tabela 5.18.

\subsection{Genes Selecionados}

Nesta Seção os genes selecionados utilizando as técnicas recomendadas para cada base de dados são mostrados. A selcção não é mais baseada nas partições de treinamento da validação cruzada e sim nas bases completas. Desta forma, para as técnicas que determinam automaticamente o número de genes a ser selecionados, pode haver cortas discrepâncias em relação aos números exibidos nas tabclas anteriores e os números exibidos nesta Seção. No caso das técnicas que selecionam un número definido de genes. utiliza-so os melhores valores conforme visto na Seção 5.4 .

Para a base de leucemia, a técnica de SC utilizada ć o AG-Filtro Cos. Os genes selecionados sāo apresentados na Tabela 5.19, com as identificações e descriçóes conforme disponibilizados pelo provedor original da base de dados. Ao todo, 7 genes foram selecio- 


\begin{tabular}{lcr}
\hline Método & $\begin{array}{c}\text { Número de genes } \\
\text { (Média/Desvio) }\end{array}$ & $\begin{array}{r}\text { Erro (\%) } \\
\text { (Média/Desvio) }\end{array}$ \\
\hline Completo & $4969 / 0$ & $10,00 / 16,58$ \\
\hline AG-Filtro Corr & $9,20 / 0,40$ & $6,66 / 10,40 \diamond$ \\
AG-Filtro Cos & $3,80 / 0,97$ & $9,16 / 11,45 \diamond$ \\
CFS & $1 / 0$ & $1,66 / 5,00 \diamond$ \\
Consistenncia & $1 / 0$ & $1,66 / 5,00 \diamond$ \\
TG & $256 / 0$ & $6,66 / 10,40 \diamond$ \\
Golub & $128 / 0$ & $9,16 / 11,45 \diamond$ \\
Info & $128 / 0$ & $6,66 / 10,40 \diamond$ \\
ReliefF & $256 / 0$ & $4,16 / 8,53 \diamond$ \\
TNoN & $4 / 0$ & $9,16 / 11,45 \diamond$ \\
Wilcoxon & $4 / 0$ & $6,66 / 10,40 \diamond$ \\
\hline AG-SVMI & $26,5 / 7,29$ & $6,66 / 10,40 \diamond$ \\
AROM & $16 / 0$ & $4,16 / 9,00 \diamond$ \\
RFE & $8 / 0$ & $10,83 / 14,19 \diamond$ \\
\hline
\end{tabular}

'Tabela 5.17: Percentuais de erro do teste para cada técnica. Base de mama.

\begin{tabular}{lccc}
\hline Método & AG-Filtro Corr & AG-Filtro Cos & AG-SVM \\
\hline AG-Filtro Corr & $\diamond(0)$ & $\diamond(-2,42 \mathrm{x})$ & $\diamond(+2,88 \mathrm{x})$ \\
AG-Filtro Cos & $\diamond(+2,42 \mathrm{x})$ & $\diamond(0)$ & $\diamond(+6,97 \mathrm{x})$ \\
CFS & $\diamond(+9,20 \mathrm{x})$ & $\nabla(+3,80 \mathrm{x})$ & $\diamond(+26,50 \mathrm{x})$ \\
Consistência & $\diamond(+9,20 \mathrm{x})$ & $\nabla(+3,80 \mathrm{x})$ & $\diamond(+26,50 \mathrm{x})$ \\
TG & $\diamond(+27,82 \mathrm{x})$ & $\diamond(-67,36 \mathrm{x})$ & $\diamond(-9,66 \mathrm{x})$ \\
Gohub & $\diamond(-13,91 \mathrm{x})$ & $\diamond(-33,68 \mathrm{x})$ & $\diamond(-4,83 \mathrm{x})$ \\
Info & $\diamond(-13,91 \mathrm{x})$ & $\diamond(-33,68 \mathrm{x})$ & $\diamond(-4,83 \mathrm{x})$ \\
ReliefF & $\diamond(-27,82 \mathrm{x})$ & $\diamond(-67,36 \mathrm{x})$ & $\diamond(-9,66 \mathrm{x})$ \\
TNoN & $\diamond(+2,30 \mathrm{x})$ & $\diamond(-1,05 \mathrm{x})$ & $\diamond(+6,62 \mathrm{x})$ \\
Wilcoxon & $\diamond(+2,30 \mathrm{x})$ & $\diamond(-1,05 \mathrm{x})$ & $\diamond(+6,62 \mathrm{x})$ \\
\hline AG-SVM & $\diamond(-2,88 \mathrm{x})$ & $\diamond(-6,97 \mathrm{x})$ & $\diamond(0)$ \\
AROM & $\diamond(-1,73 \mathrm{x})$ & $\diamond(-4,21 \mathrm{x})$ & $\diamond(+1,65 \mathrm{x})$ \\
R.FE & $\diamond(+1,15 \mathrm{x})$ & $\diamond(-2,10 \mathrm{x})$ & $\diamond(+3,31 \mathrm{x})$ \\
\hline
\end{tabular}

Tabela 5.18: Comparação entre os métodos propostos. Base de mama. 
nados.

\begin{tabular}{|c|c|}
\hline 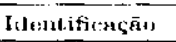 & Des:riç̇̈, dos genes \\
\hline DAR270 at & 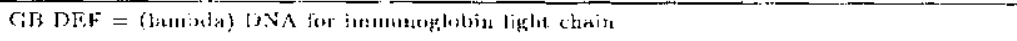 \\
\hline N216162t at & 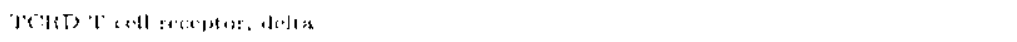 \\
\hline M127391.nt & 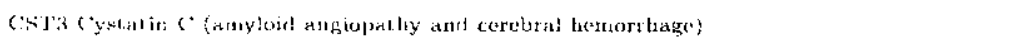 \\
\hline 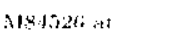 & 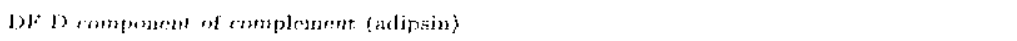 \\
\hline 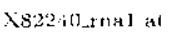 & 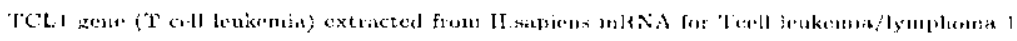 \\
\hline U89022, & LTB Lymphoutex:II-betn \\
\hline$X(10) \cdot 15 T^{\circ}$ a at & 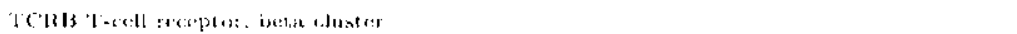 \\
\hline
\end{tabular}

'labela 5. 19: Identificação e descriçño dos genes selecionados. Base de lencomir.

Para a base do linfoma, a técnica de SC utilizada é a Consistêncja. Os genes selecionados são apresentados na Tabela 5.20, com as identificaçöes e descriçóss conforme disponibilizados pelo provedor original da base de dados. Ao todo, 3 genes foran selerionados.

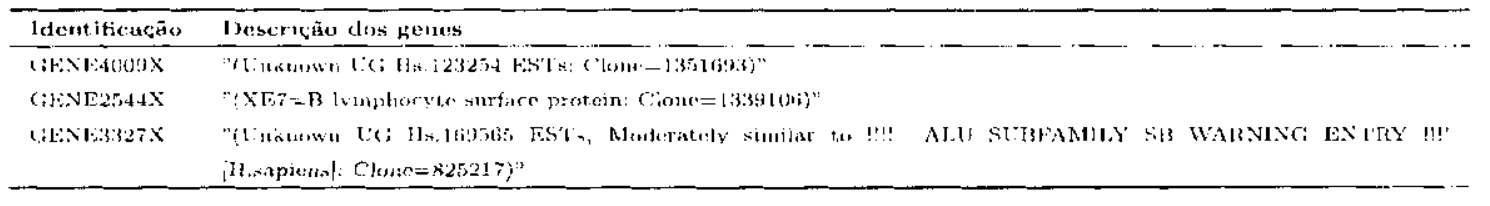

Tabela 5.20: Identiffoção e descrição dos genes selecionados. Base de linfoma.

Para a basedo cólon a técnica de SC utilizada é a Consistencia. Os genes selecionados săo apresentados na Tabela 5.21. com as identificaçós e descriçós conforme disponibili\%ados pelo provedor original da base do dados. Ao todo, 13 genes foram selecionados.

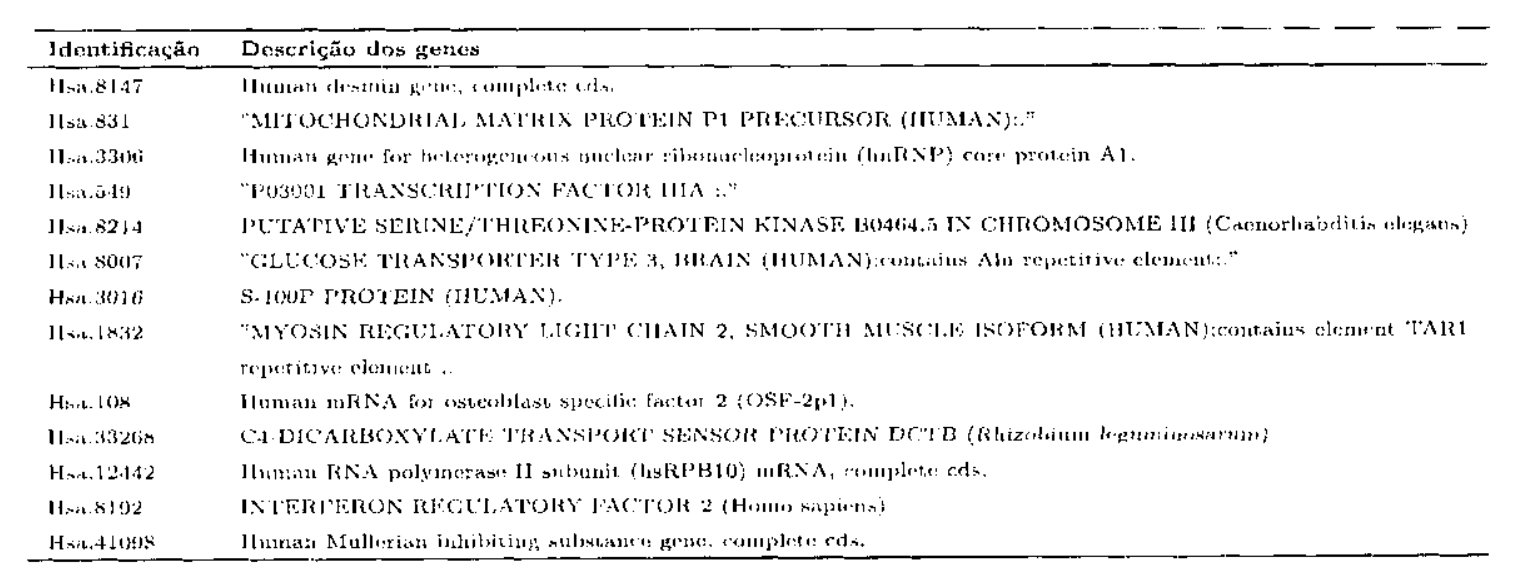

Tabela 5.21: Identilicação e descrição dos genes sclecionados. Base de cólom.

Para a base de glioma, a técnica de SC utilizada é a RelicfF. Os genos sclecionados são apresentados na labela 5.22, com as identilicaçoes e descrições conforme disponibilizarlos pelo provedor original da base do dados. Ao todo, 8 genes foram selecionados.

Para a base de mama, as técnica de SC utilizadas são a Consistencia e o CFS. Os geues solecionados são apresentados na Tabela 5.23, com as identificaçón e descriçöes conformo 


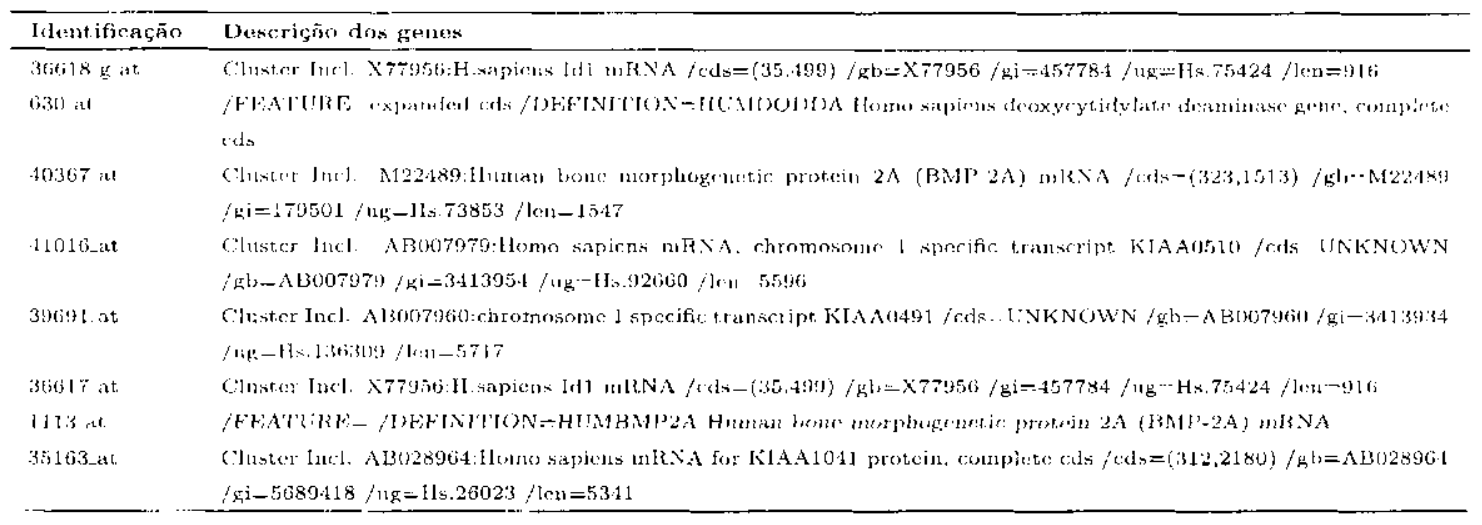

I'abela 5.22: Identificação o descrição dos genes selecionados. Base de glioma.

disponibilizados pelo provedor original da base de dados. Ao todo, um único grene foi selecionado por ambas as técnicas.

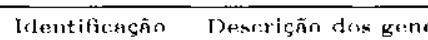

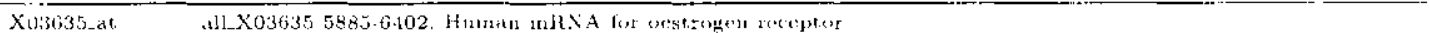

Tabela 5.23: Identificanăo e descrição dos genes sclecionados. Base de mama.

\subsection{Considerações finais}

Neste Capítulo, os experimentos realizados durante este trabalho foram apresentados. Comparon-se diversas técnicas de SC aplicadals a bases reais do expressão gênica e alguma conclusões, relacionadas com os objetivos cmumerados na Seção 5.2.4, puderam ser tecidas:

1. As técnicas de SC podem ser aplicadas eficazmente aos dados de microarrays. As taxas de redução obtidas foram muito boas, fazendo com que em todos os domínios testados o múmero de genes considerados passasse de alguns milhares para poncas dezenas on mesmo midades. Além disso, na maioria dos casos, os conjuntos compactos de genes não produziram diferença significativa no desempenho das SVMs, quando comparados ao conjunto completo de genes.

2. As abordagens desenvolvidas baseadas em AGs apresentaran bons desempenhos na classificacão pelas SVMs. Os filtros AG-Filtro Corr e AG-Filtro Cos foran alternando o bom desempenho nas bases testadas. Em todas elas, ao menos uma das versões teve desempenho estatisticannente igual às demais técnicas. Em 2 situaçós, o AG-Filtro Cos foi o método recomendado. O AG-SVM mostrou ter o melhor de- 
sempenho geral entre os wrappers utilizados, tanto em redução de dimensionalidade do problema quanto na classificação pelas SVMs.

3. Avaliando os experimentos como um todo, pode-se concluir que os filtros aprescmtaram benefícios em relação aos wrappers. Geralmente, eles selecionaram menor múmero de genes e obtiveram desempenho médio de classificação superior. Isto é corroborado pelo fato de que todas as técnicas recomendadas säo filtros.

Destacou-se também os genes selecionados pelas molhores técnicas en cada base. Hles săo pouco o suficiente para serem analisados eficientemente em experiências de bancada. Assim, espera-se que dis técnicas de SC possam ser úteis para médicos c biólogos envolvidos no tratamento de doenças graves.

Una comparacão direta de custo computacional das técnicas não é possível. Primeiro porque os experimentos, dependendo da técnica empregada, foram executadas em máquinas com configurações diferentes. Segundo, os programas utilizados estão em lingungens de programação das mais variadas, como $\mathrm{C} / \mathrm{C}++$. Matlab e Java, dificultado as análises. Mas, como regra geral, afirma-se que todos os filtros foram executados com grande oficiência computacional. Sous tompos de execução variam de alguns segundos a poncon minutos, mesmo o AG-Filtro Corr e o AG-Filtro Cos. Os métodos que realizam um ranking das características forann os mais rápidos, como o esperado. Os wrappers envolvem naturalmente mais custos de processamento, levam muitos minutos a algumas horas para serem executados. O AG-SVM mostrou ser mais custoso. Apesar de tudo, quando analisando dados de expressão gênica, o custo computacional não deve ser encarado como a maior prioridade. Basta lembrar que cles representann una fração muito pequena dos custos envolvidos em projetos maiores, que vão desde a difícil coleta dos dados biológicos à custosa e demorada conduçâa dos experimentos de microarrays. 


\section{Capítulo 6}

\section{Conclusão e Trabalhos Futuros}

No prescnte trabalho, foi apresentada una comparaçăo cntre diversos métodos de SC para SVMs aplicadas à análise de bases de dados de expressão gênica. Foram considerados 8 filtros a 2 wruppers para sclecionar genes em experimentos de microarrays. Os principais objetivos do estudo foram observar se SVMs poderia ter algum benefício cm trabalhar com um conjunto compacto de genes neste domínio e indicar quais as melhores técnicas para as 5 bases testadas, tanto em termos de desempenho do classificador quanto em termos de redução de dimensionalidade.

No decorrer do projeto, 2 novas técnicas bascadas em AGs foram desenvolvidas. $A$ primeira pode sor enquadrada na abordagem de filtros. Ela bascia-se nas características intrínsecas dos dados para selecionar um subconjunto de genes que melhor represente o domínio. A outra é um urapper para SVMs. Ela utiliza algumas propriedades e resultados teóricos do classificador para selecionar os genes que. explicitamente, mais influenciam na classificaçâo.

Os resultados comparativos entre todas as técnicas mostraram 3 pontos básicos:

- AGs são muito eficazes no problema da seleção de genes. Em todas as bases testadas, 011 o AG-Filtro (em uma de suas versões) ou o AG-SVM, apresentaram descmpenho de classificaçăo nào estatisticamente inferior às demais técnicas e com um número bastante reduzido de genes. De fato, em 2 bases, o AG-Filtro Cos foi a técrica recomendada. A técnica AG-SVM foi o melhor entre os urappers testados.

- Os resultados mostram que os filtros são mais adequados que os wrappers para realizar SC en domínios de expressão genica, onde o número de exemplos do dados chega a ser centenas de vezes menor que o número de genes. Nestas situações, os wrappers parecem confrontar-so com o problema do overfitting.

- As taxas de reduçào de dimensionalidade obtidas são altamente positivas. Em todos os casos tostados, apenas uma pequena fragão de genes foi selecionada, em comparagăo com os milhares disponíveis. Trabalhar com poucos genes é vantajoso nás 
experiências de bancada efetuadas por médico e biólogos. Assim, os cientistas podem focar esforços o recursos nos genes que mais provavelmente estão relacionado com o fenômeno cm estudo

\subsection{Contribuições}

Este trabalho resultou nas seguintes contribuições principais:

- Uma comparação de diversas técnicas de SC aplicados a bases de dados reais de expressão gênica. Com isso, foi possível determinar a melhor técnica para cada bases c apresentar os genes selecionados para cada uma. Fstes genes podem, posteriormente, ser estudados nais profundamente.

- O desenvolvimento de 2 novas abordagens para selecionar genes. Elas são baseadas cm AGs c mostraran ser competitivas com os métodos comparados. Tanto o AGFiltro quanto o AG-SVM resultaram em publicação de trabalhos científicos (de souza e de Carvalho, 2004b) (de Sonza et al., 2004).

- O fortalecimento do recém-criado Grupo de Computação Bioinspirada do ICMCUSP. () trabalho encontra-se perfeitamente alinhado com a linha de pesquisa do grupo e ajuda na missâo de desenvolver soluçoes inspiradas na natureza para resolver problemas de Bioinformática.

\subsection{Trabalhos Futuros}

Dentre os trabalhos que podem ser desenvolvidos a partir deste, é possivel citar:

- Este trabalho restringiu-se às bases do dados provenientes do microarrays, por estas serem mais comuns e estarem disponíveis publicamente na Intenet. Entretanto, há várias outras tecnologias que têm sido utilizadas para gerar dados genômicos cm laraga escala, como o SAGE e o MPSS. Assim, espera-se poder aplicar as técnicas aqui testadas nestes outros tipos de dados.

- Lina validação biológica crítica dos genes selecionados poderia enriquecer o estudo. Desta fornda é intenção do autor trabahthar cm conjunto com uma equipe especiali7adia para verificar a relevância dos subconjuntos encontrados. 
- As técnicas proposias são bascados em AGs simples. Recentemente, versoes multiobjotivas têm sido ntilizadas om problema de SC (Jr. et al., 2004). No contexto de dados de expressão genica o SVMs o autor desconhece algum trabalho. Futão, investigar cstias abordagens ó de interesse do autor.

- Teste trabalho, apenas bases de dados contendo 2 classes foram consideradas. Entretanto, muitos problemas reais são multiclasse o apresentam toda mma nova sério do dificuldades. Assim, pretemde-so explorar este tipo de problemals. Unala primeiral tentativa já foi feita ntilizando AGs e SVMs (de souza e do Carvalho. 2004a).

- O sucesso dos AGs na seleçäo de genes instiga a pesquisa dessa aplicação ntilizandoso outros algorimos bio-inspirados, como Colonias de Formigas (Cambardella a aj., 2002). Inteligencia por Enxame (de Oliveira et al. 20(3). ele. O autor tem interesse em investigar essas abordagens nm oportunidado próxima. 


\section{Referências Bibliográficas}

Alon, U., Barkai. N.. Notterman. D. A., Gish, K., Ybarra. S.. Mack, D., and Levine, A. J. (1999). Broad pattems of gene expression revealed by clustering analysis of tumor $\mathrm{e}$ normal colon tissues probed by oligonucleotide arrays. In Proc Natl Acad Sci USA. volume 96, pages 6745 6750. National Academy of Sciences.

Ambroisc, C. o McLachlan, G. J. (2002). Selection bias in gene extraction on the basis of microarray gene-expression data. PNAS USA, 99(10):6562 6566.

Argani, P., lacobuzio-Donahue, C., Ryu, B., Rosty, C., Goggins, M., Wilentz, R. F., Murngesan, S. R., Leach, S. D., Jaffee, E., Yeo, C. J., Cameron, J. L., Kern, S. E., e Hruban. R. H. (2001). Mesothelin is overexpressed in the vast majority of ductal adenocarcinomas of the pancreas. Clinical Cancer Research, 7:3862-3868.

Ben-Dor, A.. Bruhn, L., Friedman, N., Nachman. I, Schummer, M., e Yakhini, Z. (2000a). Tissue classification with gene expression profiles. In RECOMB. pages 54-61.

Ben-Dor, A., Friedman, X., e Yakhini, Z. (2000b). Scoring gones for relevance. Relatório Técnico 2000-13, Agilent Laboratories. EUA.

Ben-Dor. A., Friedman, N., e Yakhini, 7. (2002). Overabundance analysis e class discovery in genene. Relatório Técnico 2002-4. Agilent Laboratories. EUA.

Bishop, C. M. (1996). Neural networks for pattern recognition. ()xford University Press.

Blum, A. e Langley, P. (1997). Selection of relevant features e examples in machino: learning. Artificial Intelligence, $97(1-2): 245-271$.

Breman, I., Friedman. J., Olshen, R.. e Stone, C. (1984). Classification e Regression. Trees. Wadsworth International, California. 
Brenner, S., Johnson, M., Bridgham, J., Golda, G., Lloyd, D. H., Johnson, D., Luo, S. MeCurdy, S., Foy, M., Ewan, M.. e Roth, R. (2000a). Genes expressed in the drosophila head reveal a role for fat cells in sex-specific physiology. Nature Technology, 18:630 634 Errata em Nat, Biotechnol 2000 Jun:18:630-634.

Bromer, S., Willians, S. R., Vermaas, E. H., Storck, T., Moon, K., MeCollum, C., Mao, J.-I., I.uo, S., Kirchner, J. J., Fletr, S.. DuBridge. R. B., Burcham, T., o Albreht G. (2000h). In vitro cloning of complex mixtures of dna on microbeads: Physical separation of differentially expressed cdnas. In Proc Natl Acad Sci USA, volume 97 pages 1665-1670. National Acaderny of Sciences.

Brown, M. P'. S., Grundy, W. N., Lin, D., Cristianini, N., Sugnet, C., Jr., M. A., e Hanusster D. (2000). Support vector machine classification of microarray gene expression data In Proc Natl Acad Sci USA, volume 97, pages 262-267. National Academy of Scioncess.

B3urges, C. J. C. (1998). A tutorial on support vector machines for pattern recognition. Data Min. Knowl. Discov. 2(2):121-167.

Cai, J., Dayanik, A., Yu, H., Hasan, N., Tranuchi, T., c Grundy, W. N. (2000). Classification of cancer tissue types by support vector machines using microarray gene expression data. In The Eighth International Conference on Intelligent Systems for Molecular Biology (ISMB), California, USA. Poster.

Caldwell, M. C.. Hough, C., Fürer, S., Linehan. W. M., Morin, P. J. and Gorospe, M. (2002). Serial analysis of wene expression in renal carcinoma cells reveals vhl-dependent sensitivity to tuf cytotoxicity. Oncogene, 21:929-936.

Cascy, D. K. (2001). Genomics e its impact on medicino o society: A 2001 primer. Technical report, U.S. Department of Energy. Human Genome Program.

Casley, D. (1992). Primer on molecular genetics. Technical Report, U.S. Departmente of Energy, Office of Energy Research, Office of Health e Fnvironmental Research.

Chang: C.-C. c Lin, C.-J. (2001), LIBSVM: a library for support vector machines. Software available at http://www.csie.ntu.edu.tw/ ${ }^{\sim} \mathrm{cjlin} / \mathrm{libsvm}$. 
Choi, S. (2004). DNA Chips e Microarray Analysis: An Overview, chapter Handbook of fungal biotechnology, pages 173 - 179. Marcel Dokker, Inc, New York, second edition edition.

Collins, F. S., Green, E. D., Guttmacher, A. F., e Guyer, M. S. (2003). A vision for the future of genomics research. Nature, $422: 835-847$.

Congdon. C. B. (1995). A comparison of genetic algorithm e other machine leaming systems on a complex classification task from common disease rescarch. Phd thesis, University of Michigan.

Constans, A. (2002). A new approach to gene expression analysis. The Scientist, 16:44.

Cover: T. M. e Thomas, J. A. (1991). Elements of Information Theory. John Wiley e Sons, Nova York.

Cristianini, N. e Shawe-Taylor, J. (2000a). An Introduction to Support Vector Machines (and other kernel-based learning methods). Cambridge University Press. Cambridgo, CK, 1 edition

Cristianini, N. e Shawe-Taylor, J. (2000b). An Introduction to Support Vector Machines (and other kemel-based learning methods). Cambridge University Press.

de Oliveira, D. Jr.. P. R. F., Bazzan, A. I. C. c Klügl, F. (2004). A swarm-based approach for selection of signal plans in urban scenarios. In ANTS Workshop, pages $116-417$.

de souza, B. F. e de Carvalho, A. (2004a). Gene selection based on multi-class svms o genctic algorithms. In Proceedings of the WOB 20004, pages 1-8, Brasila.

de souza, B. F. o de Carvalho, A. (2004b). Gene selection using genetic algorithms. In Procedings of the 1st International Symposium on Biological e Medical Data Analysis, Lecture Notes in Computer Science, pages 1-12, Valencia, Espanha. Springer-Verlag.

de Souza, B. F., de Carvalho, A., e Cancino, W. (2004). Gene subset selection using genetic algorithm o svms. In Procedings of SBRN 2004. ILEE. 'lo be published.

Deb, K. e Kalyamoy, D. (2001). Multi-Objective Optimization Using Evolutionary Algorithms. John Wiley \& Sons. Inc. 
Dietterich. T. G. (1998). Approximate statistical tests for comparing supervised classification learning algorithms. Neural Computation. 10(7):1895-1924.

Ding: C. e Dubchak, I. (2001). Multi-class protein fold recognition using support vector machines e neural networks. Bioinformatics, 17:349--358.

Dragomir, A., Mavroudi, S., e Bezerianos. A. (2004). Som-based class discovery exploring the ica-reduced features of microarray expression profiles. Comparative e Functional Genomics, 5(8):596 616

Dubitzky, W., Granzow, M., e Berrar, D. (2001). Comparing symbolic e subsymbolic machine learning approaches to classification of cancer e gene identification. In Lin, S. ๑.Johnson. K., editors, Methods of Microarray Data Analysis: Papers from CAMDAS̆OO. Kluwer Academic Publishers.

Duda, R. O., Hart, P. E., e Stork, D. G. (2000). Pattern Classification (2l Ediçäo). Wiley-Interscience

Dudoit, S. Fridlyand, J.. c Specl, 'T. P. (2002). Comparison of discrimination methods for the classification of tumors using gene expression data. Journal of the American Statistical Association, 97(457):77-87.

Duggan, D. J., Bittner, M., Chen, Y., Meltzer, P., e Trent, J. (1999). Expression profiling using cdna microarrays. Nature, 21:10 14

Eisen, M. B., Spellman. P. 'T., Brown, P. O., e Botstein, D. (1998). Cluster analysis e display of genome-wide cxpression patierns. In Proc Natl Acad Sci USA, volume 95, pages 14863-14868. National Academy of Sciences.

Emmanouilidis, C'., Hunter, A.. e Naclntyre, J. (2000). A multiobjective evolutionary sctting for feature sclection e a commonality-based crossover operator. In Procedings of the Congress on Evolutionary Computation 00, pages 309-316, New Jersey. IEEE Press.

Ermolacva, O., Rastogi, M., Pruitt, K. D., Schuler, G. D., Bittner, M. L., Chen, Y., Simon, R., Mcltzer, P., Trent, J. M., e Boguski, M. S. (1998). Data management e analysis for gene cxpression arrays. Nature Genetics, 20:19-23. 
et al, A. A. A. (2000) . Distinct types of diffuse large b-cell lymploma iclentified by genc expression profiling. Nature, 403:503-511.

et al, K. D. (20)(2). Evaluation of simple performance measures for tuning svm hyperparameters. Neurocomputing, 51:41-59.

Filho, I. G. C. (2003). Comparative analysis of clustering methods for gene expression data. Dissertação de mestrado, Centro de Informática, Universidade Federal de Pernambuco, Recife.

Friedman, N., Linial, M., o Nachman, I. (2000). Using bayesian network to analyze expression data. In Proceedings of the Forth Annual Conference on Research in Computational Molecular Biology RECOMB ŚO0, pages 127 135. ACM Press.

Fujiii, S. e Amrein, H. (2002). Genes expressed in the drosophila head reveal a role for fat colls in sex-specific physiology. Clinical Cancer Research, 21:5353-5363.

Gambardella, L. M., Dorigo, M., Middendorf, M., e Stiitzle, T. (2002). Guest editorial: special section on ant colony optimization. IEEE Trans. Evolutionary Computation, $6(1): 317: 319$

Gibson, G. e Muse S. V. (2004). A Primer of Genome Science, chapter Gene Expression o the Transcriptome, pages $123-181$. Sinauer Associatcs, Inc., Sunderland, second edition edition.

Goldberg, D. E. (1989). Genetic Algorithms in Search, Optimization e Machine Learning. Addison-Wcsley Longman Publishing, Boston, MA.

Golub, T. R., Slonim, D. K., Tamayo. P., c Ifuard, C. (1999a). Molecular classification of cancer: Class discovery e class prediction by gene expression monitoring. Scichec, 286.

Golub, T. R., Slonim, D. K., Tamayo, P., Huard, C., Gaasenbeek, M., Mesirov, J. P., Coller, H., Loh, M. L., Downing, J. R., Caligiuri, M. A., Blomineld, C. D., e Lander, E. S. (1999b). Molecular classification of cancer: Class discovery e class prediction by gene expression monitoring. Science, 286:531 537.

Guyon, I. e Elissecf, A. (2003). An introduction to variable e feature selection. J. Mach. Learn. Res., 3:1157 1182. 
Gnyon, I., Weston, J., Barnhill, S., e Vapnik. V. (2002). Gene selection for cancer classification using support vector machines. Machine Learning, 46 (1-3):389-422.

Hall, M. e Holmes, G. (2003). Benchmarking attribute sclection techniques for discrete class data mining. IEEE Trans. Knowl. Data Eng., 15(6):1437-1447.

Hall, M. A. (1999). Correlation-based feature selection for machine learning. Tese de doutorado, Departament of Computer Science, Lniversity of Waikato, Hamilton, New Zealand.

Harrington, C. A., Rosenow, C., e Retief, J. (2000). Monitoring gene expression using dna microarrays. Curr. Opin. Microbiol., 3:285 Ü 291.

Haykin, S. (1998). Neural Netuorks: A Comprchensive Foundation. Prentice Hall PTR, Upper Saddle River, NJ, USA.

Hucka, M. e Szallasi, Z. (2003). Introduction to computational approaches in systems biology. Online.

Hunter, L. (1993). Molecular biology for computer scientists. In Hunter, L., editor, Artificial Intclligence e Molccular Binlogy: pages 1-46. Menlo Park, CA. AAAI Press.

Hwang, K.-B., Cho, D.-Y., Park, S.-W., Kim, S.-D., e Zhang, B.-'l'. (2002). Applying machine learning techniques to analysis of gene expression data: cancer diagnosis. In Lin, S. e Johnson, K., cditors, Methods of Microarray Data Analysis, pages 167-182, Boston, USA. Kluwer Academic Publishers.

Inza, I., Larraniga, P., Blanco, R., e Cerrolaza, A. J. (2004). Filter versus wrapper gene selection approaches in dna microarray domains. Artificial Intelligence in Medicine, 31:91Ũ103.

Jaeger, J., Sengupta, R., e Ruzzo, W. L. (2003). Improved gene selection for classification of microarrays. In Proceedings of the Pac Symp Biocomput. 2003, pages 53-64. Eletronic: version available at http://helix-web.stanford.edu/psbo3/.

Jain, A. c Chandrasekaran, B. (1982). Dimensionality e sample size considerations. Pattern Recognition Practice, 2:835-855. 
Jain. A. Dubes, R. (1988). Algorithms for Chustering Data. Prentice Fall, Englewood Cliffs. N.J.

Jain, A. K., Duin, R. P. W., c Mao. J. (2000). Statistical pattem recognition: A review. IEEE Transactions on Pattern Analysis o Machine Intelligence, 22(1):4 37.

Joachims, T. (1998). Making large-scale support vector machine learning practical. In B. Schölkopf, C. Burges, A. S., editor. Advances in Kernel Methods: Support Vector Machines. MIT Press, Cambridge, LA.

Joachims, T. (2000). Estimating the generalization performance of a SVM efficiently In Langley, P., cditor, Proce of 17th ICML-00, pages 431-438, Stanford, US. Morgan Kaufmann Publishers, San Francisco, LS.

Joachims, T. (2002). Learning to Classify Text using Support Vector Machines: Mothods, Theory, algorithms. KLUWER INTERAATIONAL SERIES IN ENGINEERING $\mathrm{O}$ COMPUTER SCIENCE. Kluwer Academic Publishers, Norwell, MA.

Joel, W., Bock, R., e Gongh, D. A. (2001). Predicting protein-protein interactions from prinuary structure. Bioinformatics, 17:455-460.

John, G. II., Kohavi, R., e Pfleger, K. (1994). Irrelevant features o the subset solection problem. In International Conference on Machine Learning, pages 121-129. Journal version in AIJ, available at http://citeseer.nj.nce.com/13663.html.

Jr., C. S., Pappa, G., Freitas, A., e Kaestner, C. (2004). Antomatic text summarization with genetic algorithun-based attribute selection. In Lemaitre, C., Reyes, C., c Gonzales, J., cditors, Advances in Artificial Intelligence (IBERAMIA 2004, Proc. 9th IberoAmerican Conference on AI), LNCS, volume 3315, pages 305-314. Springer-Verlag.

Kadota, K., Nishimura, S. I., e Bono. H. (2003). Detection of genes with tissur-specific expression pattems using akaikc's informationcriterion procedure. Physiol. Genomics, $12(3): 251-259$

Kim, R. D. e Park, P. J. (200)4). Improving identification of differentially expressed genes in microarray studies using information from public databases. Genome Biol., 5(9):R70). 
Kira, K. e Rendell, L. A. (1992). A practical approach to feature selection. In Procecdings of the Intermational Conference on Machine Learning (ICML92), page 249U256, EUA. Morgan Kanifmann.

Kohavi, R. e John, G. H. (1997). Wrappers for feature subset selection. Artificial Intelligence, $97(1-2): 273 \quad 324$.

Kohavi, R. e Sommerfield, D. (1995). Feature subset selection using the wrapper method: Overfitting and dynannic search space topology. In Proc. 1st Intl. Conf. on Knowledge Discovery e Duta Mining, pages 166-185, Menlo PArk, CA. AAAI Press.

Koller, D. e Sahami. M. (1996). Toward optimal feature selection. In International Conference on Machine Learning, pages 284-292.

Kononenko, I. (1994). Estimating attributes: Analysis e extensions of RELIEF. In Furopean Conference on Machine Learning, pages 171-182.

Kuranochi. M. e Karypis, (․ (2001). Gene classification using expression profiles: A fersibility study. In BIBE, pages 191200.

Li, L. cet al (2001). Gene assessment e sample classification for gene expression data using a genetic algorithm/k-nearest neighbor. Method. Combinat. Chem. e High Throughput Screening, 4:727 739 .

Lin, Y. $(2000)$. the support vector machine.

Lipshlute, R. J., Fuchor, S. P., Gingeras, 'T. R., o Lockhart, D. J. (1999). High density synthotic oligonucleotide arrays. Nature Genetics, $21: 2024$.

Liu, H., Hussain, F., Tan, C., e Dash, M. (2002). Discretization: An enabling techmique. Sournal of Data Mining e Knowledye Discovery, 6(4):3933 423.

Liu, H. r. Motoda, H. (1998a). Feature Selection for Knomledge Discovery e Data Mining. Kluwer Acadentic: Publishers, Norwell, MA, USA.

I.iu, H. c Motoda, H. (1998b). Frature selection for knowledge discovery data mining.

Liu, H. o Setiono, R. (1996). A probabilistic approach to feature selection - a filter solution. In International Conference on Machine. Learning, pages 319-327. 
Lodish, H., Berk, A., Zipursky, L., Matsudaira, P., Baltimore, D., e Damell, J. (1999). Molccular Cell Biology. W.II. Freman, New York, 4 edição edition.

Lornad, A. C. (2002). Utilização de técnicas de margens largas na análise de dados biológicos. Qualificação, Instituto de Ciências .Hatemáticas o de Computação ICMC/CSP, São Carlos.

Lossos, I. S., Alizadeh, A. A., Eisen, M. B., e Brown, P. (). (2000). Ongoing immunoglobulin somatic mutation in germinal center b cell-like but not in activated b coll-like diffuse large cell lymphomas. Proc Natl Acad Sci U S A, 97(18):10209 13.

Nendel. G. (1865), Versuche über pflanzen-hybriden. Verhandlungen des Naturforschenden Vereines in Bruenn, IV:3-47. Tradução para o inglés foita por C.T. Drucry o William Batcson disponivel cm http://www. mendelweb.org/Mendel.html.

Michalski, R. S., Carbonell, J., e Mitchell, T. M. (1983). Machine Learning: an Artificial Intelligence Approach. Morgan Kaufinann l'ublishers, Inc.

Notoda. II. e Liu. H. (2002). Feature selection, extraction o construction. In Towards the Foundation of Data Mining Workshop, Gz̈ Pacicif-Asia Conference on Knowledge Discovery e Dala Mining (PAKDDS̈OQ), page 67Ü72, 'laipei, 'Taiwan.

Mukherjee. S. (2003). Classifying microarray data using support vector machines. In Berrar. D., Dubitzky, W. o Gran\%ow. M.. editors, Understanding e Using Microarray Analysis Techniques: A Practical Guide. pages 166-185, Boston/Dordrecht/London. Kluwer Academic Publishers.

Mukherjee, S., Tamayo, P., Slonim, D., Verri, A., Golub, T.. Mesirov, J., and Poggio, T. (1999). Support vector machine classification of microarray data.

Ng, R. T., Sunder, J., e Sleumer, M. C. (2002). Hicrarchical cluster analysis e classification of sage data. In The 10 th International Conference on Intelligent Systems for Moleculur Biology (ISMB). Edmond. Canada. Poster.

Ngnyen, D. V. (2005). Partial least squares dimension reduction for microarray gene expression data with a consored response. Math Biosci., 193(1):119 37. 
Noble, W. S. (2001). Kernel Methods in Computational Biology, chapter Support vector machine applications in computational biology, pages 71-92. MITT Press, Cambridge, MA

Nutt, C. L., Mani, D. R., Betensky, R. A., c Tamayo, P. (2003). Gene expression-based classification of malignant gliomas correlates better with survival than histological classification. Cancer Res., 63(7):1602-7.

Okura, V. K. (2002). Bioinformática de projetos genoma de bactérias. Dissertação, LNICAMP: Campinas, SP

Ooi, C. H. e Tan, P. (2003). Genetic algorithms applied to multi-class prediction for the analysis of gene expression data. Bioinformatics. 19(1):37-34.

Peron, C. M., Sørlie. T.. Eisen, M. B., van de Rijn. M.. Jeffrey, S. S., Rees, C. A., Pollack, J. R.. Ross, D. 'I., Johnsen, H., Akslen, L. A., Øystein Fluge, Pergamenschikov, A., Willians, C., Zhu. S. X., Lonning, P. E., Børresen-Dale, A.-L., Brown, P. O., e Botstein, D. (2000). Nolecular portraits of human breast tumours. Nature, 406:747 752.

Peterson. D. A. (2001). Svm model selection for microarray classification. Poster Session at Eighth Annual International Conference on Research in Computational Molecular Biology (RECOMB 2004).

Potamias, G., : e ct al (2004). Gene sclection via discretized gene-expression profiles e greedy feature-elimination. In Proceedings of the SETN 2004. volume 3025 of LNCS, pages 256 266. Grécia. Springer Verlag.

Quackenbush. J. (2001). Computational analysis of microarray data. Nat Rev Genet. $2(6): 418-27$

Rakotomamonjy, A. (2003). Variable selection using svm based criteria. J. Mach. Leam. Res.. 3:1357-1370.

Schcha, M. (1999). DNA Microarrays: A Practical Approach. Practical Approach Series. Oxford University Press, Oxford, Inglaterra, 1$\}$ edition.

Shamir, R. Torok, D., e Shtainhart, A. (2002a). Analysis of gene cxpression data, dra chips e gene networks lecture notes. 
Shamir, R., Iorok, D. o Shtainhart, A. (2002b). Analysis of gene expression data. dna ships e gene networks lecture notes.

Sharan, R., Elkon, R., e Shamir, R. (2002). Chster analysis e its applications to gene expression data. In Ernst Schering Res Found. Workshop, volume 38, pages 83-108.

Silva, F. H. (2001). Módulo: Biologia molecular. In I Escola Brasileira de Inteligência Artificial e Bioinformática InBio Säo Carlos, São Carlos.

Slonim, D. K., Tamayo. P., Mesirov, J. P., Golub, T. R., e Lander, E. S. (2000). Class prediction e discovery using gene expression data. In IRECOMB: pages 263-272.

Smola, A. J. e Schoolkopf. B. (2002). Learning with Kernels. MIT P'ress.

Spellman, P. T', Sherlock, G., Zhang, M. Q., lyer, V. R.. Anders, K., Eisen, M. B., Brown, P. O., Botstein. D., e Futcher, B. (1998). Comprehensive identification of coll cycle-regulated genes of the youst saccharomyces cerevisiae by nicroarray hybridization. Molecular Biology of the Cell, 9:3273 3297.

Stollberg, J., Urachit\%, J.. Urban, Z., o Boyd, C. D. (2000). A quantitative evaluation of sage. Genome Research 10:1241-1248.

Takeuchi, K. e Collier, N. (2004). Bio-medical entity extraction using support vector machines. Artificial Intelligence in Medicine. Versão cletrônica disponivel em http://www.elsevierhealth.com/journals/aiim/.

'Tamayo, P., Slonim, D., Mesirov, J., Zhu, Q., Kitareewan, S., Dmitrovsky, E., Lander, E. S., c Golub, T. R. (1999). Interpreting patterns of gene expression with self-organizing maps. In Proc Natl Acad Sci USA, volume 96, pages 2907 2912. National Acadomy of Sciences.

Theodoridis, S. r Koutroumbas, K. (1999). Pattern Recognition. Acadomic Press, CA, USA, 1 odition.

'lu. Y. Stolovitzky, G. o Kilein, U. (2002). Quantitative noise analysis for gene expression microarray experiments. Proc Natl Acad Sci US A., 99(22):14031 6.

Vapnik, V. e Chapelle, O. (2000). Bounds on error expectation for support vector machines. Neural Computation, $12(9)$. 
Vapnik, V. c Chervonenkis, A. (1964). A note on one class of perceptrons. Automation e Remote Control, 25.

Vapnik, V. X. (1995). The nature of statistical learning theory. Springer-Verlag New York, Inc:

Velculescu, V. E., Zhang: L., Vogelstcin, B.. e Kinzler, K. W. (1995). Scrial analysis of gene expression. Science, 270:484 487.

Venter, C., Adams, M. D., Myers, E. W., e Li, P. W. (2001). The seqnence of the human genome. Science, 291:1304 1351. In Review.

Waghray, A., Foroze, F., Schober, M. S., Yao, F., Wood, C., Puravs, F., Krause, M., IIanash, S.. e Chen, Y. Q. (2001). Identification of androgen-regnlated genes in the prostate cancer coll line lncap by serial analysis of gene expression e proteomic analysis. Proteomics, 10:1615 9861.

Wahba, G. (1999). Support vector machine, reproducing kernel hilbert spaces o the randomized gacv. In B. Scholkopf, C. Burges, A. S., editor. Advances in Kernel MethodsSupport Vector Learning, Cambridge. MA. MIT press.

Wall, M. B. (1996). A Genetic Algorithm for Resource-Constrained Scheduling. Tese do doutorado, Department of Mechanical Engineering, Massachussetts Institute of Technology, Boston, MA.

West. M., Blanchette, C., Dressman, H., e Inuang, E. (2001). Predicting the clinical status of human breast cancer by using gene expression profiles. Proc Natl Acad Sci USA $98(20): 11462-7$.

Weston, .J., Elisseeff, A., BakIr, G., e Sinz, F. (2003a). PIDFR: object-orientuted machine learning library. Software available at http://www. kyb. tuebingen.mpg.de/bs/ people/spider/.

Weston, .J., Elisseeff, A., Sch\&\#246;lkopf. B., o Tipping, M. (2003b). Use of the zero norm with linear models e kernel methods. J. Mach. Learn. Res. 3:1439 1461.

Weston, J., Mukherjec, S., Chapclle, O., Pontil, M., Poggio, 'T., e Vapnik, V. (2000)). Fenture solection for SVMs. In NIPS, pages 668 674. 
Whitley, D. (1994). A genctic algorithm tutorial. Statistics e Computing, 4:65 85.

Wilcoxon, F. (1945). Individual comparisons by ranking methods. Biometrics, 1:80-83.

Witten, I. H. OFrank, E. (2000). Data Mining: Practical Machine Learning Tools $\mathrm{e}$ Technigues whth Jawa Implenentations. Morgan Kaufmam. San Francisen.

Wolfsberg, '1. G. e Landsman, D. (2001). Bioinformatics: A Practical Guide to the Analysis of Genes and Proteins. chapter Expressed Sequence Tags (EST'), pages 28.3 299. Wiley Interscience. New York, second edition elition.

Xing, F. P. (2003). Feature selection in microurray analysis. In Berrar, D., Dubitzky, W. r Granow, M., editors, Understanding e Using Microarray Analysis Techniques: A Prac:icial Guide, pages 110 131, Boston/Dordrecht/London. Kluwer Academic Publishers. 'To appoar.

Yang, J. e Honavar, V. G. (1998). Feature subset selection using a genetic algorithn. IEEE Intelligent Systems, 13(2):44 49.

Yang, Y. H., Buckley, M. J., Dudoit, S., e Speed, T. P. (2000). Comparison of methods for image analysis on cona microarray data. T'echnical Report 584, Department of Stanistics, University of California at Berkeley.

Yu, L. e Liu, H. (2004). Elticient feature sclection via analysis of relevance e redundancy Joumal of Machine Learning Research, 5:1205-1221.

Zhang, J. ( Liu, Y. (2002). Svm decision boundary based discrinuinative subspace induction. Technical Report cmu-ri-tr-02-15, Robotics Institute, Carnegic Mellon University.

Zhang, L., Zhou, W. Volculescu, V. E., Kern, S. E., Hruban, R. H., Hamilton, S. R., Vogelstein, 13.. e Kinzler, K. W. (1997). Gene expression profiles in normal e cancer cells. Science, $276: 1268-1272$.

Zheng, S., Jiu, I., e Tian, J. W. (2004). A new efficient svm-based edge detection method. Puttern Recognition Letters, 25(10):1143-1154. 